\title{
MECHANISTIC STUDIES ON THE PHOTOTOXICITY OF ROSUVASTATIN, ITRACONAZOLE AND IMATINIB
}

Directores:

Prof. Miguel Ángel Miranda Alonso

Dra. Virginie Lhiaubet-Vallet
Presentada por:

Giacomo Nardi 


\section{MECHANISTIC STUDIES ON THE PHOTOTOXICITY OF ROSUVASTATIN, ITRACONAZOLE AND IMATINIB}

PhD thesis of Giacomo Nardi (gnardi@itq.upv.es).

Most of the experiments have been carried out in ITQ (UPV-CSIC) laboratories under the direction of Prof. Miguel Angel Miranda and PhD Virginie Lhiaubet-Vallet ${ }^{1}$.

January 9, 2015

${ }^{1}$ Funding by Organon/Schering-Plough/MSD and Carlos III Institute of Health (PFIS FI09/00312) is gratefully acknowledged. 


\section{Certificación}

D. MIGUEL ÁNGEL MIRANDA ALONSO, Profesor Catedrático de Química de la Universitat Politècnica de València,

y

Dra. VIRGINIE LHIAUBET-VALLET, investigadora del Consejo Superior de Investigaciones cientifícas,

CERTIFICAN que la presente tesis doctoral, titulada "Estudios Mecanisticos

Sobre la Fototoxicidad de Rosuvastatina, Itraconazol e Imatinib", ha sido desarrollada por GIACOMO NARDI, bajo su dirección conjunta en el Instituto de Tecnología Química (UPV/CSIC).

Prof. Miguel A. Miranda Alonso

Dr. Virginie Lhiaubet-Vallet 
A mamma Angela, babbo Virgilio e Niccolò. A chi s'è allontanato e a chi, invece, mi ha raggiunto. 
Qué gran tónico sería para el novel observador el que su maestro, en vez de asombrarlo y desalentarlo con la sublimidad de las grandes empresas acabadas, le expusiera la génesis de cada invención científica, la serie de errores y titubeos que la precedieron, constitutivos, desde el punto de vista humano, de la verdadera explicación de cada descubrimiento! Tan hábil táctica pedagógica nos traería la convicción de que el descubridor, con ser un ingenio esclarecido y una poderosa voluntad, fue, al fin y al cabo, un hombre como todos. (SANTIAGo RAmón Y CAJAL, Reglas y consejos sobre investigación científica, Cap II)

Much of good science is opportunistic and revisionist. (GEORGE M. WhiteSIDES, Adv.Mater., 2004,16,1375) 


\section{Contents}

$\begin{array}{ll}\text { Contents } & \text { ix }\end{array}$

Abbreviations xiii

1 Introduction 1

1.1 Photosensitization by drugs . . . . . . . . . . . . . . 1

1.1.1 General photophysical concepts . . . . . . . . . . . . 1

1.1.2 Type I and Type II oxidation . . . . . . . . . . . . . . . 5

1.2 Principles of drug phototoxicity . . . . . . . . . . . . . . 7

1.2.1 Phototoxicity of statin drugs . . . . . . . . . . 8

1.2.2 Phototoxicity of halogenated nonsteroidal antiinflammatory

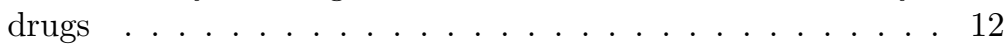

2 Aims 17

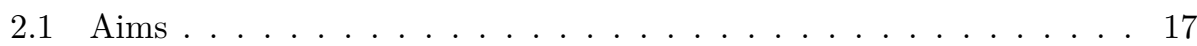

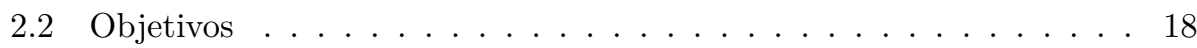

3 Phototoxicity of Rosuvastatin $\quad 19$

3.1 Introduction . . . . . . . . . . . . . . . . . . . 19

3.2 Results and discussion . . . . . . . . . . . . . . . . . . 21

3.2.1 Photophysics of rosuvastatin . . . . . . . . . . . . 21

3.2.2 Photophysics of the major rosuvastatin photoproduct . . . . 22

3.2.3 Interaction of ppRSV with biomolecules . . . . . . . . . 26

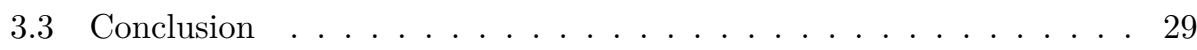

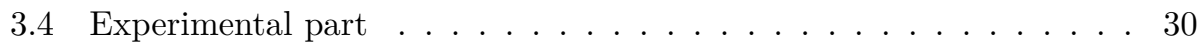

3.4 Chemicals .......................... 30

3.4.2 Photochemical synthesis of ppRSV . . . . . . . . . . 30

3.4.3 LFP experiments . . . . . . . . . . . . . . . . . . . . . . . . . . . . . . 30

3.4.4 Singlet oxygen measurements . . . . . . . . . . . . . . 31

3.4.5 EPR trapping experiments . . . . . . . . . . . . 31

3.4.6 Tryptophan photodegradation ............. 32 
4 Phototoxicity of Itraconazole 33

4.1 Introduction . . . . . . . . . . . . . . . . . . 33

4.1.1 Itraconazole and its photoadverse effects . . . . . . . . . 33

4.2 Results and discussion . . . . . . . . . . . . . . . . . . 35

4.2.1 Photophysical properties of itraconazole . . . . . . . . . 35

4.2.2 Photochemistry of itraconazole . . . . . . . . . . . 36

4.2.3 Type I photooxidation mediated by itraconazole . . . . . . . 40

4.2.4 Dyads as biomodels . . . . . . . . . . . . . . . 41

4.2.5 Photobinding of itraconazole to model biomolecules . . . . . 42

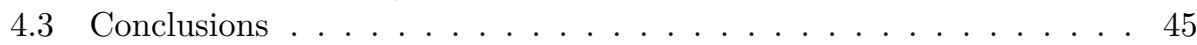

4.4 Experimental part . . . . . . . . . . . . . . . . . . . 45

4.4 Chemicals . . . . . . . . . . . . . . . 45

4.4 Photolysis of $1 \ldots \ldots \ldots \ldots$. . . . . . . . . . . . . . . . . . . 45

4.4.3 Isolation and identification of photoproducts $2-4 \ldots 46$

4.4.4 Synthesis of the model dyad 5 . . . . . . . . . . . 46

4.4.5 Isolation and identification of photoproduct $6 \ldots 46$

5 Photosensitization by Imatinib 49

5.1 Introduction . . . . . . . . . . . . . . . . . . . . . . . . . . . . . . . 59

5.2 Results and discussion ...................... 51

5.2.1 Photogenotoxicity of imatinib and its substructures . . . . . 51

5.2 .2 Photophysical studies . . . . . . . . . . . . . 51

5.3 Conclusions . . . . . . . . . . . . . . . . . 57

5.4 Experimental part . . . . . . . . . . . . . . . 57

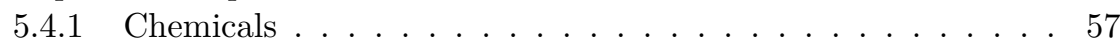

5.4 Agarose gels ...................... 57

6 Limitations of TEMPO/EPR method $\quad \mathbf{5 9}$

6.1 Introduction . . . . . . . . . . . . . . . . . . . 59

6.2 Results and discussion .................... 61

6.2.1 Determination of singlet oxygen quantum yield by TRNIR

or TEMPO/EPR . . . . . . . . . . . . . . . . 61

6.2.2 Effect of added TEMP on singlet oxygen detection by TRNIR 61

6.2.3 Quenching of photosensitizer excited states by TEMP . . . . 62

6.2.4 Electron transfer oxidation of TEMP to TEMPO . . . . . . . 65

6.2.5 The case of rose Bengal, an archetypal ${ }^{1} \mathrm{O}_{2}$ photosensitizer . 65

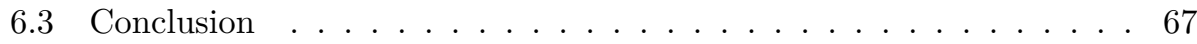

6.4 Experimental part . . . . . . . . . . . . . . . 67

6.4.1 Chemicals ............................. 67

6.4.2 Steady state fluorescence quenching . . . . . . . . . . . 67

6.4.3 Fluorescence lifetimes . . . . . . . . . . . . . . 68

6.4.4 Singlet oxygen time-resolved near infrared (TRNIR) emission measurements . . . . . . . . . . . . . . 68

6.4.5 EPR trapping measurements ............. . . 68

6.4.6 Photoinduced electron transfer . . . . . . . . . . . . 69 
7 General experimental procedures $\quad 71$

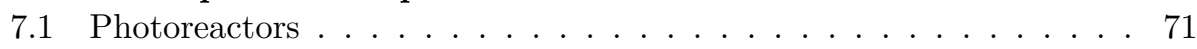

7.2 UV-Vis absorption spectroscopy . . . . . . . . . . . . . . . 71

7.3 Fluorescence and phosphorescence emissions . . . . . . . . . . . . 71

7.4 Laser flash photolysis (LFP) . . . . . . . . . . . . . . . . . . . . . 72

7.5 Singlet oxygen measurements . . . . . . . . . . . . . . . . 72

7.5.1 ITQ (UPV-CSIC) system, used in chapter $3 \ldots . . . . . .72$

7.5.2 ISOF-CNR system, used in chapter $6 \ldots . . \ldots 73$

7.6 NMR and HRMS spectroscopic characterization . . . . . . . . . 73

8 Summaries $\quad \mathbf{7 5}$

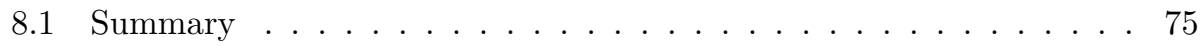

8.2 Resumen. . . . . . . . . . . . . . . . . . 78

8.3 Resum . . . . . . . . . . . . . . . . . 81

9 General conclusions $\quad 85$

$\begin{array}{lr}\text { A appendix chapter } 4 & \mathbf{8 9}\end{array}$

A.1 Itraconazole . . . . . . . . . . . . . . . . . . . . . . . . . 89

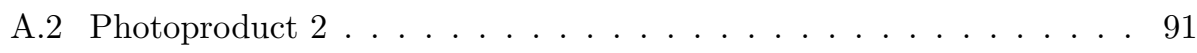

A.3 Photoproduct $3 \ldots \ldots \ldots \ldots$. . . . . . . . . . . . . . . . . . . . . . .

A.4 Photoproduct $4 \ldots \ldots \ldots \ldots \ldots$. . . . . . . . . . . . . . . . . . . . . . . .

A.5 Model dyad $5 \ldots \ldots \ldots \ldots$. . . . . . . . . . . . . . . . . . . . . . . . . . . . . . . . .

A.6 Model dyad $6 \ldots \ldots$. . . . . . . . . . . . . . . . . 97

$\begin{array}{lr}\text { B appendix chapter } 5 & 101\end{array}$

B.1 2-phenylaminopyrimidine $(1) \ldots \ldots$. . . . . . . . . . . . . . . . . . . . 101

B.2 4-(Pyridin-2-yl)-2-aminopyrimidine (2) . . . . . . . . . . . . . . 102

B.3 N-(3-aminophenyl)benzamide (3) . . . . . . . . . . . . . . . . 104

$\begin{array}{ll}C \text { appendix chapter } 6 & 107\end{array}$

$\begin{array}{ll}\text { D Publications } & 111\end{array}$

$\begin{array}{ll}\text { Bibliography } & 111\end{array}$

$\begin{array}{lr}\text { List of Figures } & 123\end{array}$

$\begin{array}{lr}\text { List of Tables } & 129\end{array}$

$\begin{array}{ll}\text { Acknowledgement } & 130\end{array}$ 


\section{Abbreviations}

- Abl: Abelson cytoplasmic tyrosine kinase

- ACN: Acetonitrile

- ATV: Atorvastatin

- ppATV: Atorvastatin photoproduct

- BAHA: Tris(4-bromophenyl)aminium hexachloroantimonate

- $\beta \mathrm{C}: \beta$-carotene

- BP: Benzophenone

- CBZ: Carbazole

- Ch: Cholesterol

- CML: Chronic myeloid leukemia

- CRP: Carprofen

- ppCRP: Carprofen photoproduct

- DCF: Diclofenac

- ppDCF: Diclofenac photoproduct

- EPR: Electron paramagnetic resonance

- GIST: Gastrointestinal stromal tumors

- HMGR: HMG-CoA reductase or 3-hydroxy-3-methyl-glutaryl-CoA reductase

- HSA: Human serum albumin

- HPLC: High performance liquid chromatography

- $\mathrm{IC}_{50}$ : Half maximal inhibitory concentration

- IMT: Imatinib 
- ITZ: Itraconazole

- KP: Ketoprofen

- LFP: Laser flash photolysis

- MDPA: Methyldiphenylamine

- MeOH: Methanol

- NSAID: Nonsteroidal anti-inflammatory drug

- NP: Naphthalene

- MeNP: 1-methylnaphthalene

- PBS: Phosphate buffered saline solution

- PDGFR: Platelet derived growth factor receptors

- PET: Photoinduced electron transfer

- PN: Phenalenone o perinaphthenone

- RSV: Rosuvastatin

- ppRSV: Rosuvastatin photoproduct

- SSB: Single strand break

- TEMP: 2,2,6,6-tetramethylpiperidine

- TEMPO: 2,2,6,6-tetramethyl-1-piperidinyloxyl

- Thd: Thymidine

- TRNIR: Time resolved near infrared

- Trp: L-tryptophan

- UVA: Ultraviolet A light

- UVB: Ultraviolet B light

- UVC: Utraviolet C light -

- UV-Vis: Ultraviolet-Visible light 


\section{Chapter 1}

\section{Introduction}

\subsection{Photosensitization by drugs}

\subsubsection{General photophysical concepts}

\section{Electronic states and excitation of organic molecules}

Organic photochemistry is a science concerned with the processes that result from interaction of light with organic molecules [1]. The functional group responsible for light absorption is denominated chromophore, thus it represents the substructure of an organic molecule that is primarily responsible for its photochemical activity.

From a fundamental point of view, photochemistry is a matter of molecular orbitals, which originate from the overlap of atomic $s$ and $p$ orbitals. They are classified into three main classes, bonding $(\sigma$ or $\pi)$, antibonding $\left(\sigma^{*}\right.$ or $\left.\pi^{*}\right)$ and nonbonding orbitals $(n)$. Most organic molecules are closed-shell molecules, in which the highest occupied molecular orbitals (HOMOs) are bonding $\sigma, \pi$ or nonbonding $n$ orbitals. Upon excitation, an electron of the chromophore may be promoted into the lowest unoccupied molecular orbital (LUMO), which is usually an antibonding $\sigma^{*}$ or $\pi^{*}$ orbital. Thus, most frequent excitations of organic molecule chromophores are:

- $\pi \rightarrow \pi^{*}$, exhibited by alkenes, alkynes and aromatic molecules

- $n \rightarrow \pi^{*}$, exhibited by compounds containing carbonyl, thiocarbonyl, nitro, azo and imin groups

- $n \rightarrow \sigma^{*}$, exhibited by amines, alcohols and haloalkanes

Each electron in a molecule carries a spin angular momentum with a spin quantum number $s=1 / 2$, it can take one of two orientations:

- Spin up: $\uparrow$ or $\alpha$ 
- Spin down: $\downarrow$ or $\beta$

The total spin angular momentum of a molecule is represented by the total spin quantum number $\mathrm{S}$, which is the vector sum of electron spin quantum number. If spins are opposite, the sum is 0 , if they are parallel is it 1 . The spin multiplicity is given by $2 \mathrm{~S}+1$.

In the ground electronic state of most organic molecules, all electrons are spinpaired, thus it means that $\mathrm{S}=0$ and spin multiplicity is 1 . This condition is called singlet state and is abbreviated as $\mathrm{S}_{0}$.

After the light absorption, an electron is promoted to an antibonding orbital:

- if electrons are still paired, the total spin quantum number is zero, so this state corresponds still to a singlet state abbreviated as $\mathrm{S}_{1}$.

- If electrons are aligned in parallel $\mathrm{S}=1$ and the spin multiplicity is 3 . This condition is called triplet state and is abbreviated as $\mathrm{T}_{1}$.

The energy of triplet state is generally lower than that of singlet state. The reason is the fact that the repulsion between two electrons occupying different orbitals is minimized if their spins are opposed.

For most organic molecules excited from their ground state, preservation of the spin multiplicity favors singlet-singlet transitions and forbids singlet-triplet transition. In spite of this, coupling between electronic and nuclear motion enables some symmetry-forbidden transitions to become weakly allowed.

\section{Deactivation of excited molecules}

The electronically excited molecules are energetically unstable with regard to the ground state. Consequently molecules could rearrange or fragment (photochemistry) or loose their excitation energy to return to the ground state (photophysics). Three deactivation pathways are possible (Figure 1.1):

- Radiative processes: emission of an electromagnetic radiation (fluorescence and phosphorescence).

- Nonradiative processes: nonradiative transition to another electronic state.

- Quenching processes: deactivation by collision with another molecule.

In the first case, the emitted light has a longer wavelength, thus a lower energy, than the absorbed radiation. Fluorescence is the emission that occurs from an excited state with the same spin multiplicity than the ground state (usually from $\mathrm{S}_{1}$ to $\mathrm{S}_{0}$ ). As absorption, fluorescence is strongly allowed, for that reason it takes place on fast timescale from picoseconds to microseconds. Phosphorescence emission is originated during the deactivation of an excited state of spin multiplicity different from that of the ground state (for example $\mathrm{T}_{1} \rightarrow \mathrm{S}_{0}$ ). Its timescale is 


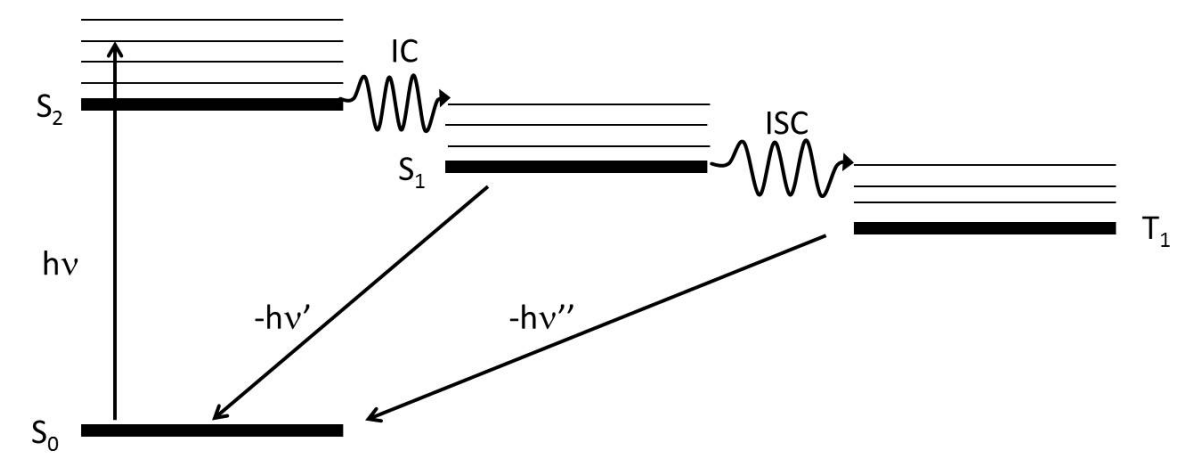

Figure 1.1: The Jablonski diagram, where $h \nu$ : absortion, - $h \nu$ ': fluorescence, - $h \nu$ ": phosphorescence, IC: internal conversion, ISC: intersystem crossing.

of milliseconds to seconds.

Nonradiative transition is defined by an intramolecular process that involves a conversion, at a constant energy, from one state to another one. The latter is produced with some excess of vibrational energy and relaxes rapidly by releasing heat. Radiationless transitions can correspond to:

- Internal Conversion (IC) when it involves electronic state of the same spin multiplicity (for example $\mathrm{S}_{2} \rightarrow \mathrm{S}_{1}$ ).

- Intersystem Crossing (ISC) when it involves electronic states of different spin multiplicity (for example $\mathrm{S}_{1} \rightarrow \mathrm{T}_{1}$ ).

In the quenching process, the de-excitation of the excited molecule is performed by another molecule called quencher. This bimolecular process is followed by the decrease of the excited molecule concentration. In the next section, details of two quenching processes are exposed.

\section{Electronic energy transfer and photoinducted electron transfer}

Electronic energy transfer (ET) is defined by the IUPAC as the photophysical process in which an excited state of one molecular entity (the donor, M) is deactivated to a lower-lying state by transferring energy to a second molecular entity (the acceptor, Q) which is thereby raised to a higher energy state. Thus, the reaction may be written as follows:

$$
M^{*}+Q \rightarrow M+Q^{*}
$$

where, the initially excited $\mathrm{M}^{*}$ transfers energy to a suitable acceptor molecule (Q) with energy levels near or below the energy level of the donor. This results in the simultaneous quenching of $\mathrm{M}^{*}$ and excitation of $\mathrm{Q}$. The species $\mathrm{Q}^{*}$, indirectly excited, can then undergo various photochemical and photophysical processes, such 
processes are called photosensitized reactions.

Depending on spin multiplicity of $\mathrm{M}$ and $\mathrm{Q}$ various energy transfer processes can occur (singlet-singlet, triplet-triplet). Here, the attention has been centered in the process studied in the experimental work of this thesis: the triplet-triplet energy transfer (TTET), $\mathrm{M}_{T 1}^{*}+\mathrm{Q}_{S 0} \rightarrow \mathrm{M}_{S 0}+\mathrm{Q} *_{T 1}$. This processes is a quite common method to produce triplet state when a molecule has a low ISC quantum yield. In this context, the $\mathrm{Q}$ triplet state could not be produced in high yield by direct excitation, and thus $\mathrm{M}$ is used as a photosensitizer. The efficiency of TTET depends on the energy gap between the triplet excited state energies of $\mathrm{M}$ and Q. Indeed, the bimolecular rate constant of this process $\left(k_{T T}\right)$ can be determined by using the Sandros equation (Eq.1.2), which takes into account the triplet energies of $\mathrm{M}^{*}$ $\left(\mathrm{E}_{T}^{M *}\right)$ and $\mathrm{Q}\left(\mathrm{E}_{T}^{Q *}\right)$, and the diffusion rate constant of the medium $\left(k_{d i f f}\right)[2]$.

$$
k_{T T}=k_{d i f f} /\left(1+\exp \left(-\left(E_{T}^{M *}-E_{T}^{Q *}\right) / R T\right)\right)
$$

Formation of singlet oxygen is also a photosensitized process, which generally occurs by quenching of triplet excited state of the donor by molecular oxygen $\mathrm{O}_{2}$ : $\mathrm{M}^{*}{ }_{T 1}+\mathrm{Q}_{T 0} \rightarrow \mathrm{M}_{S 0}+\mathrm{Q}^{*}{ }_{S 1}$. It is noteworthy that the ground state of molecular oxygen is a triplet state, which after sensitization is activated to its singlet state, giving rise to the so-called singlet oxygen. Indeed, molecular oxygen has the highest electrons unpaired (with the same spin) in the degenerated $\pi^{*}{ }_{x}$ and $\pi^{*} y$ orbitals, so into ground state molecular oxygen is a triplet state $\left({ }^{3} \Sigma_{u}\right)$. Upon excitation, the electrons become paired, so the excited oxygen is a singlet state ${ }^{1} \Delta_{g}$ or ${ }^{1} \mathrm{O}_{2}$. As explained above, this process is spin forbidden, so ${ }^{1} \mathrm{O}_{2}$ is obtained through energy transfer generally from a triplet excited state, although some cases of singlet excited state sensitization also exist.

Electronically excited state molecules are more potent electron acceptors or donors compared to the ground state. Photoinducted electron transfer (PET) is an excited state electron transfer process by which an electron is transferred from the donor to the acceptor. This reaction is favored in polar solvent, which is able to solvate better charged species allowing a better charge separation. Depending on the redox properties of both species, two processes are possible:

- $\mathrm{M}^{*}+\mathrm{Q} \rightarrow{ }^{+\bullet} \mathrm{M}+\mathrm{Q}^{-\bullet}:$ reductive quenching

- $\mathrm{M}^{*}+\mathrm{Q} \rightarrow{ }^{-\bullet} \mathrm{M}+\mathrm{Q}^{+\bullet}$ : oxidative quenching

Taking the oxidative quenching as example, the thermodynamics of the reaction can be determined by the Rehm-Weller equation [3]:

$$
\Delta G^{0}=E_{0}\left(Q / Q^{+\bullet}\right)-E_{0}\left(M^{-\bullet} / M^{*}\right)
$$

Where $\Delta G^{0}$ is the free energy changes of the photoreaction, $E_{0}\left(Q / Q^{+\bullet}\right)$ the oxidation potential of $\mathrm{Q}$ in its ground state and $E_{0}\left(M^{-\bullet} / M^{*}\right)$ the reduction potential of $\mathrm{M}$ in its excited state.

As the latter can be expressed as $E_{0}\left(M^{-\bullet} / M^{*}\right)=E_{0}\left(M^{-\bullet} / M\right)-\Delta \mathrm{E}_{0-0}$, equation 1.3 can be converted into: 


$$
\Delta G^{0}=E\left(Q / Q^{+\bullet}\right)-E\left(M^{-\bullet} / M\right)-\Delta E_{0-0}
$$

\subsubsection{Type I and Type II oxidation}

Photosensitized reactions are classified into two processes called Type I and Type II. It has been generally recognized that the triplet state of the photosensitizer is generally the key species in such processes (Figure 1.2). In this context, it is considered as the biologically active intermediate because of its central role in biomolecule sensitization. In the Type I reaction, the excited photosensitizer reacts directly with the substrate, by electron transfer or hydrogen abstraction, to produce radical ions or neutral radicals. Although electron transfer can proceed in either direction, usually the biological substrate donates an electron to the sensitizer, resulting in a substrate radical cation $\left(\mathrm{Sub}^{\bullet+}\right)$, and a sensitizer radical anion $\left(\mathrm{Sen}^{\bullet-}\right)$. At this stage, $\mathrm{Sen}^{\bullet-}$ can transfer an electron to molecular oxygen to produce the superoxide radical anion $\left(\mathrm{O}_{2}{ }^{\bullet-}\right)$, and regenerate the original sensitizer. In the Type II mechanism, the excited sensitizer transfers its energy to molecular oxygen giving rise to the reactive singlet oxygen, and regenerating the ground-state sensitizer. Singlet oxygen then reacts with the substrate to generate oxidized products. Generally the photosensitizer is not consumed during this type of reaction, unless it reacts with ${ }^{1} \mathrm{O}_{2}$.

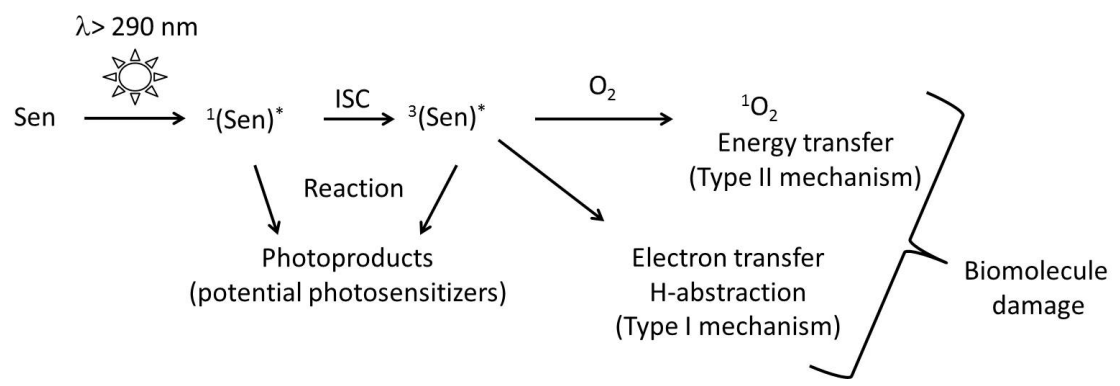

Figure 1.2: Mechanistic pathways involved in the photosensitization processes of biomolecules. Figure redrawn from reference [4]

Lipids, proteins and DNA are substrates of Type I sensitization [5-7]. It should be underlined that the amino acids or DNA nucleobases with the lowest oxidation potential are the main target during the electron transfer process. These substrates are guanine for DNA (Figure 1.3) and tyrosine or tryptophan for proteins.

Concerning the Type II processes with lipids, addition of the highly electrophilic singlet oxygen to the double bonds of unsaturated fatty acids generates hydroperoxides (Figure 1.4)[6]. In the case of proteins, tryptophan and histidine are the most reactive amino acids and their oxidation also results in the formation of hydroperoxides as shown in Figure 1.5 [7]. The production of modified proteins as a result of ${ }^{1} \mathrm{O}_{2}$-mediated photooxidation can promote a wide range of 
$\overbrace{\mathrm{R}}^{\mathrm{N}_{\mathrm{NH}}}$

$$
\mathrm{H}_{2} \mathrm{O} \downarrow-\mathrm{H}^{+}
$$

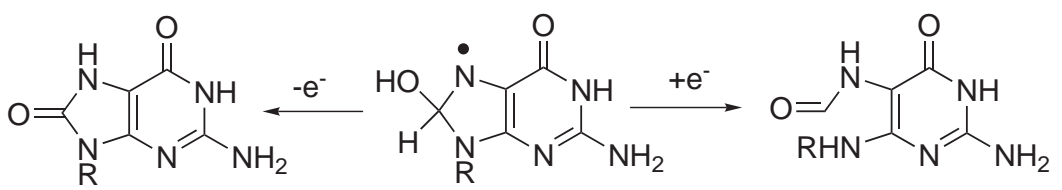

Figure 1.3: One electron oxidation of guanine nucleobase. $R$ is the DNA chain

biophysical and biochemical changes in both the properties and functions of proteins: increased or decreased susceptibility to proteolytic enzymes, modifications in mechanical properties and changes in binding of co-factors and metal ions. This may have major effects on cellular function, the inhibition of key cellular enzymes and the potential induction of DNA damage, suggesting that these species may be key intermediates in cellular dysfunction and disease progression.

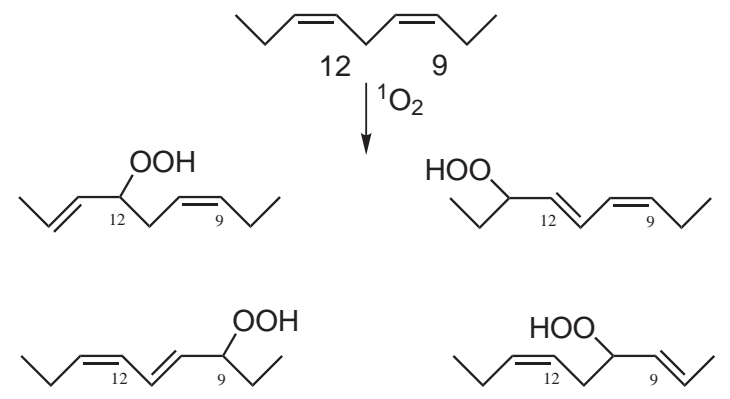

Figure 1.4: Photooxidation of methyl linoleate

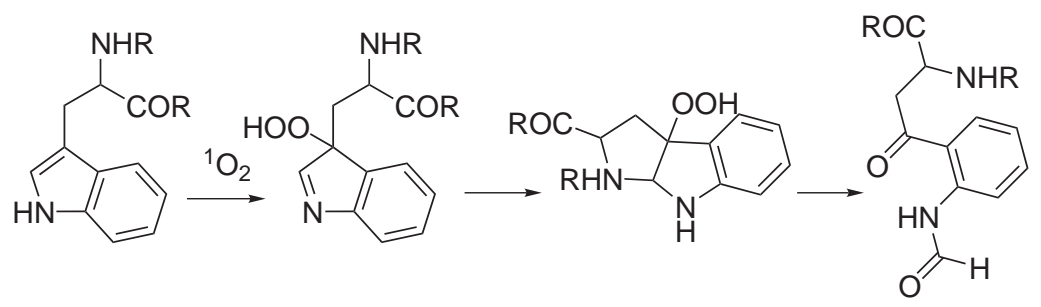

Figure 1.5: Reaction of ${ }^{1} \mathrm{O}_{2}$ with Trp. $R$ is the protein chain 
Unless the DNA four bases are in principle susceptible to be oxidized by singlet oxygen, reaction only occurs with 2'-deoxyguanosine giving rise to 8-oxo-7,8dihydro-2'-deoxyguanosine (8-oxodG, Figure 1.6). This compound reacts even easier with ${ }^{1} \mathrm{O}_{2}$ leading to further oxidized photoproducts. Formation of these damages gives rise to abasic sites in DNA together with single and double DNA strand breaks and can ultimately result in G-T transversions. [5]

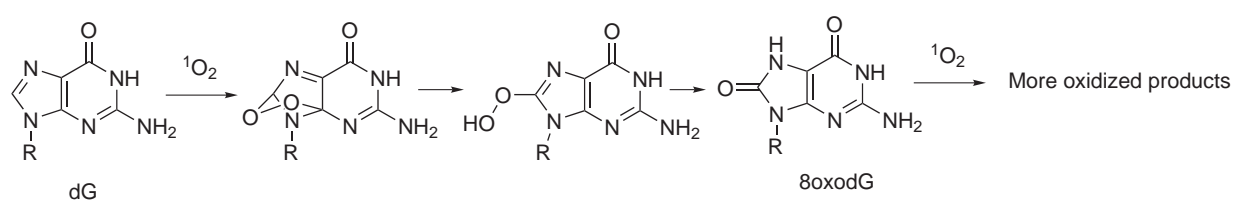

Figure 1.6: Main oxidation product produced by the reaction of ${ }^{1} \mathrm{O}_{2}$ with the guanine moiety.

\subsection{Principles of drug phototoxicity}

Ultraviolet solar radiation reaching the earth surface corresponds predominantly to UVA radiation as the portion of UVB represents less than $5 \%$. While UVC $(100-290 \mathrm{~nm})$ is totally absorbed by the atmosphere, UVB $(290-320 \mathrm{~nm})$ cannot penetrate beyond the superficial skin layers but is biologically active (vitamin D photosynthesis, local and systemic immunosuppression). Concerning the UVA (320-400 nm), it is not significantly filtered by the atmosphere and can penetrate into the deeper layers of the skin; but, however, it is only scarcely absorbed directly by the biomacromolecules. In spite of this, UVA is able to activate chemicals (ie. photosensitizers) extending the range of biologically relevant UV light and triggering indirectly biological damage. Sunlight exposure could lead to severe skin reactions: erythema, pruritus, urticaria etc..., but also to skin cancers like squamous and basal cell carcinoma or even melanoma. In this context, it has been evidenced that melanoma skin cancer is directly associated with sunlight exposure. In Europe, its incidence has largely increased since 1975. It is the $5^{\text {th }}$ most commonly diagnosed cancer with 82100 cases in 2012 and a mortality of 15700 cases [8]. Furthermore, an important issue of healthcare relies on the photosensitizing effect of xenobiotics since modern lifestyle often associates sunlight exposure with the presence of chemical substances in the skin (daily life chemicals like perfumes, sunscreen components and therapeutic agents). Photosensitization is identified by the development of abnormal cutaneous reactions triggered by sunlight doses regarded as harmless, most often in the UVA range. Thus, a photosensitizing compound, generally not toxic by itself, becomes reactive under irradiation [9]. Photosensitivity induced by xenobiotics is divided into two phenomena: phototoxicity and photoallergy. Phototoxicity can be elicited by a wide range of agents (but also by their metabolites or photoproducts). The reaction is essentially immediate and resembles an exaggerated sunburn. Phototoxic reactions are much more prevalent than photoallergic ones. They depend on the light dose received and on the photosensitizer concentration in the skin. Moreover, they exhibit a maximum in- 
tensity early after UV exposure, followed by a decrescendo evolution within 24-72 h. Eruptions occur only on exposed skin areas and the lesions are characterized by erythema, infiltration, edema, or blisters, followed by desquamation and hyperpigmentation. It has also been suggested that repeated phototoxic reactions have the potential to increase the already high risk of skin cancer from sunburn [4]. By contrast, photoallergy is uncommon and immunologically mediated and requires previous exposure to the photosensitizing agent and an induction period. Clinically, it is very similar to contact allergic reactions, with a delayed onset and a crescendo reaction pattern. Photoallergic contact dermatitis may generally affect well defined areas exposed to sunlight, but it may extend to other parts of the body, sometimes distant from the initially affected area. The corresponding skin lesions are erythema, infiltration, papulovesicles, erosions, or bullae. The molecular mechanism completely differs from that of phototoxicity; the irradiated drug (metabolite or photoproduct) plays the role of a photohapten, which can covalently bind to a carrier protein (photobinding), giving rise to a photoantigen able to trigger the immunological process.

A mechanistically based approach taking into account the sensitizer photophysical and photochemical properties has to be considered for a deeper understanding of the molecular processes involved in the photosensitivity side effects. Indeed, the primary characteristic for a compound to be considered a potential photosensitizing agent is the absorption in the UVA-UVB and visible range $(\lambda>290$ $\mathrm{nm})$. Upon excitation, the molecule reaches a singlet excited state, which can cross to the triplet excited state. This latter has been recognized as the key intermediate responsible for most of the biomolecule damage formation through Type I/II mechanisms or triplet-triplet energy transfer.

\subsubsection{Phototoxicity of statin drugs}

As explained above, photosensitizing effects of xenobiotics are of increasing concern in dermatology. This section is focused on statin drugs, which are the most prescribed hypolipemiants in Europe and in the USA (with annual sales in excess of $\$ 22$ billion). These lipid-lowering agents act in an early and rate-limiting step of cholesterol biosynthesis by competitive inhibition of 3-hydroxy-3-methylglutarylcoenzyme A (HMG-CoA) reductase, an enzyme that catalyzes the conversion of HMG-CoA to mevalonate by NADPH as reductor (Figure 1.7). Specifically, the bulky and hydrophobic moiety of statins fills the HMG-binding pocket and part of the binding surface of coenzyme A (CoA). This interaction prevents the access of HMG-CoA to HMG reductase [10].

Interestingly, several clinical cases of cutaneous reactions have been reported and associated with photosensivity disorders [11-17]. As example, it can be mentioned: eruptions, dermatitis, porphyria cutanea, chronic actinic dermatitis, cutaneous lupus erythematosus.

Indeed, two different mechanisms have been suggested to explain the molecular basis of the statin sensitization process. The first one does not require light 

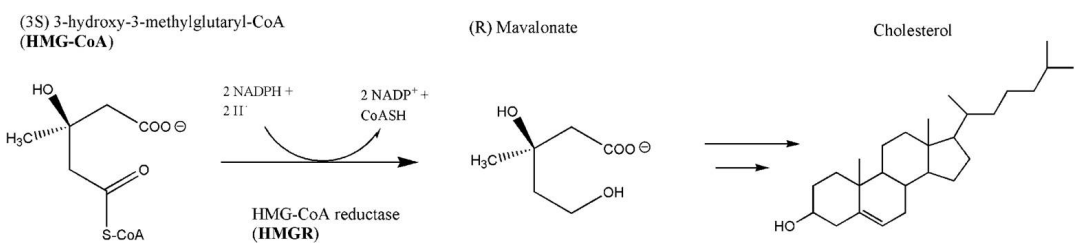

Figure 1.7: Step of the biosynthesis of isoprenoids and sterols inhibited by statins: the fourelectron reductive deacylation of $H M G-C o A$ to coenzyme $A$ and mevalonate.

absorption by the drug and deals with drug alteration of the cell metabolism, which finally triggers the photosensitivity. This scenario has been proposed to account for the photosensitivity induced by lovastatin (Figure 1.8), which in spite of its lack of absorbance above $280 \mathrm{~nm}$ has been shown to be responsible for an enhancement of keratinocyte cellular damage under UVA-irradiation (Table 1.1)[18, 19]. Indeed, it has been advanced that this HMG-CoA inhibitor produces an alteration of cholesterol cell content, which results in a higher sensitivity under UVA-irradiation.<smiles>CC(C)N1C(/C=C/C(O)C[C@H](O)CC(=O)O)=C(c2ccc(F)cc2)C2C=CC=CC21</smiles>

Fluvastatin<smiles>CC(C)N1c2ccc3cc(F)ccc3c2C2C=CC=CC21</smiles>

Fluvastatin photoproduct<smiles>CCC(C)C(=O)O[C@H]1C[C@@H](C)C=C2C=C[C@H](C)C(CCC3CC(O)CC(=O)O3)C21</smiles>

Figure 1.8: Structures of Lovastatin, Fluvastatin and Fluvastatin photoproduct

The second mechanism is based on drug photolability and puts foward that, upon light absorption, the phototoxic effect of statins is not mediated by the parent drug but by one of its photoproducts. An interesting case relies on the phototoxic potential of fluvastatin (Figure 1.8), which has been established by in vitro studies of UVA-irradiated human keratinocytes and 3T3 fibroblasts. One of fluvastatin photoproducts (Figure 1.8), a benzocarbazole-like compound, has been revealed to 


\begin{tabular}{ccc} 
& \multicolumn{2}{c}{ Cell viability $(\%)$} \\
\hline & No irradiated & Irradiated \\
\hline Control & 100 & 79 \\
Lovastatin & 97 & 22 \\
Lovastatin + cholesterol & 97 & 77 \\
Lovastatin + LDL protein & 96 & 72
\end{tabular}

Table 1.1: Effect of Lovastatin (alone or with protectors) on the 24h UVA-induced photocytotoxicity in cultured human cell. Table modified from ref[18]

be a more effcient photosensitizer than the parent drug. Specifically, the enhancement of intracellular calcium, lipid membrane peroxidation and oxidation of model proteins (BSA, HSA) and RNASe suggests that fluvastatin and its photoproduct affect mainly the cellular membrane by photosensitization (Figure 1.9) [20].

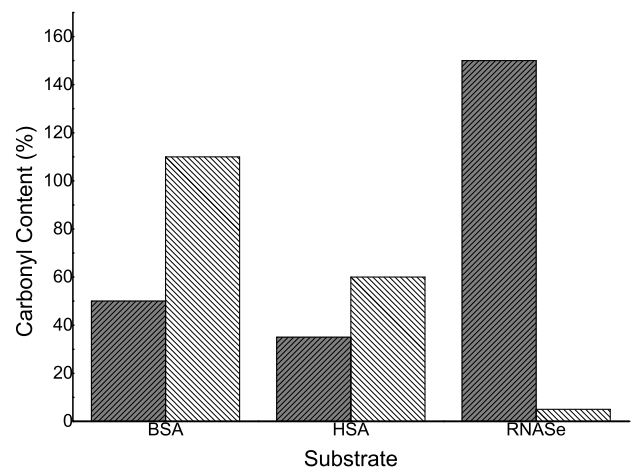

Figure 1.9: Photosensitized protein oxidation by fluvastatin (grey) and its photoproduct (white) at $11 \mathrm{~J} \mathrm{~cm}^{-2} \mathrm{UVA}$, and $10 \mu \mathrm{M}$ of photosensitizer, monitored as carbonyl content. Figure from reference [20]

In an earlier work, similar conclusions have been drawn in our group from photochemical and photobiological studies of atorvastatin calcium (ATV, Figure 1.10). This statin agent of the second generation is one of the most frequently prescribed drugs in the United States and in Europe. Natural sunlight irradiation of ATV aqueous solution leads mainly to a photoproduct resulting from oxidation of the pyrrole ring and cyclization of the stilbene-like structure of ATV to form the phenanthrene derivative ppATV (Figure 1.10)[21].

The absence of a triplet-triplet absorption in ATV, revealed by laser flash photolysis (LFP), discards the role of the parent drug as photosensitizer. By contrast, ppATV exhibits a triplet-triplet transient absorption at $\lambda_{\max }=460 \mathrm{~nm}$ with a lifetime of $26 \mu \mathrm{s}$ (Figure 1.11)[22].

This species is quenched by Trp giving rise to the formation of the tryptophanyl radical derived from a Type I oxidation of the amino acid. Moreover, this photo- 


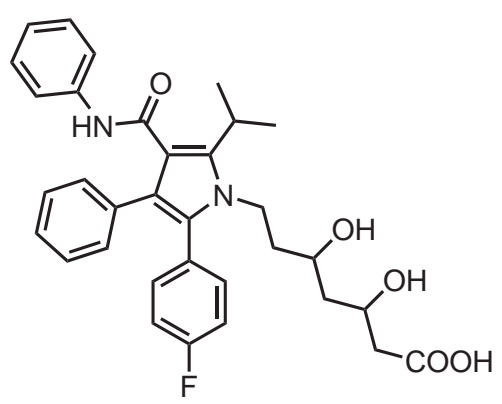

ATV<smiles>CC(C)C1(C(=O)Nc2ccccc2)C(=O)N(CCC(O)CC(O)CC(=O)O)c2c1c1ccccc1c1cc(F)ccc21</smiles>

PpATV

Figure 1.10: Structures of $\mathbf{A T V}$ and ppATV

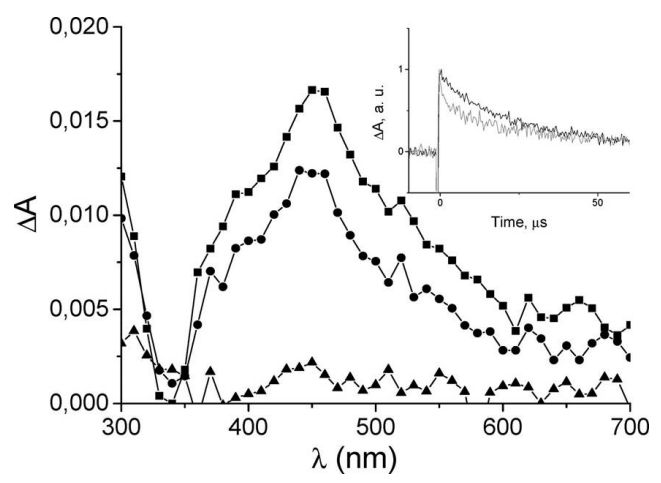

Figure 1.11: Transient absorption spectrum of a deaerated methanolic solution of ppATV after laser pulse from 5 to $50 \mu \mathrm{s}$. Inset: Normalized decay monitored at $450 \mathrm{~nm}$ of the transient obtained with nitrogen-bubbled (black line) or aerated (gray line) solutions of ppATV. Adapted from reference [22]

product is able to produce singlet oxygen as observed by electron paramagnetic resonance (EPR) using TEMP as ${ }^{1} \mathrm{O}_{2}$ trap (see also Chapter 6 for accurate use of the TEMPO/EPR methodology). During this experiment, the typical TEMPO signal is increasing steadily for irradiation in the presence of $\mathbf{p p A T V}$, while an induction time is necessary in the case of ATV. This is in agreement with the inability of ATV itself to act as singlet oxygen sensitizer. The longer irradiation times, the increase of TEMPO signal can be explained by the photochemical conversion of the drug into ppATV; thus, this compound may behave as a Type I and/or Type II photosensitizer (Figure 1.12)[22].

From a photobiological point of view, processes involved in biomolecule photosensitization by ppATV have been established using tryptophan (Trp) as model biological component because it can be oxidized both by Type I and Type II mechanisms. The time-dependent decrease of Trp fluorescence emission upon UVAirradiation in the presence of ppATV is in agreement with the amino acid degra- 


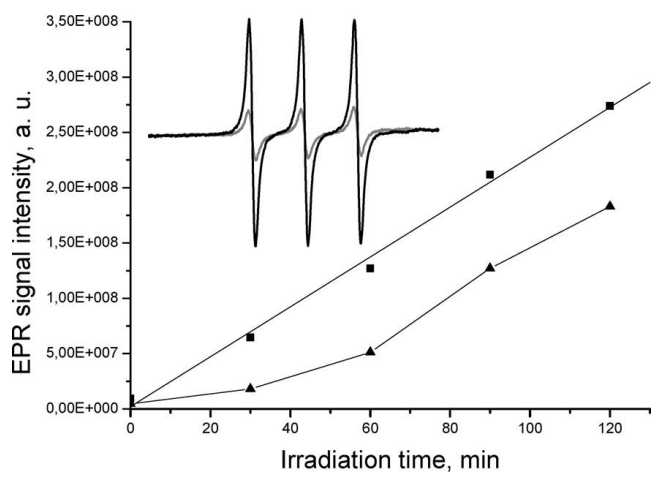

Figure 1.12: Time-dependent formation of TEMPO upon irradiation of aerated solutions of TEMP in the presence of $\boldsymbol{A T V}(\triangle)$ or $\boldsymbol{p p} \boldsymbol{A T V}(\mathbf{\square})$. Inset: TEMPO signals obtained after $30 \mathrm{~min}$ of irradiation of a solution of $\boldsymbol{A T V}$ (gray line) and ppATV(black line).Adapted from reference [22]

dation. Moreover, the involvement of a type II mechanism is evidenced by the significant enhancement of the reaction rate when the experiment is performed in $\mathrm{D}_{2} \mathrm{O}$, where ${ }^{1} \mathrm{O}_{2}$ presents a much longer lifetime in comparison with water (Figure 1.13) $[22]$.

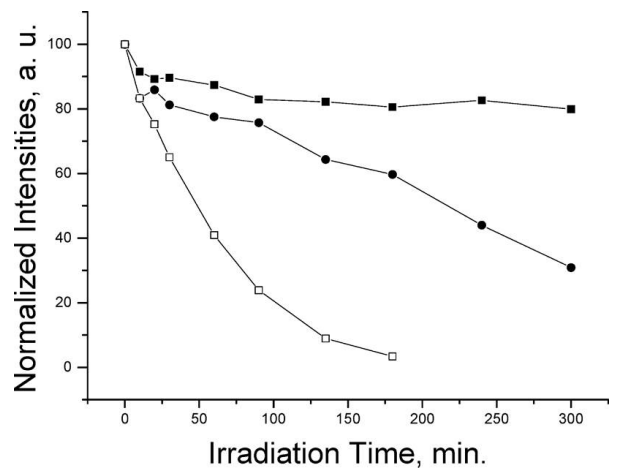

Figure 1.13: Tryptophan photodegradation monitored as function of irradiation time: tryptophan alone $(\mathbf{\square})$, tryptophan and $\boldsymbol{p p} \boldsymbol{A T} \boldsymbol{T} \boldsymbol{V}$ in water $(\bullet)$, and tryptophan and $\mathbf{p p} \boldsymbol{A T \boldsymbol { V }}$ in deuterium oxide as solvent ( $\square$ ). Adapted from reference [22]

\subsubsection{Phototoxicity of halogenated nonsteroidal antiinflam- matory drugs}

In this section, the photosensitivity induced by aryl radicals is presented through the photoreactivity of carbazole derivatives. Two studies on nonsteroidal antiinflammatory drugs (NSAID) are selected as examples. The first one deals with phototoxicity of carprofen (CRP) based on the reactive aryl radical obtained directly upon irradiation of the parent drug. The second example is centered on diclofenac (DCF), whose photoreactivity toward biological components is ascribed 
to its photoproduct, which is in the origin of an aryl radical formation.

Photochemical studies performed on CRP shows that it suffers a dehalogenation process leading to 2-(2-carbazolyl)propionic acid (ppCRP) as main photoproduct (Figure 1.14) [23].

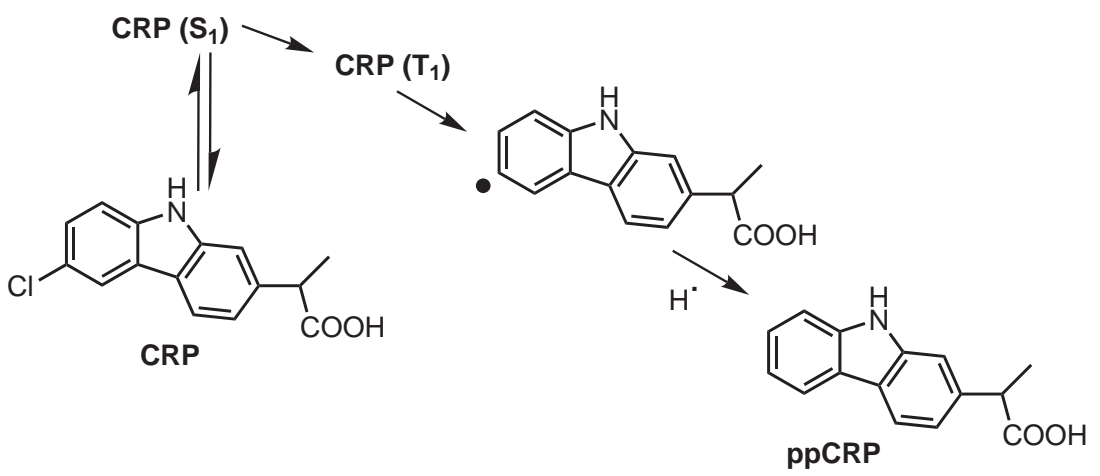

Figure 1.14: Photophysical and photochemical pathways of carprofen. Figure redrawn from reference [23]

Kinetic studies performed by LFP shows that this process mainly occurs from CRP triplet excited state, which exhibits a triplet-triplet absorption band at $\lambda_{\max }$ ca. $430 \mathrm{~nm}$. Furthermore, a second transient, absorbing at $\lambda_{\max }$ ca. $640 \mathrm{~nm}$, is formed; it corresponds to carbazolyl radical $\left(\mathrm{R}_{2} \mathrm{~N}^{\bullet}\right)$ represented in Figure 1.15 $[23]$.

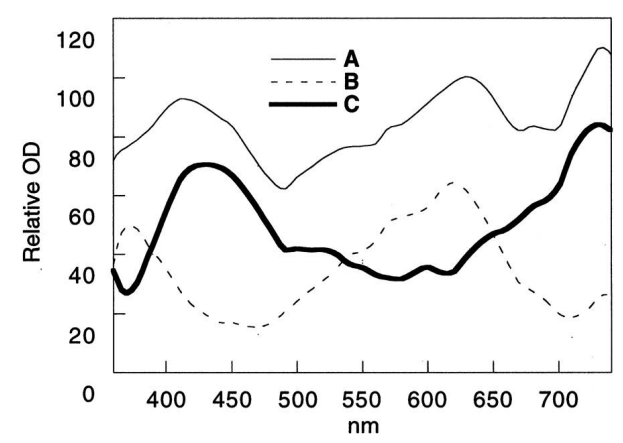

Figure 1.15: Transient absortion spectra of a nitrogen-saturated PBS solution of CRP measured after $150 \mathrm{~ns}(A)$ and $2000 \mathrm{~ns}(B)$. Plot $C$ is the difference (A-B) to observe better CRP triplet and e-(aq). Adapted from reference [23]

Photoreactivity of CRP toward biological targets has been evaluated first through its ability to mediate photoperoxidation of linoleic acid. Upon irradiation, an appreciable amount of dienic hydroperoxides is formed, this amount is higher than that produced by tiaprofenic acid, another NSAID (Figure 1.16). By contrast, 
photoproduct ppCRP does not induce significant photoperoxidation. This can be explained by abstraction of the double allylic hydrogen by CRP aryl radical, which would be the initial step in a Type I radical chain reaction of linoleic acid. The photohemolysis test gives similar results (Figure 1.17), and shows that CRP is able to photosensitize lysis of the erythrocyte membranes, while its photoproduct ppCRP has a slower lytic activity[23].

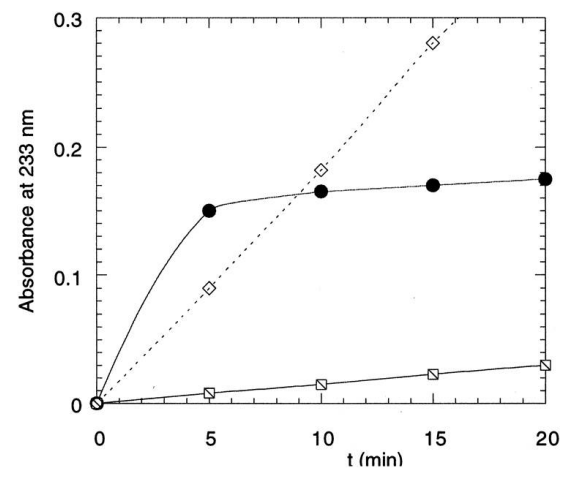

Figure 1.16: Photoperoxidation of linoleic acid sensitized by $\mathbf{C R P}(\bullet), \boldsymbol{p p} \boldsymbol{C R P}(\square)$, and tiaprofenic acid ( $\square$ ). Adapted from reference [23]

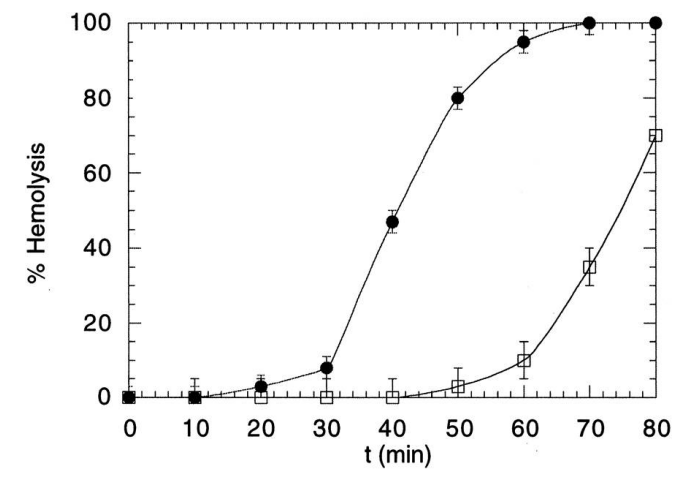

Figure 1.17: Photohemolysis of $R B C$ sensitized by $\mathbf{C R P}(\bullet)$ and ppCRP ( $\square$ ). Adapted from reference [23]

Finally, CRP photodehalogenation can also promote photobinding to the carrier protein human serum albumin (HSA). This photoadduct represents a hapten and can consequently promote a photoallergic reaction. Again, CRP triplet excited state is the key species of this photoreaction as revealed by LFP quenching experiments.

Diclofenac (2-(2,6-dichloroanilino)phenylacetic acid) gives rise to photosensitivity disorders [24]. This has been confirmed by photopatch tests studies [25], as 
well as by the in vivo mouse tail technique[26]. Photodegradation of DCF yields 1-(8-chlorocarbazolyl)acetic acid (ppDCF) as the major photoproduct $[24,27]$ (Figure 1.18).

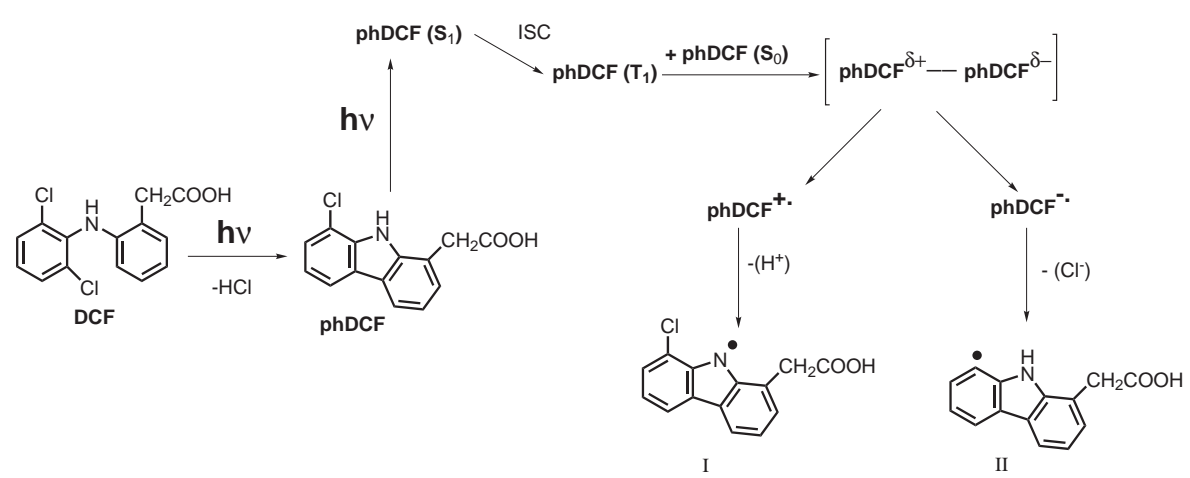

Figure 1.18: Photochemical pathways of diclofenac and its photoproduct. Figure redrawn from reference [28]

For ppDCF, two transient species are observed by LFP (Figure 1.19). The first one corresponds to the triplet excited state signal with an absorption band at $\lambda_{\max }$ ca. $430 \mathrm{~nm}$ and a lifetime of $270 \mathrm{~ns}$, whereas the second transient peaking at $\lambda_{\max }$ ca. $640 \mathrm{~nm}$ was assigned to the corresponding carbazolyl radical $\left(\mathrm{R}_{2} \mathrm{~N}^{\bullet}\right)$ by analogy with other carbazoles (Figure 1.19)[29].

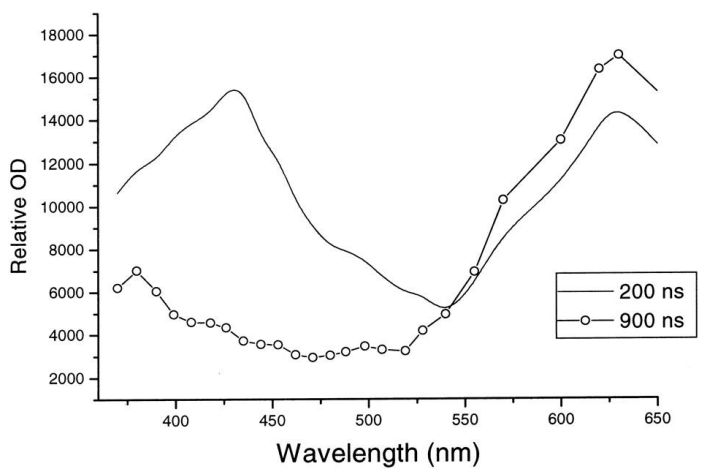

Figure 1.19: Transient absorption spectra of a nitrogen-saturated ethanol solution of ppDCF measured at 200 and 900 ns after the pulse. Adapted from reference [28]

Irradiation of linoleic acid in the presence of ppDCF results in the formation of dienic hydroperoxides (Figure 1.20). This can be explained by abstraction of the double allylic hydrogen by either radical I or II (Type I mechanism). The kinetic pattern observed for this process is in agreement with dehalogenation as the major process involved in lipid peroxidation, as described above for CPF.

Similar conclusions can be made from the photohemolytic study: ppDCF and 


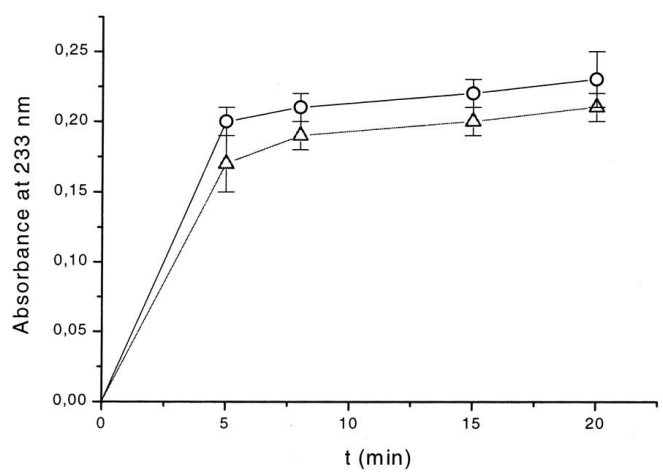

Figure 1.20: Photoperoxidation of linoleic acid sensitized by ppDCF (०) and carprofen $(\triangle)$. Adapted from reference [28]

CRP have a higher lytic activity than DCF (Figure 1.21). Thus, the photosensitization activity of DCF seems to be associated with the photobiological activity of its photoproduct, through the cleavage of its carbon-halogen bond.

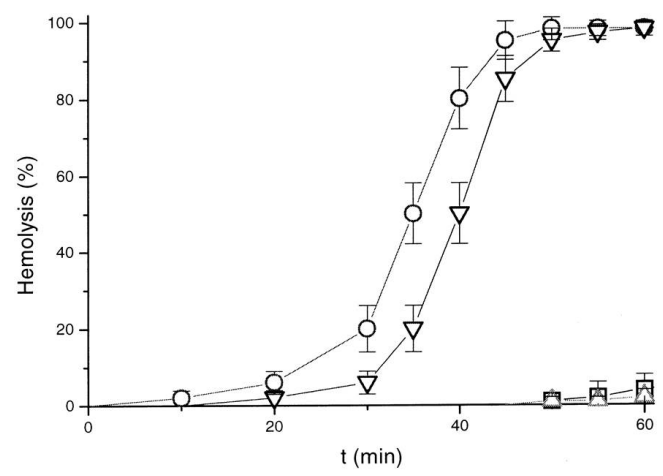

Figure 1.21: Photohemolysis of $R B C$ sensitized by $\mathbf{D C F}(\square)$, ppDCF (०), other photoproduct $(\triangle)$, and carprofen $(\nabla)$. Adapted from reference [28] 


\section{Chapter 2}

\section{Aims}

\subsection{Aims}

In this thesis, the attention will be focused on photosensitization by drugs with the ultimate aim to provide a mechanistically based strategy that allows us to get insights into the molecular mechanism. In this way, study of well-established phototoxic drugs should provide helpful information on the mechanisms. This knowledge could then be applied in the drug development process to design new pharmaceutics with a higher photosafety. Such a strategy will include not only the study of photophysical and photochemical properties of the drug alone but also in the presence of biomolecules like lipids, proteins, DNA, and their simple building blocks.

In this context, we propose the study of three representative photoactive drugs (ie. rosuvastatin, itraconazole and imatinib) to gain information on the different processes related to their photosensitivity side effects.

The following specific goals will be addressed in the present doctoral thesis:

1. To characterize the photophysical properties of the selected drugs. Specifically, to determine their properties in the ground state (absorption), in the singlet excited state (steady state and time resolved fluorescence) and also in the triplet excited state (by means of laser flash photolysis and phosphorescence).

2. To determine and quantify the formation of reactive oxygen species like singlet oxygen during drug irradiation. To assess the limits of the TEMPO/EPR method to achieve this goal.

3. To investigate the photostability of the drug. If photodegradation occurs, to isolate and characterize the photoproducts and to determine their photophysical properties (see aims 1 and 2). 
4. To evaluate the parent drug (or photoproduct) photosensitizing potential through investigation of its interaction with biomolecules or their building blocks.

5. To propose a flow diagram to carry out the study of drugs (or xenobiotics) with potential photosensitizing properties

\subsection{Objetivos}

En esta tesis se centrará la atención en la fotosensibilización promovida por fármacos con el fin último de proporcionar una estrategia que nos permita obtener detalles del mecanismo molecular. De esta manera, el estudio de fármacos conocidos por ser fototóxicos debe proporcionar información útil sobre los mecanismos. Este conocimiento puede ser aplicado en el proceso de desarrollo de moléculas para el diseño de nuevos productos farmacéuticos con un menor riesgo fotoquímico.

Esta estrategia incluirá no sólo el estudio de las propiedades fotofísicas y fotoquímicas de la misma molécula, sino también el estudio de las mismas propiedades en presencia de biomoléculas como lípidos, proteínas, ADN, y sus componentes.

En este contexto, se propone el estudio de tres fármacos fotoactivos representativos (es decir rosuvastatina, itraconazol e imatinib) para obtener información sobre los diferentes procesos relacionados con sus efectos secundarios. Los siguientes objetivos específicos se tratarán en la presente tesis doctoral:

1. Caracterizar las propiedades fotofísicas del fármaco seleccionado. Mas específicamente, determinar sus propiedades en el estado fundamental (absorción), así como en el estado excitado singlete (fluorescencia en el estado estacionario y en tiempo resuelto) y también en el estado excitado triplete (por medio de fotólisis de destello láser y fosforescencia).

2. Detectar y cuantificar la formación de especies reactivas de oxígeno como el oxígeno singlete durante la irradiación de dichas moléculas. Dentro del alcance de este objetivo, también se evaluarán los límites del método EPR/ TEMPO.

3. Evaluar las potenciales interacciones del fármaco original (o fotoproducto) con biomoléculas o sus componentes.

4. Proponer un diagrama de flujo para aclarar los resultados del estudio de dichos fármacos (o xenobióticos) con potenciales propiedades fotosensibilizantes. 


\section{Chapter 3}

\section{Phototoxicity of Rosuvastatin*}

\subsection{Introduction}

In this chapter, the attention has been focused on rosuvastatin (RSV, Figure 3.1), a synthetic statin of third generation also known as "superstatin" for its low $\mathrm{IC}_{50}$ (median inhibitory concentration) value for HMGR inhibition. Photolysis of RSV has previously been studied in the literature; it leads to formation of the stable dihydrophenanthrene-like products (ppRSV and ppRSV3) and to the fully conjugated ppRSV4 compound (Figure 3.1)[30]. Indeed, the photoreaction mechanism has been paralleled with that established for 2-vinylbiphenyl compounds, where photochemical electrocyclization leads to an unstable 8a,9dihydrophenanthrene intermediate, which then undergoes a thermal sigmatropic 1,5-hydrogen shift to yield dihydrophenanthrene (Figure 3.2)[31, 32].

The aim of the present work is to investigate the potential role as photosensitizer of the drug RSV and of one of its photoproducts as photosensitizer, through the study of their photophysical properties and their interaction with key biomolecule building blocks. To achieve this aim, the following points have been addressed:

1. Photophysics of the parent drug rosuvastatin

2. Photophysics of its main photoproduct ppRSV

3. Singlet oxygen generation by ppRSV

4. Interaction of ppRSV with biomolecule building blocks, thymidine (Thd) for DNA and tryptophan (Trp) for proteins.

*Reproduced in part with permission from: Potential Phototoxicity of Rosuvastatin Mediated by Its Dihydrophenanthrene-like Photoproduct; Giacomo Nardi; Virginie Lhiaubet-Vallet; Paula Leandro-Garcia; Miguel A. Miranda Chem. Res. Toxicol., 2011, 24, 1779-1785. Copyright 2011 American Chemical Society. 


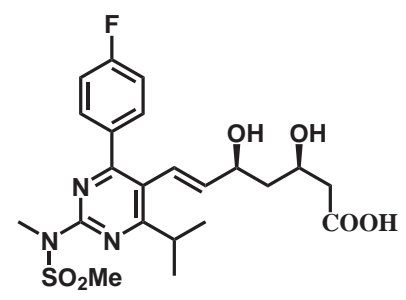

RSV<smiles>CC(C)c1nc(N(C)C)nc2c1CCc1cc(F)ccc1-2</smiles>

ppRSV3

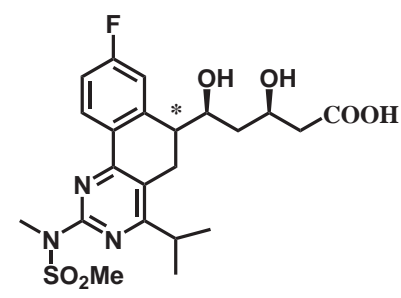

ppRSV<smiles>CC(C)c1nc(N(C)C)nc2c1ccc1cc(F)ccc12</smiles>

ppRSV4

Figure 3.1: Structures of rosuvastatin (RSV) and its photoproducts
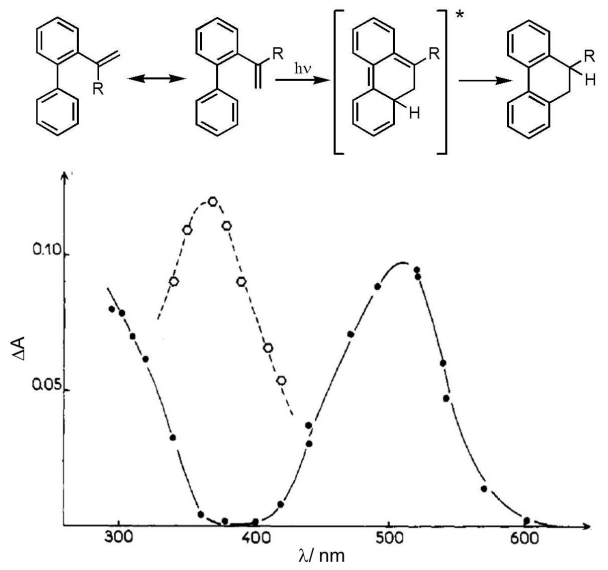

Figure 3.2: Up, general intramolecular photocyclization of 2-vinylbiphenyl-like compound to yield dihydrophenanthrene. Bottom, transient absorption spectra of 1-(o-diphenyl)-1-phenylethylene. Dotted line: triplet absorption. Full line: cyclic intermediate. Figure adapted from ref [31] 


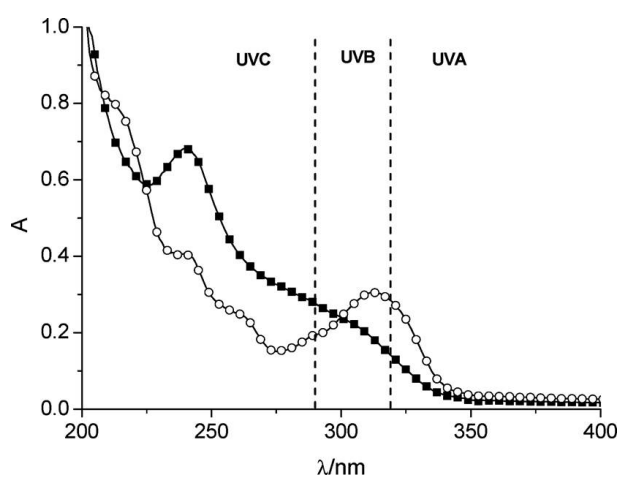

Figure 3.3: Absorption spectra of RSV 4.8 $\times 10^{-5} M(\mathbf{\square})$ and ppRSV $1.5 \times 10^{-5}$ (०) in PBS.

\subsection{Results and discussion}

\subsubsection{Photophysics of rosuvastatin}

Rosuvastatin absorption reaches the UVA region of the spectrum; it exhibits a maximum at $243 \mathrm{~nm}$ and a shoulder until $350 \mathrm{~nm}$ (Figure 3.3). A very weak fluorescence emission was observed at $373 \mathrm{~nm}$ (data not shown). This emission was increasing during measurement of successive spectra with the same sample, suggesting RSV degradation under UV-irradiation.

Photolability was further observed by laser flash photolysis (LFP) experiments performed on $\mathrm{N}_{2}$-degassed PBS solutions of RSV. Indeed, after one laser pulse, the decay monitored at $400 \mathrm{~nm}$ exhibited a remarkable change, suggesting formation of a new intermediate (Figure 3.4). Transient absorption spectrum of RSV, obtained using a fresh sample for each point, showed a long-lived species centered at ca. $550 \mathrm{~nm}$ (Figure 3.5). By comparison with literature data available for 2-vinylbiphenyl derivatives[31, 32] (Figure 3.2) this transient has been assigned to the 8a,9-dihydrophenanthrene intermediate of RSV cyclization leading to the dihydrophenanthrene-like compounds.

Moreover, LFP studies run on a RSV irradiated sample showed a signal with maximum at $400 \mathrm{~nm}$. This species was quenched by oxygen, and thus it was tentatively assigned to the triplet excited state of RSV photoproduct(s). These results agree well with RSV photochemistry corresponding to an electrocyclization process followed by a sigmatropic $\mathrm{H}$ transfer to form the primary photoproduct ppRSV[30]. Moreover, the lack of triplet excited state detection and the low fluorescence emission, indicate that RSV should be considered as an unlikely photosensitizer, as previously reported for ATV [22](for which a photoproduct rather than the parent drug is in the origin of the photosensitized damage to biomolecules). 


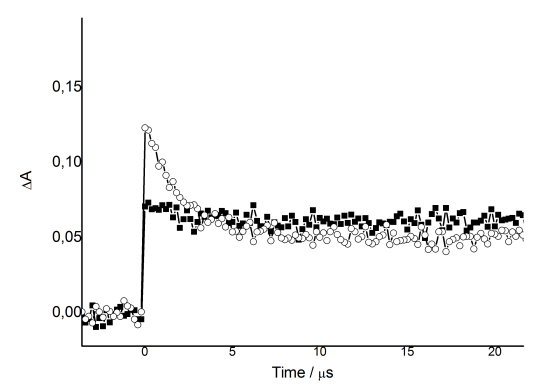

Figure 3.4: $\mathrm{LFP}$ at $308 \mathrm{~nm}$ excitation of $\boldsymbol{R S V}\left(4.8 \times 10^{-5} \mathrm{M}\right)$ in PBS, decays monitored at 400 nm: after the first LFP pulse (ם) and the second LFP pulse (०).

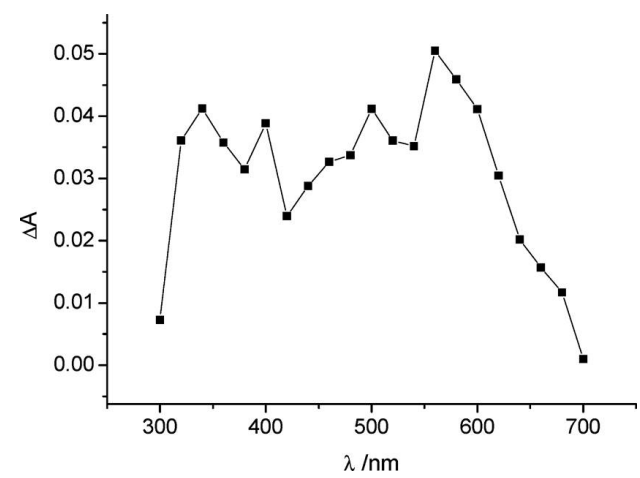

Figure 3.5: Transient absorption spectra of $\mathbf{R S V}\left(4.8 \times 10^{-5} \mathrm{M}\right)$ in PBS solution, recorded using a fresh solution for each laser pulse (Xe/Cl excimer, $308 \mathrm{~nm}$ excitation).

\subsubsection{Photophysics of the major rosuvastatin photoproduct}

As shown in Figure 3.6, ppRSV exhibits a defined absorption band centered at $\lambda_{\max }=313 \mathrm{~nm}$. It is noteworthy that the photoproduct has a stronger absorption in the UVA region than RSV, which thus increases its potential to act as a photosensitizer under solar irradiation. Steady-state fluorescence of ppRSV in ACN solution showed an emission spectrum with $\lambda_{\max }$ at $376 \mathrm{~nm}$ and a fluorescence quantum yield $\Phi_{F}$ of 0.014 , obtained using carprofen as standard $\left(\Phi_{F}=0.068\right)[23]$.

Fluorescence emission was not quenched by oxygen. A singlet-state energy $\left(E_{S}\right)$ of $84 \mathrm{kcal} \mathrm{mol}^{-1}$ was determined by considering the intersection between the normalized emission and excitation spectra (Figure 3.6). Similar results were obtained using PBS and methanol as solvent (Table 3.1). Low temperature emission was also measured in EtOH at $77 \mathrm{~K}$. Under these conditions, ppRSV showed a well-defined emission spectrum with a maximum centered at $460 \mathrm{~nm}$. A triplet excited state energy value $\left(E_{T}(\mathbf{p p R S V})\right)$ of $69.2 \mathrm{kcal} \mathrm{mol}^{-1}$ was obtained from 
the 0 - 0 band of the spectrum.

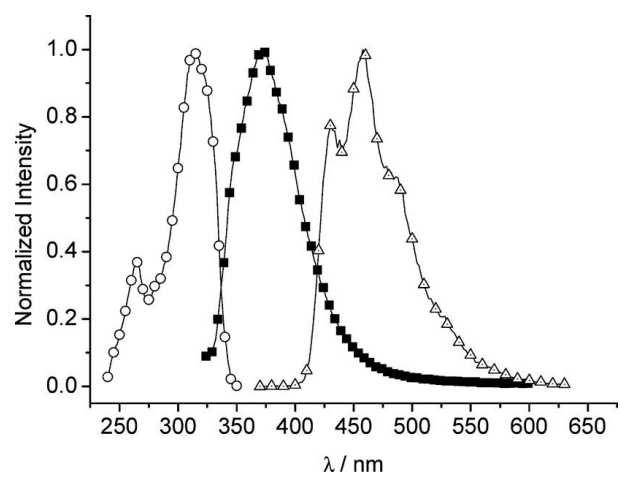

Figure 3.6: Fluorescence excitation $\left(\circ, \lambda_{e m}=376 \mathrm{~nm}\right)$ and emission $\left(\mathbf{\square}, \lambda_{\text {exc }}=314 \mathrm{~nm}\right) \mathrm{of}$ ppRSV in acetonitrile at $295 \mathrm{~K}$. Phosphorescence emission spectrum in EtOH at $77 \mathrm{~K}\left(\triangle, \lambda_{\text {exc }}\right.$ $=312 \mathrm{~nm})$.

Laser flash photolysis of deaerated solutions of ppRSV showed a transient at $400 \mathrm{~nm}$ (Figure 3.7) with lifetime varying from $8 \mu \mathrm{s}$ in methanol to $20 \mu \mathrm{s}$ in PBS. This species was efficiently quenched by oxygen, and thus it was tentatively assigned to ppRSV triplet excited state $\left({ }^{3}\right.$ ppRSV) (Table 3.1$)$. Interestingly, this signal was similar to that observed during LFP of an irradiated sample of $\mathbf{R S V}$ (see Figure 3.5).

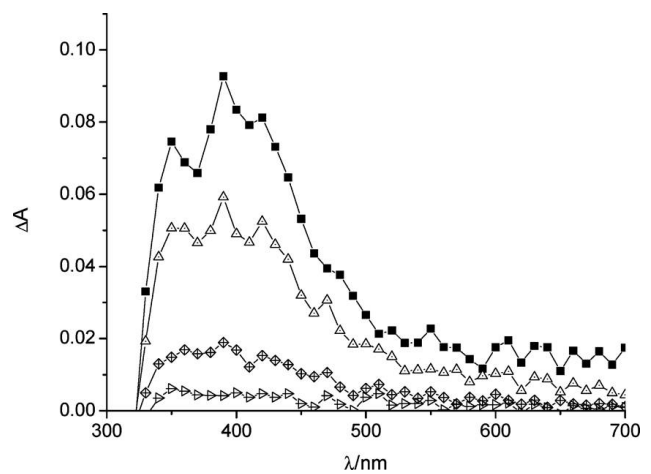

Figure 3.7: Transient spectrum (from 2 to $20 \mu \mathrm{s}$ ) of triplet - triplet transition obtained for a degassed acetonitrile solution of ppRSV $\left(3.3 \times 10^{-5} \mathrm{M}\right)$ after $308 \mathrm{~nm}$ laser excitation.

The nature of ppRSV transient was confirmed by further quenching experiments. In a first stage, a diffusion-controlled process was observed in the presence of $\beta$-carotene $\left(E_{T}\right.$ ca. $\left.20 \mathrm{kcal} \mathrm{mol}^{-1}\right)$. Under these conditions, the transient absorption at $400 \mathrm{~nm}$ disappeared concomitantly with the appearance of a new band peaking at $520 \mathrm{~nm}$, which corresponds to the characteristic T-T absorption of $\beta$ - 


\begin{tabular}{ccccccc} 
Solvent & $\begin{array}{c}\lambda_{\text {em }} \\
(\mathrm{nm})\end{array}$ & $\begin{array}{c}E_{S} \\
\left(\mathrm{kcal} \mathrm{mol}^{-1}\right)\end{array}$ & $\Phi_{F}$ & $\begin{array}{c}\lambda_{T-T} \\
(\mathrm{~nm})\end{array}$ & $\begin{array}{c}\tau_{T} \\
(\mu \mathrm{s})\end{array}$ & $\begin{array}{c}\mathrm{k}_{q}\left(\mathrm{O}_{2}\right) \\
\left(\mathrm{M}^{-1} \mathrm{~s}^{-1}\right)\end{array}$ \\
\hline $\mathrm{PBS}$ & 368 & 84 & 0.036 & 400 & 20 & $1.2 \times 10^{9}$ \\
$\mathrm{MeOH}$ & 370 & 84 & 0.012 & 400 & 10 & $2.6 \times 10^{9}$ \\
$\mathrm{ACN}$ & 376 & 84 & 0.014 & 400 & 8 & $2.0 \times 10^{9}$
\end{tabular}

Table 3.1: Photophysical properties of ppRSV in different solvents

carotene. Thus, a triplet-triplet energy transfer is occurring, which agrees with the triplet state nature of the $400 \mathrm{~nm}$ transient species (Figure 3.8).

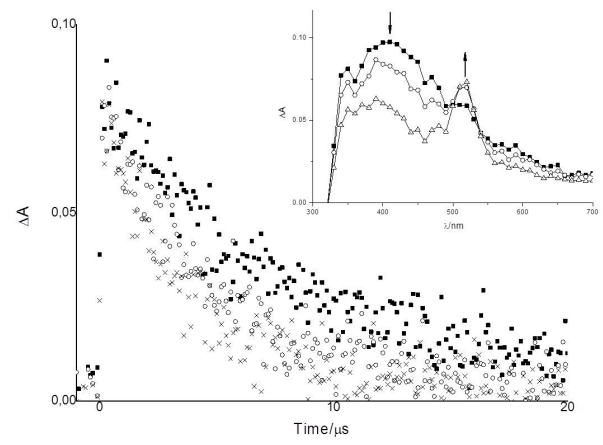

Figure 3.8: LFP at $308 \mathrm{~nm}$ excitation of ppRSV $\left(3.3 \times 10^{-5} \mathrm{M}\right)$ in deaerated ACN, transient decay monitored at $400 \mathrm{~nm}$ without ( $\mathbf{\square})$ and in the presence of increasing concentration of $\beta$-carotene (from 0 to $2.0 \times 10^{-5} \mathrm{M}$ ). Inset: Transient absorption spectrum (from 1 to $5 \mu \mathrm{s}$ ) of triplet-triplet transition obtained for a degassed acetonitrile solution of ppRS $\boldsymbol{V}\left(3.3 \times 10^{-5} \mathrm{M}\right)$ and $\beta$-carotene $\left(2.0 \times 10^{-5} \mathrm{M}\right)$ after $308 \mathrm{~nm}$ laser excitation.

A complementary experiment was also performed; it consisted in the quenching of the triplet excited state of a donor using ppRSV as acceptor. Taking into account the ${ }^{3}$ ppRSV energy value determined above, xanthone was used as a suitable photosensitizer $\left(E_{T}=73.2 \mathrm{kcal} \mathrm{mol}^{-1}\right)$. As shown in Figure 3.9, xanthone triplet-triplet absorption centered at $630 \mathrm{~nm}$ was quenched in the presence of ppRSV with a bimolecular rate constant of $1.6 \times 10^{10} \mathrm{M}^{-1} \mathrm{~s}^{-1}$, thus confirming on the one hand the triplet nature of the $400 \mathrm{~nm}$ transient and on the other hand that $E_{T}\left({ }^{3} \mathbf{p p R S V}\right)$ is lower than $E_{T}$ (xanthone).

Further characterization of ${ }^{3} \mathbf{p p R S V}$ was performed by determining the molar absorption coefficient of its triplet-triplet absorption in acetonitrile. The signals formed after quenching of xanthone triplet excited state by ppRSV or 1methylnaphthalene were compared, using the latter as standard (see experimental section). In this way, a value of $8500 \mathrm{M}^{-1} \mathrm{~cm}^{-1}$ at $400 \mathrm{~nm}$ was obtained, and the intersystem crossing quantum yield $\left(\Phi_{I S C}\right)$ was estimated at 0.8 by means of the comparative method.

As explained in the introduction chapter, singlet oxygen $\left({ }^{1} \mathrm{O}_{2}\right)$ is one of the 


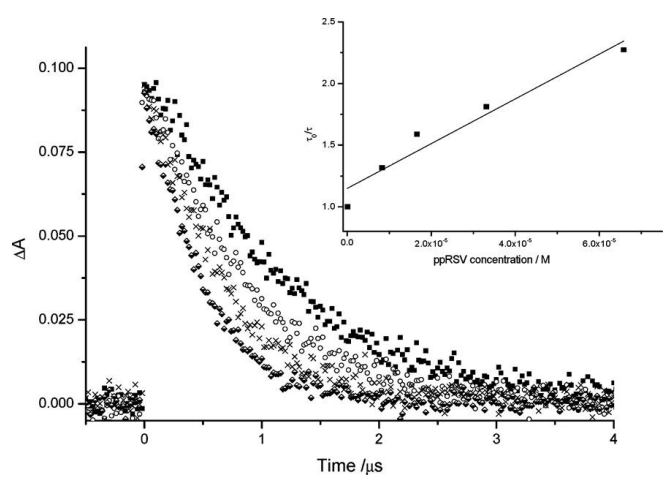

Figure 3.9: LFP at $355 \mathrm{~nm}$ excitation. Decays of xanthone $\left(6.6 \times 10^{-5} \mathrm{M}\right.$ in deaerated acetonitrile) monitored at $630 \mathrm{~nm}$, in the presence of increasing concentration of ppRSV (from 0 to $6.6 \times 10^{-5}$ M). Inset: Stern-Volmer plot.

main reactive oxygen species (ROS) involved in the oxidative damage to living systems. The efficient ${ }^{3}$ ppRSV quenching by molecular oxygen observed by LFP should give rise to the formation of ${ }^{1} \mathrm{O}_{2}$ by a triplet-triplet energy transfer process (eq. 5, Figure 1.16). To confirm production of this species, spin trapping experiments were conducted using the well-known conversion of TEMP to the stable free radical TEMPO, detectable by EPR analysis (for more details see chapter 6). A methanolic solution of TEMP was irradiated in the presence of ppRSV. As shown in Figure 3.10, under these conditions, detection and increase of the typical TEMPO signal as a function of irradiation time provided a clear evidence for the role of ppRSV as singlet oxygen sensitizer.

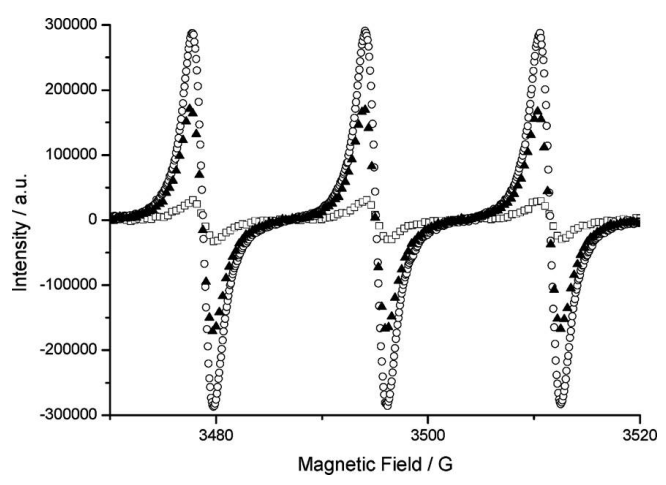

Figure 3.10: TEMPO signals obtained by irradiation of a methanolic solution of TEMP (10 mM) and ppRSV $\left(3.3 \times 10^{-5} \mathrm{M}\right)$ : without irradiation $(\square)$ and after $5(\mathbf{\Delta})$ and 7 (०) min of irradiation

The quantum yield of ${ }^{1} \mathrm{O}_{2}$ formation was determined by time-resolved near-IR emission studies using naproxen as standard $\left(\Phi_{\Delta}=0.27\right.$ in acetonitrile[33]). The intensity of the characteristic singlet oxygen emission at $1270 \mathrm{~nm}$ was plotted as a function of the laser intensity for oxygenated acetonitrile solutions of ppRSV and naproxen. A quantum yield of 0.3 was obtained from the ratio of the linear plot 
slopes. The same value was obtained by registering steady state emission of ${ }^{1} \mathrm{O}_{2}$, using perinaphthenone as standard $\left(\Phi_{\Delta}=1\right.$ in acetonitrile [34])

All the photophysical properties of ppRSV could be summarized in the Figure 3.11. After promotion to its singlet excited state (eq. 1, Figure 1.16), ppRSV can undergo different deactivation pathways, including fluorescence (eq. 2) and intersystem crossing (eq. 3). Based on LFP experiments, an efficient triplet excited state formation $\left(\Phi_{I S C}=0.8\right)$ has been established. Moreover, a high triplet state energy $\left(E_{T}=69.2 \mathrm{kcal} \mathrm{mol}^{-1}\right)$ has been determined by phosphorescence emission studies (eq. 4). Indeed, triplet excited states have been demonstrated to be crucial species in photosensitizing reactions $[23,33]$. Thus, in connection with ppRSV photophysical properties, three processes have been considered to investigate the interaction between ${ }^{3}$ ppRSV and biomolecules (eq. 6-8, Figure 3.11).

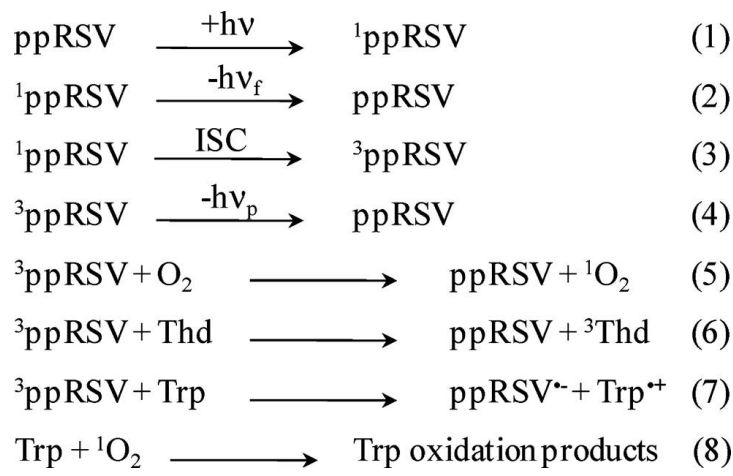

Figure 3.11: Summary of all reactions involved in rosuvastatin phototoxicity promoted by its photoproduct.

\subsubsection{Interaction of ppRSV with biomolecules}

\section{Thymidine}

In a first stage, interaction with DNA components was considered by monitoring the ${ }^{3}$ ppRSV decay at $400 \mathrm{~nm}$ in the presence of increasing amounts of Thd. As shown in Figure 3.12, addition of the nucleoside results in the shortening of ${ }^{3}$ ppRSV lifetime. A bimolecular quenching rate constant of $3.0 \times 10^{7} \mathrm{M}^{-1} \mathrm{~S}^{-1}$ was determined from the Stern-Volmer plot (Figure 3.12, inset).

The involved mechanism that corresponds to a triplet-triplet energy transfer from ppRSV to thymidine (Thd, equation 6 of Figure 3.11) could give rise to thymidine cyclobutane dimers (Thd $<>$ Thd), an important DNA lesion[35] (Figure 3.13). Mechanism of photosensitization could be outlined as follows: after absorption of light, the photosensitizer reaches its singlet excited state and is subsequently promoted to its triplet excited state. Then, the triplet excited state of Thd is populated through a triplet-triplet energy transfer process. This state can react with 


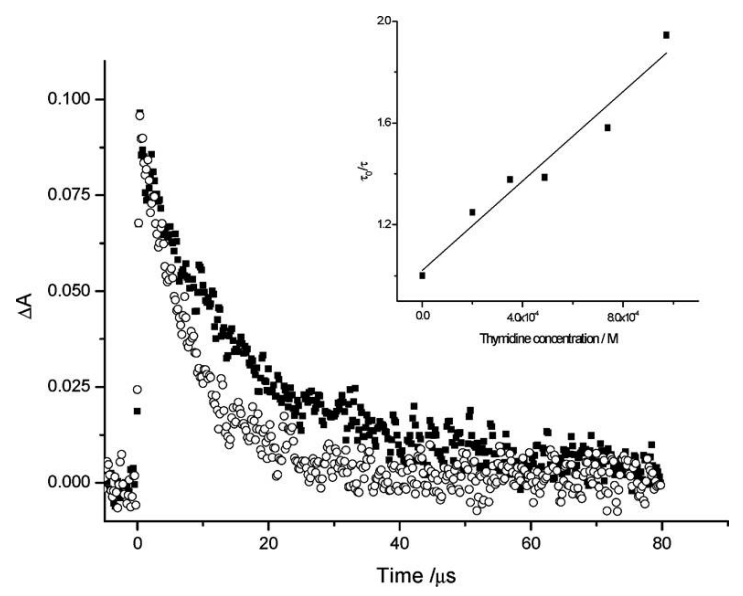

Figure 3.12: $\mathrm{LFP}$ at $308 \mathrm{~nm}$ excitation of ppRSV $\left(3.3 \times 10^{-5} \mathrm{M}\right)$ in deaerated PBS, transient decay monitored at $400 \mathrm{~nm}$ without (口) and with $10^{-3} \mathrm{M}$ Thd (o). Inset: Stern - Volmer plot.

another molecule of Thd in its ground state $\left({ }^{0} \mathrm{Thd}\right)$ to form a cyclobutane thymidine dimer. As a requirement for this process to occur, the triplet state energy of the photosensitizer has to be higher than that of the DNA base. Few compounds are known to exhibit the appropriate properties to act as efficient sensitizers. In this context, the $E_{T}$ value of ${ }^{3} \mathbf{p p R S V}$, determined as $67 \mathrm{kcal} \mathrm{mol}^{-1}$, is high enough to make this compound a potential Thd $<>$ Thd photosensitizer, in fact ${ }^{3}$ ppRSV triplet excited state lies close to that of benzophenone or carprofen, both reported as Thd $<>$ Thd photosensitizers. Indeed, the obtained value is in agreement with expectations from the triplet energy gap between donor and acceptor[35].

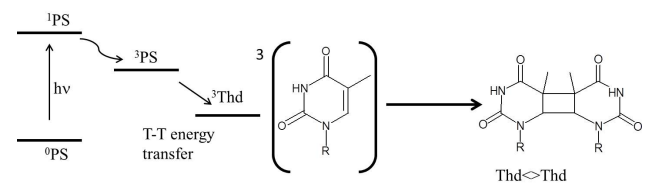

Figure 3.13: Schematic representation of photosensitized formation of thymidine dimer.

\section{Tryptophan}

Related studies were also performed with a protein building block. Specifically Trp represents an interesting probe as it can be oxidized both by Type I and Type II mechanisms. In this context, the oxidizing potential of ${ }^{3}$ ppRSV has been evaluated by means of time-resolved and steady-state experiments. Direct interaction of ${ }^{3}$ ppRSV with Trp has been studied by LFP. Quenching by this amino acid (Figure 3.14) was found to occur with a bimolecular rate constant of $5.0 \times 10^{7} \mathrm{M}^{-1} \mathrm{~s}^{-1}$, leading to formation of the long-lived tryptophanyl radical $\left(\lambda_{\max }\right.$ at 310 and 520 
$\mathrm{nm})[36]$. This is in agreement with a mechanism involving electron transfer from Trp to ${ }^{3} \mathbf{p p R S V}$, followed by deprotonation of the resulting radical cation at $\mathrm{pH}$ $=7.4$, to form the tryptophanyl radical [36].

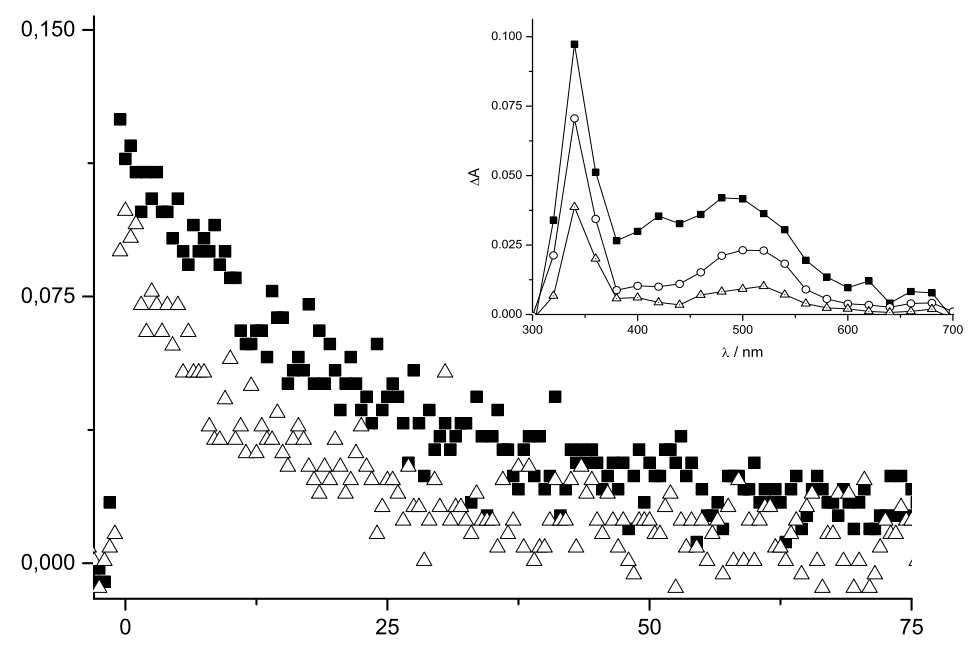

Figure 3.14: LFP at $308 \mathrm{~nm}$ excitation of ppRSV $\left(3.3 \times 10^{-5} \mathrm{M}\right)$ in deaerated PBS, transient decay monitored at $400 \mathrm{~nm}$ without $(\mathbf{\square})$ and with $5 \times 10^{-6} \mathrm{M}(\triangle)$ Trp. Inset: Transient absorption spectrum of ppRSV in the presence of $1.8 \times 10^{-5} M$ Trp registered 2, 10, $60 \mu \mathrm{s}$ after the laser pulse.

In addition, the ppRSV photoreactivity was investigated by steady-state photolysis of ppRSV at $320 \mathrm{~nm}$ in the presence of equimolar amounts of Trp. The disappearance of the amino acid fluorescence emission $\left(\lambda_{\max }=353 \mathrm{~nm}\right)$ with irradiation time was observed and taken as measurement of the extent of oxidation (Figure 3.15). To check the involvement of a type II mechanism, a parallel experiment was performed in $\mathrm{D}_{2} \mathrm{O}$, where the lifetime of ${ }^{1} \mathrm{O}_{2}$ is longer than in water. As a matter of fact, a significant enhancement of the reaction rate was observed under these conditions, in agreement with Trp oxidation by ${ }^{1} \mathrm{O}_{2}$.

This result is in accordance with the ppRSV singlet oxygen quantum yield $\Phi_{\Delta}$ of 0.3 (eq. 5, Figure 3.11). In addition, a Type I reactivity has also been evidenced by LFP. Indeed, ${ }^{3}$ ppRSV quenching by Trp (eq. 7, Figure 3.11) leads to formation of the tryptophanyl radical arising from an electron transfer process. Therefore, oxygen and Trp compete for ${ }^{3}$ ppRSV quenching. The predominance of Type I or Type II mechanism can be inferred from the absolute quenching rates $\left(k_{q} \times[\mathrm{Q}]\right)$ that not only consider the bimolecular rate constant $k_{q}$ but also the concentration of the quencher [Q]. Thus, considering the maximum quencher concentration used in this work (i.e. $1.3 \times 10^{-3} \mathrm{M}$ and $20 \times 10^{-6} \mathrm{M}$ for oxygen and Trp, respectively), 

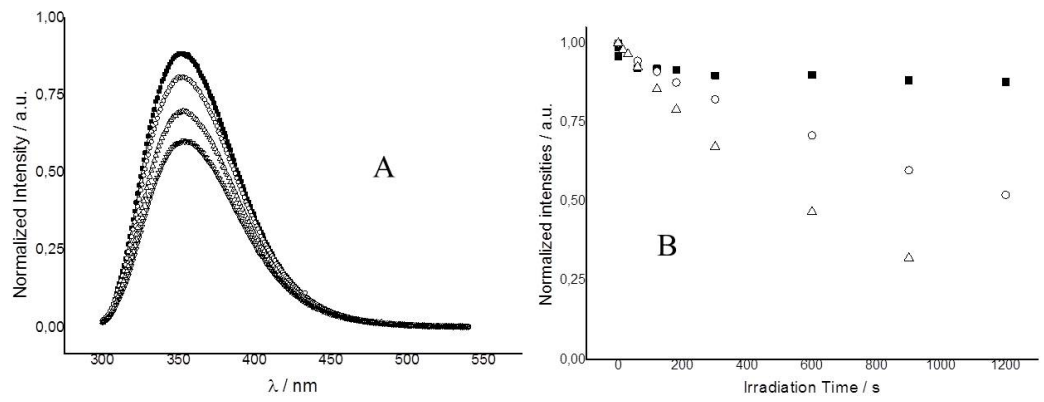

Figure 3.15: (A) $1.8 \times 10^{-5} \mathrm{M}$ Tryptophan fluorescence emission $\left(\lambda_{\text {exc }}=282 \mathrm{~nm}\right.$ ) with an equimolar concentration of ppRS $\boldsymbol{V}$, recorded at increasing irradiation time. (B) Tryptophan photodegradation. Normalized emission at $\lambda_{e m}=353 \mathrm{~nm}$ monitored as a function of irradiation time: Trp alone in PBS (ם), and Trp in the presence of equimolar amounts of ppRSV $\left(2 \times 10^{-5} \mathrm{M}\right)$ in PBS (०) and in deuterium oxide as solvent $(\triangle)$.

a Type II / Type I ratio of 14 is obtained. Although this value only reflects the competition between processes (5) and (7) of Figure 3.11 and does not take into account the subsequent steps, it clearly indicates that Trp is mainly decomposed by a singlet oxygen process.

\subsection{Conclusion}

It has been demonstrated that rosuvastatin, a photolabile UV-absorbing statin, presents the appropriate properties of an efficient photosensitizer, acting through photoproduct formation. The attention has been placed on RSV main photoproduct (ppRSV). Indeed, the photobehavior of this dihydrophenanthrene-like compound presents the essential components needed for an efficient biomolecule photosensitizer i.e. (i) a high intersystem crossing quantum yield $\left(\Phi_{I S C}=0.8\right)$, (ii) a triplet excited state energy of ca. $67 \mathrm{kcal} \mathrm{mol}^{-1}$, and (iii) a quantum yield of singlet oxygen formation of 0.3. Furthermore, laser flash photolysis studies reveal a triplet - triplet energy transfer from the triplet excited state of $\mathbf{p p R S V}$ to thymidine, leading to the formation of cyclobutane thymidine dimers, an important type of DNA lesion. Finally, tryptophan has been used as a probe to investigate the Type I and / or Type II character of ppRSV - mediated oxidation. On the basis of the obtained results, rosuvastatin, through its major photoproduct ppRSV, should be considered as a potential sensitizer and might be in the origin of undesired side effects like phototoxicity and/ or photogenotoxicity. 


\subsection{Experimental part}

In this section the specific experimental procedure for this chapter is described. General experimental procedures, like UV-Vis absorption spectra or emissions, are described in detail at the general experimental chapter 7 .

\subsubsection{Chemicals}

Rosuvastatin was purchased from KEMPROTEC Limited and was used without further treatment. 2,2,6,6-Tetramethylpiperidine (TEMP) and $\beta$-carotene were purchased from Fluka. Deuterated water $\left(\mathrm{D}_{2} \mathrm{O}\right)$, xanthone, carprofen (CRP), naphthalene (NP), naproxen, perinaphthenone, L-tryptophan (Trp), thymidine (Thd), 1-methylnaphthalene (MeNP) and benzophenone (BP) were from Sigma Aldrich. The reagent grade solvents were obtained from Scharlau and used without further purification. Phosphate buffered saline (PBS) solutions of $0.01 \mathrm{M}(\mathrm{pH}$ $=7.4$ ) were prepared by dissolving tablets (Sigma-Aldrich) in Milli-Q water.

\subsubsection{Photochemical synthesis of ppRSV}

Compound ppRSV was isolated as previously described in the literature [30]. Briefly, a dispersion of rosuvastatin calcium $(75 \mathrm{mg}$ in $150 \mathrm{~mL}$ of water) was irradiated for 20 min in Pyrex tubes using the photoreactor equipped with six lamps. The irradiation mixture was dried under vacuum and separated by silica gel TLCchromatography eluting with $\mathrm{CH}_{2} \mathrm{Cl}_{2} / \mathrm{MeOH}$ (95:5) with drops of acetic acid (two runs) to obtain the diastereometric mixture of ppRSV. All of the experiments were conducted at room temperature and under air atmosphere. The ${ }^{1} \mathrm{H}$ and ${ }^{13} \mathrm{C}$ NMR spectral data were identical to those previously reported[30]. Although the two diastereoisomers obtained can be chromatographically separated, the photophysical and photobiological experiments were performed with the diastereoisomeric mixture.

\subsubsection{LFP experiments}

Photosensitization of ppRSV triplet excited state by xanthone was performed using $355 \mathrm{~nm}$ excitation wavelength, whereas determination of ppRSV triplet excited state properties (lifetime, intersystem crossing quantum yield, interaction with biological compounds etc...) was done exciting at $308 \mathrm{~nm}$. In the case of rosuvastatin LFP was also performed with $308 \mathrm{~nm}$ laser.

A modified energy transfer methodology was used to determine the molar absorption coefficient of triplet-triplet transition of ppRSV $\left(\epsilon\left({ }^{3} p p R S V_{400}\right)\right)$. It consists in the quenching of xanthone triplet excited state $(\lambda=633 \mathrm{~nm})$ by ppRSV or 1-methylnaphthalene, used as standard. Molar absorption coefficient of ${ }^{3} \mathbf{p p R S V}$ was obtained from the ratio of $\Delta A$ of $\mathbf{p p R S V}$ (at $\lambda=400 \mathrm{~nm}$ ) and 1-methylnaphthalene (at $\lambda=415 \mathrm{~nm}$ ) when more than $95 \%$ of xanthone triplet was quenched. The following equation was used: 


$$
\epsilon\left({ }^{3} p p R S V_{400}\right)=\epsilon\left({ }^{3} M e N P_{415}\right) \times \frac{\Delta A\left({ }^{3} p p R S V_{400}\right)}{\Delta A\left({ }^{3} M e N P_{415}\right)}
$$

where $\Delta A\left({ }^{3} p p R S V_{400}\right)$ and $\Delta A\left({ }^{3} M e N P_{415}\right)$ refer to the transient absorption of ppRSV and 1-methylnaphthalene triplet state (at 400 and $415 \mathrm{~nm}$, respectively) at the end of the process, and $\epsilon\left({ }^{3} M e N P_{415}\right)$ corresponds to the known molar absorption coefficient of the 1-methylnaphthalene triplet at $415 \mathrm{~nm}(\epsilon=$ $11200 \mathrm{M}^{-1} \mathrm{~cm}^{-1}$ in acetonitrile[37]).

Then, intersystem crossing quantum yield $\left(\Phi_{I S C}\right)$ was determined by the comparative method taking into account the amount of ${ }^{3}$ ppRSV and naphthalene populated after $308 \mathrm{~nm}$ laser excitation. Isoabsortive degassed acetonitrile solutions of both compounds were used. So, $\left(\Phi_{I S C}\right)$ was obtained by using the following equation:

$$
\Phi_{I S C}\left({ }^{3} p p R S V\right)=\Phi_{I S C}\left({ }^{3} N P\right) \times \frac{\Delta A\left({ }^{3} p p R S V_{400}\right)}{\Delta A\left({ }^{3} N P_{420}\right)} \times \frac{\epsilon\left({ }^{3} N P_{420}\right)}{\epsilon\left({ }^{3} p p R S V_{400}\right)}
$$

where $\Phi_{I S C}\left({ }^{3} N P\right)$ corresponds to the intersystem crossing quantum yield of naphthalene; $\epsilon\left({ }^{3} N P_{420}\right)$ refers to the molar absorption coefficient of naphthalene triplet at $420 \mathrm{~nm}$;

$\Delta A\left({ }^{3} p p R S V_{400}\right)$ and $\Delta A\left({ }^{3} N P_{420}\right)$ refer to the transient absorption of ${ }^{3} \mathbf{p p R S V}$ and NP triplet at 400 and $420 \mathrm{~nm}$, respectively. The values of $\epsilon\left({ }^{3} N P_{420}\right)$ and $\Phi_{I S C}\left({ }^{3} \mathrm{NP}\right)$ in acetonitrile were taken as $15000 \mathrm{M}^{-1} \mathrm{~cm}^{-1}$ and 0.8 , respectively[38].

\subsubsection{Singlet oxygen measurements}

All measurements were made at room temperature, under air atmosphere, using acetonitrile as solvent in $1 \mathrm{~cm}$ pathway quartz cuvettes. The absorbance of the samples was 0.30 at the laser wavelength. The singlet oxygen quantum yield $\left(\phi_{\Delta}\right)$ was determined using naproxen in acetonitrile $\left(\phi_{\Delta}=0.27\right)$ as standard [33]. Singlet oxygen formation was calculated from the slope of the plots of signal intensity at zero time versus laser light intensity according to the following equation:

$$
\phi_{\Delta(\text { sample })}=\frac{I_{\text {sample }}}{I_{\text {standard }}} \times \phi_{\Delta(\text { standard })}
$$

where $I_{\text {sample }}$ is the emission intensity for the sample,

$I_{\text {standard }}$ is the emission intensity for the standard and $\phi_{\Delta(\text { standard })}$ is the standard quantum yield of singlet oxygen formation.

\subsubsection{EPR trapping experiments}

Analysis was performed with the EPR spectrometer described in chapter 7 recording the EPR signal of the free radical TEMPO generated by reaction of singlet oxygen with TEMP [39]. Aerated methanolic solutions of $10 \mathrm{mM}$ TEMP containing ppRSV, with an absorbance of 0.3 at $300 \mathrm{~nm}$, were irradiated in a 
multilamp photoreactor equipped with $300 \mathrm{~nm}$ centered lamps; the EPR spectra were recorded at different irradiation times.

\subsubsection{Tryptophan photodegradation}

PBS solution of ppRSV $\left(2 \times 10^{-5} \mathrm{M}\right)$ containing an equimolar concentration of tryptophan were irradiated at $320 \mathrm{~nm}$ using a MicroBeam system (see chapter 7. Tryptophan fluorescence emission intensity $\left(\lambda_{e x}=282 \mathrm{~nm}, \lambda_{e m}=353 \mathrm{~nm}\right)$ was recorded at increasing irradiation time. A parallel experiment was performed under identical conditions using deuterium oxide as the solvent. A solution of tryptophan in PBS $\left(2 \times 10^{-5} \mathrm{M}\right)$ was used as control. 


\section{Chapter 4}

\section{Phototoxicity of Itraconazole*}

\subsection{Introduction}

\subsubsection{Itraconazole and its photoadverse effects}

Itraconazole (1, Figure 4.1) belongs to the azole family of antifungal agents. This relatively safe and orally bioavailable drug is a broad-spectrum triazole derivative, which generally shows a lower toxicity than the imidazole antifungals. As a matter of fact, it represents an important therapeutic option in the treatment against dermatophytes, dimorphic fungi in the skin, some molds and also against dermatomycosis of glabrous skin. The pharmacological activity of $\mathbf{1}$ relies on its ability to inhibit specifically the fungi cytochrome P450 14- $\alpha$-sterol demethylase, responsible for demethylation of lanosterol, blocking this way the synthesis of ergosterol, an essential component of the fungi membrane (Figure 4.2). Ergosterol synthesis inhibitors suppress fungal cell growth under most circumstances (fungistatic effect), and they can sometimes cause fungal cell death (fungicidal effect). Recently, $\mathbf{1}$ has also demonstrated a selective inhibitory activity against multiple aspects of angiogenesis associated with non small cell lung cancers[40, 41].

Among the adverse effects of antifungal triazole drugs, some medical cases of photosensitivity as skin responses upon exposure to sunlight have been reported to occur on skin exposed areas; they correspond to: erythema, oedema and vesicles on sun-exposed areas, but also visual disturbances (as photophobia or blurred vision).[42-45]

\footnotetext{
* Generation of reactive aryl radical intermediates in the reductive photodehalogenation of itraconazole ; Giacomo Nardi; M. Luisa Marin; Pierre A. de Souza; Virginie LhiaubetVallet; Miguel A. Miranda; RSC Adv., 2014, 4, 2687-2693 (http://pubs.rsc.org/en/content/ articlelanding/2014/ra/c3ra43644f) - Reproduced by permission of The Royal Society of Chemistry (RSC)
} 


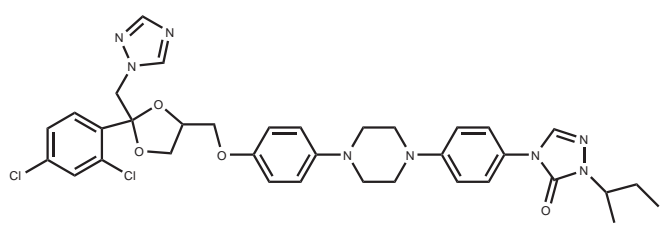

1

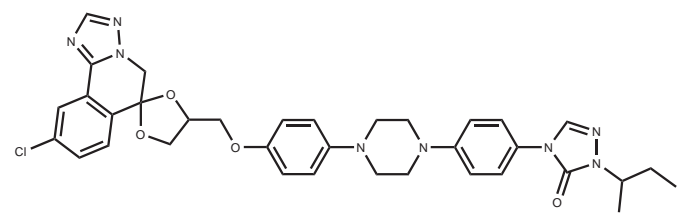

2

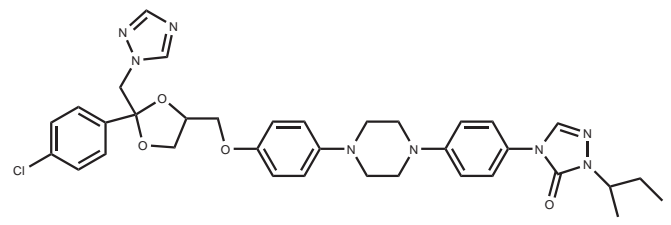

3

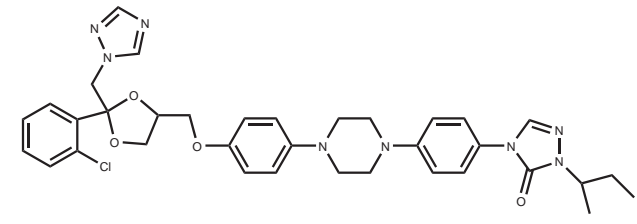

4

Figure 4.1: Structure of itraconazole (1) and its photoproducts 2-4.
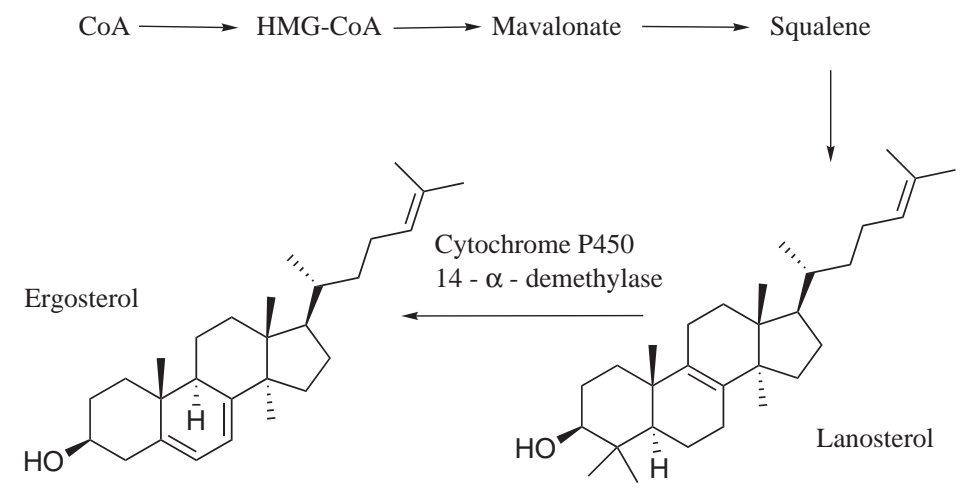

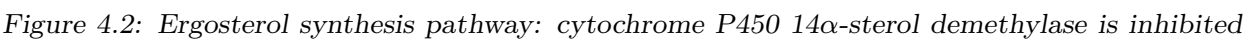
by 1 
However, in spite of their wide use as antifungal agents, the photobehavior of these azole drugs has been scarcely investigated[46-49].

In this context, itraconazole has been selected here to investigate whether free radicals arising from a photodehalogenation process may be responsible for the observed in vivo photosensitivity responses[50]. As a matter of fact, the 2,4-dichlorophenyl moiety of $\mathbf{1}$ presents some photochemical similarities with the photolabile nonsteroidal antiinflammatory drugs carprofen or diclofenac (see introduction chapter). Both suffer a photodechlorination that leads to undesired photobiological effects, as revealed by the photohemolysis of red blood cells and photodynamic lipid peroxidation $[23,28,50]$.

In the present chapter, the photophysical and photochemical studies of this drug have been addressed; this includes steady state photolysis, fluorescence and phosphorescence spectroscopies, as well as photoreactivity in the presence of biological models.

\subsection{Results and discussion}

\subsubsection{Photophysical properties of itraconazole}

The absorption spectrum of $\mathbf{1}$ was recorded in different solvents in order to evaluate its capability to absorb in the different regions of the UV spectrum. As shown in Figure 4.3, 1 exhibits a main band with maximum at ca. $260 \mathrm{~nm}$ and a tail reaching the UVB region. The position of the maximum was weakly dependent on the solvent; it was shifted from $262 \mathrm{~nm}$ in methanol to 266 in dichloromethane (Figure 4.3 and Table 4.1).

After confirming the itraconazole absorption properties as possible photosensitizer, its excited states were investigated. Steady-state fluorescence of 1 showed a very weak emission centered at $\lambda_{\max }=376 \mathrm{~nm}$ in methanol (Figure 4.4). It corresponds to a singlet excited state energy $\left(E_{S}\right)$ of $85 \mathrm{kcal} \mathrm{mol}^{-1}$, which was determined by considering the intersection between the normalized emission and excitation spectra $\left(\lambda_{0-0}\right)$. Similar results were obtained using $\mathrm{CH}_{2} \mathrm{Cl}_{2}$ or acetonitrile as solvents (Table 4.1). The fluorescence quantum yields $\left(\Phi_{F}\right)$ reported in Table 4.1 were determined using carprofen as standard $\left(\Phi_{F}=0.068\right.$ in acetonitrile). The obtained values of ca. 0.01 showed that emission is not the preferred deactivation pathway of the singlet excited state. Thus, crossing to the triplet excited state has been studied next as a potential deactivation pathway.

In this context, low temperature phosphorescence emission was also performed in ethanol at $77 \mathrm{~K}$. Under these conditions, the phosphorescence spectrum of 1 showed a band with maximum at $421 \mathrm{~nm}$ (Figure 4.4). Thus, a triplet excited state energy value of $c a .75 \mathrm{kcal} \mathrm{mol}^{-1}$ was obtained. Laser flash photolysis of 1 was also run to gain information on its triplet excited state at room temperature; 


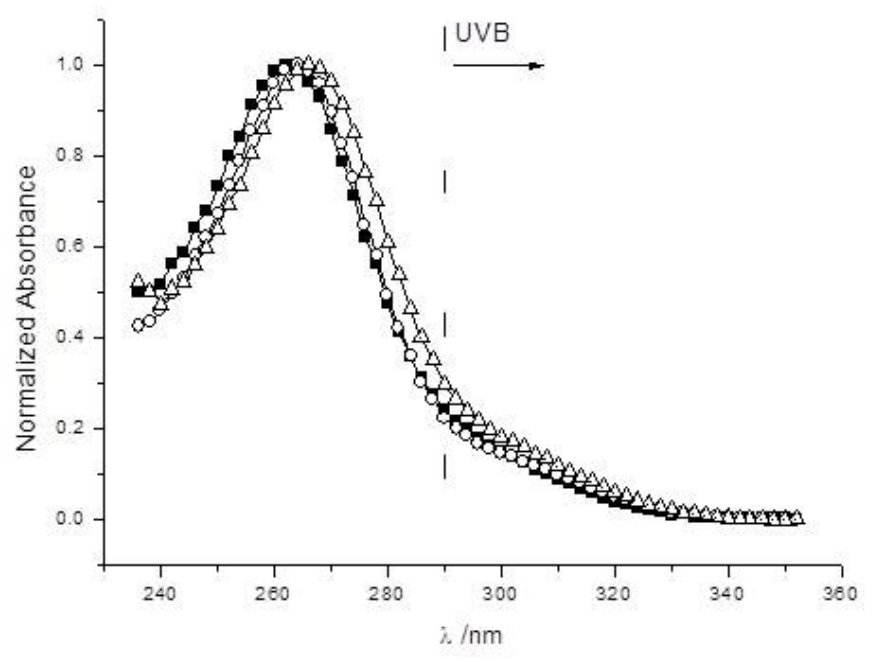

Figure 4.3: Absorption spectra of 1 in different solvents: $\mathrm{MeOH}$ (solid squares), acetonitrile (circles) and dichloromethane (triangles).

\begin{tabular}{cccccc} 
Solvent & $\begin{array}{c}\lambda_{\max } \\
(\mathrm{nm})\end{array}$ & $\begin{array}{c}\varepsilon \\
\left(\mathrm{M}^{-1} \mathrm{~cm}^{-1}\right)\end{array}$ & $\begin{array}{c}\lambda_{\text {em }} \\
(\mathrm{nm})\end{array}$ & $\begin{array}{c}E_{S} \\
\left(\mathrm{kcal} \mathrm{mol}^{-1}\right)\end{array}$ & $\Phi_{F}$ \\
\hline $\mathrm{CH}_{2} \mathrm{Cl}_{2}$ & 266 & 37000 & 370 & 89 & 0.010 \\
$\mathrm{MeOH}$ & 262 & 35500 & 376 & 85 & 0.013 \\
$\mathrm{ACN}$ & 264 & 36000 & 379 & 85 & 0.012
\end{tabular}

Table 4.1: Photophysical properties of 1 in different solvents

however, no transient species were observed. The absence of detectable triplet excited states suggests that the deactivation pathway could be related to the photoreactivity of the molecule.

\subsubsection{Photochemistry of itraconazole}

\section{Photoproducts}

After investigating the photophysical behavior of $\mathbf{1}$, its photostability was addressed. For this purpose, aerated acetonitrile solutions of the drug were UVB irradiated, and the course of the reaction was followed by HPLC. In spite of its moderate absorption above $290 \mathrm{~nm}, 1$ suffered a significant photodegradation, as observed in the typical HPLC chromatogram shown in Figure 4.5. Three photoproducts were mainly formed. These compounds were isolated by preparative HPLC, and characterized by NMR and HRMS (see appendix A). Their mass spectrometric analysis revealed the typical isotopic pattern of monochlorinated com- 


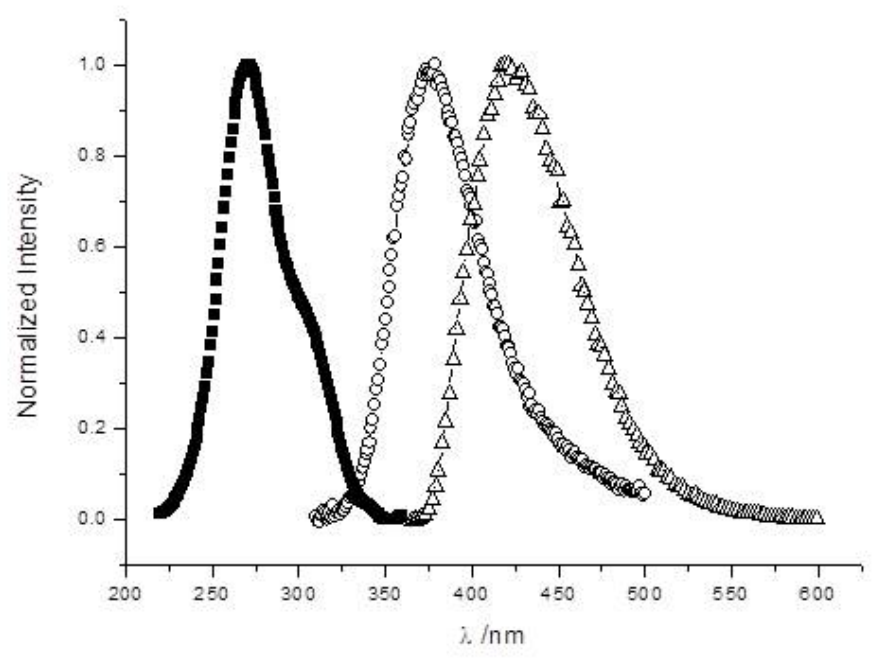

Figure 4.4: Normalized excitation spectra of 1 in $\mathrm{MeOH}$ (solid squares, $\lambda_{\text {em }}=376 \mathrm{~nm}$ ), fluorescence emission (circles, $\lambda_{e x c}=262 \mathrm{~nm}$ ). Phosphorescence emission spectrum in EtOH at $77 \mathrm{~K}$ (triangles, $\left.\lambda_{\text {exc }}=262 \mathrm{~nm}\right)$.

pounds. The structure of $\mathbf{2}$ was assigned on the basis of the molecular ion obtained at $m / z 669.2704$, which corresponds to the loss of $\mathrm{HCl}$ from the parent drug, together with the ${ }^{1} \mathrm{H}$ and ${ }^{13} \mathrm{C}$ NMR spectra, which are in agreement with formation of a new six membered ring (Figure 4.6). The other two main photoproducts were also found to result from a dehalogenation process. They were assigned to $\mathbf{3}$ and $\mathbf{4}$ (Figure 4.1), which correspond to reductive dechlorination in ortho (Figure 4.7) and para position (Figure 4.8), respectively (both with $m / z 671.2861$ ). In these last two cases, the change of the hyperfine structure of the aromatic part of the spectrum, due the replacement of $\mathrm{Cl}$ with $\mathrm{H}$, is quite clear. In fact, in compound $\mathbf{3}$ there is a more symmetric distribution of signals at 7.40-7.20 due to the $\mathrm{Cl}$ substitution in para position. While in compound 4 , doublets change to doublet of doublets due to the presence of a second small coupling constant in the aromatic ring . Interestingly, cyclized compound $\mathbf{2}$ prevailed over the ortho- and para-dechlorinated products $\mathbf{3}$ and $\mathbf{4}$, which were obtained in smaller amounts (Figure 4.9).

\section{Mechanistic hypothesis}

Thus, 1 was found to be photolabile, and its exposure to UVB light resulted in consumption of the drug by a photodechlorination process leading to three photoproducts (Figure 4.1). From a mechanistic point of view, the weak fluorescence emission, together with the low energy of the triplet excited state compared to the carbon-chlorine bond dissociation energy ( ca. $95 \mathrm{kcal} \mathrm{mol}^{-1}$ ) and the lack of 


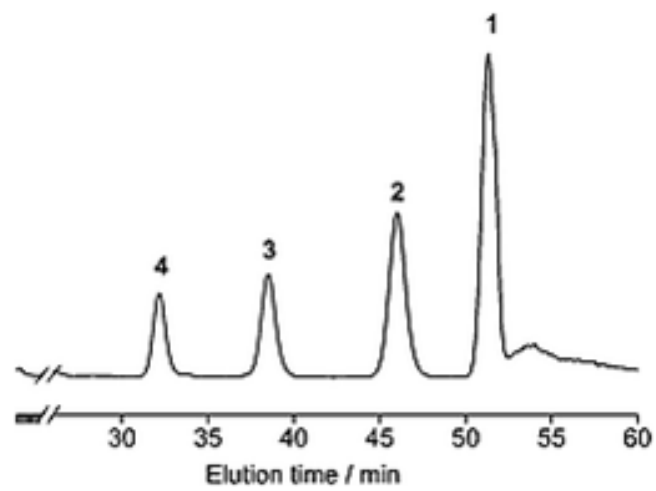

Figure 4.5: HPLC pattern obtained during UVB irradiation of 1 in acetonitrile. The peaks are marked with the numbers corresponding to the structures given in Figure 4.1.
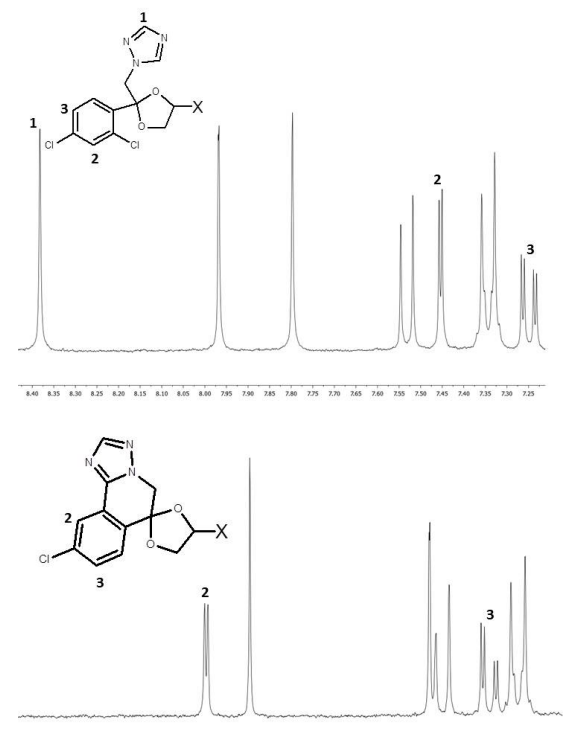

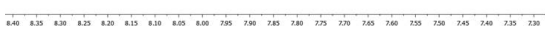

Figure 4.6: ${ }^{1} \mathrm{H}$-NMR differences between 1 and 2: disappearance of triazole hydrogen signal at $8.40 \mathrm{ppm}$ and shift of the phenyl hydrogens

quenching by oxygen point to the involvement of the singlet excited state. The resulting phenyl radical $\left(\mathbf{1}^{\bullet}\right)$ would abstract hydrogen from acetonitrile or undergo an intramolecular reaction leading to alkylation of the triazole moiety, giving rise to the formation of $\mathbf{2}$ (see Figure 4.10A). The poor mass balance indicated a substantial degree of polymerization. Photodegradation quantum yield of $\mathbf{1}$ was found to be 0.20 . 


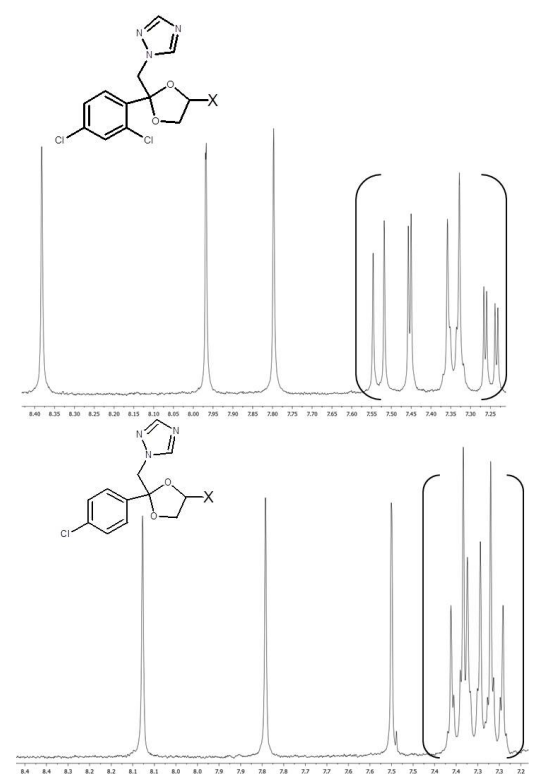

Figure 4.7: ${ }^{1} \mathrm{H}$-NMR differences between 1 and 3: Substitution of chlorine atom at second position of phenyl ring by a hydrogen atom leads to a more symmetric distribution of the phenyl signals.

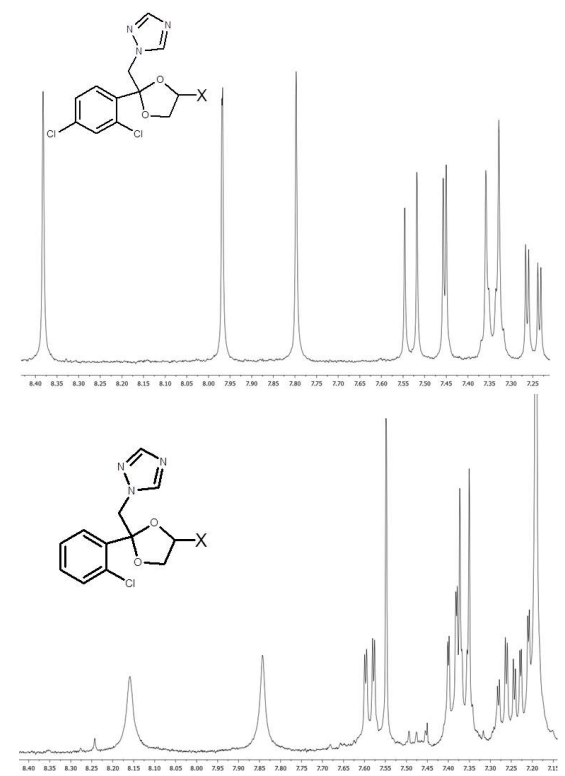

Figure 4.8: ${ }^{1}$ H-NMR differences between 1 and 4: Substitution of chlorine atom at position 4 of the phenyl ring by a hydrogen atom is revealed by the appearance of doublets with hyperfine structure. 


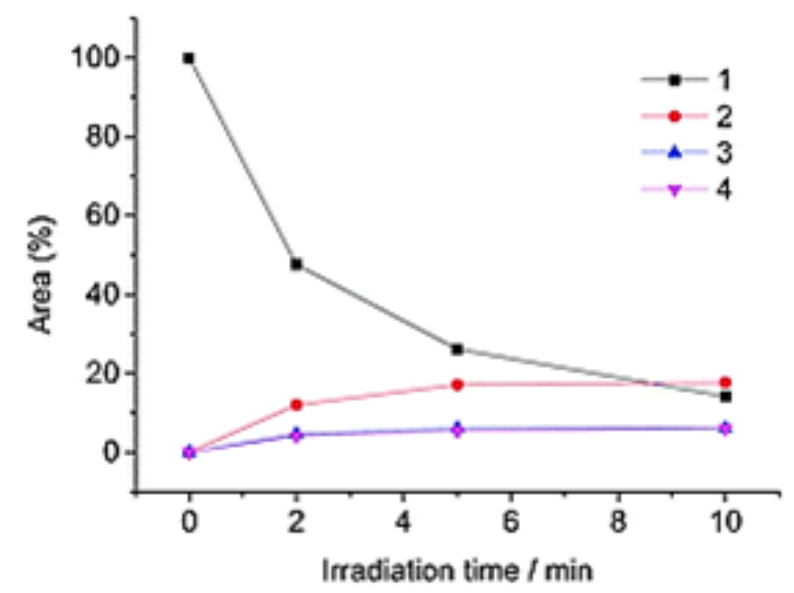

Figure 4.9: Relative areas of 1 and its photoproducts 2,3,4 determined by HPLC (monitored at $254 \mathrm{~nm}$ ), plotted as a function of reaction time. Irradiations were performed in ACN under UVB irradiation.

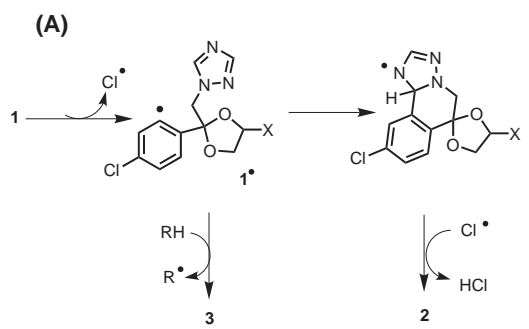

$\mathrm{RH}=\mathrm{EtOH}$ or biomolecule $(\mathrm{BH})$

(B)

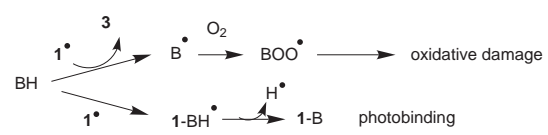

Figure 4.10: (A) Mechanistic scheme for photodecomposition of 1 in different media. (B) Potential photoreactivity of 1 with biomolecules.

\subsubsection{Type I photooxidation mediated by itraconazole}

The whole scenario could change in the presence of good $\mathrm{H}$ donors, as illustrated in the literature for the nonsteroidal antiinflammatory drugs carprofen and diclofenac $[23,28]$. In these cases, photodechlorination was proposed to be the key process from a toxicological point of view. Thus, C-Cl cleavage would be the source of highly reactive radicals, which for carprofen and diclofenac (through its cyclized photoproduct) were demonstrated to be in the origin of photohemolysis and photodynamic lipid peroxidation. In fact, aryl radicals are able to abstract hydrogen from lipids, mediating their peroxidation by a Type I mechanism[23, 28, 50]. 
To check this possibility, irradiation of $\mathbf{1}$ was performed in ethanol, under air, as model for biological media with H-donating ability. Unfortunately, ethanolwater mixtures could not be used, for solubility limitations. The kinetics of drug photodegradation in ethanol, shown in Figure 4.11, revealed a much lower degree of polymerization and a change in photoproducts distribution. Indeed, $\mathbf{3}$ was now formed as the major product, whereas markedly smaller amounts of the cyclized compound 2 were obtained (Figure 4.11). These results are in agreement with the potential for $\mathrm{H}$ abstraction of radical $\mathbf{1}^{\bullet}$, a process which leads mainly to the reduced compounds $\mathbf{3}$ and $\mathbf{4}$. This strongly suggests that itraconazole could act as a Type I photosensitizer towards biomolecules, being potentially in the origin of harmful photobiological processes like lipid photoperoxidation, photohemolysis, and oxidative damage to DNA or protein.

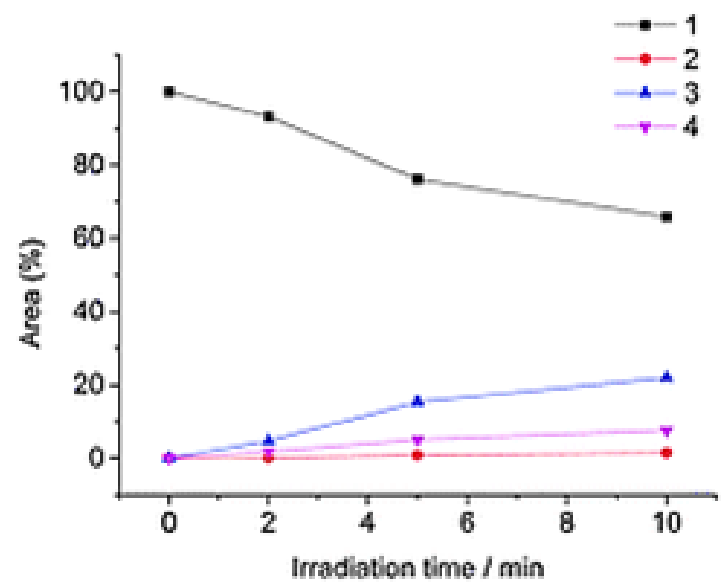

Figure 4.11: Relative areas of 1 and its photoproducts 2,3 and $\mathbf{4}$ determined by HPLC (monitored at $254 \mathrm{~nm}$ ), plotted as a function of reaction time. Irradiations were performed in EtOH under UVB irradiation.

\subsubsection{Dyads as biomodels}

Dyads are useful models to evaluate the effects of stereochemistry, interchromophore distances, diffusion or steric hindrance. Here, two cases of dyads combining a drug moiety and a biological component have been selected to illustrate their usefulness to go deep into the mechanistic detail of photosensitization, especially for Type I process.

The first case deals with photooxidation of $\alpha$-cholesterol $(\alpha \mathrm{Ch})$ or $\beta$-cholesterol $(\beta \mathrm{Ch})$ by ketoprofen $(\mathbf{K P})$. The importance of steric effects has been demonstrated by the lack of photoreactivity of the $\beta$-Ch-KP dyad due to the extended conformation between the two parts. By contrast, the $\alpha$ isomer is highly reactive and 


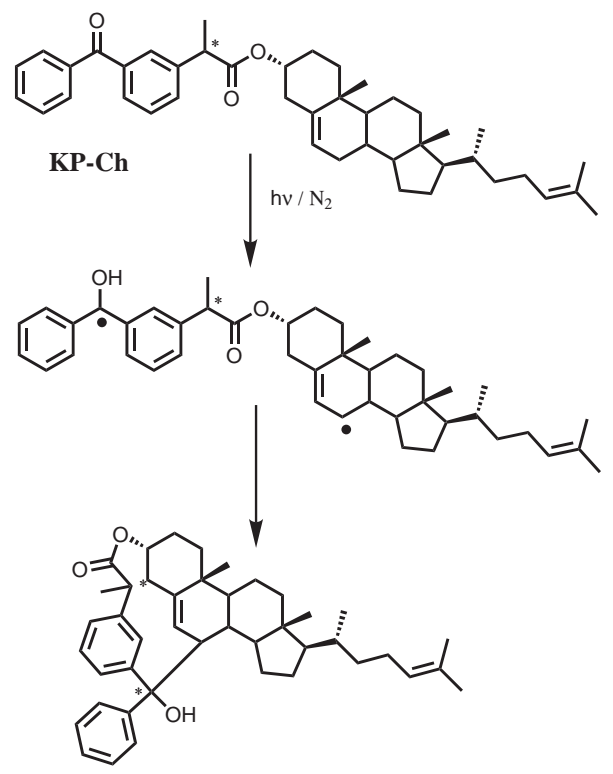

Figure 4.12: Dyad KP- $\alpha \mathrm{Ch}$ and formation of photoproduct upon photolysis.

gives rise to two cyclic photoproducts through $\mathrm{H}$-abstraction from $\mathrm{H} 7$ of $\alpha \mathrm{Ch}$ by the $n \pi^{*}$ triplet excited state of KP and recombination of the obtained biradical (Figure 4.12). Moreover, a clear difference has been observed between the two isomers of KP. In fact, the dyad between R-(KP) and $\alpha$-cholesterol was more photoreactive than dyad with the S-isomer [51].

As a second example, carprofen (CRP) is able to photobind HSA. In this case the candidate substrate for the reaction is the tryptophan ( $\mathbf{T r p}$ ) amino acid located in site I pocket of the protein. To mimic this reaction, a dyad between the drug and tryptophan has been studied (Figure 4.13). Fluorescence and LFP experiments have revealed the occurence of an electron transfer between Trp and excited CRP. Moreover, a stereodifferentiation has been evidenced, with a higher reactivity for the R-CRP isomer [52] .

\subsubsection{Photobinding of itraconazole to model biomolecules}

As mentioned above, irradiation of $\mathbf{1}$ in acetonitrile leads to a primary photodehalogenation process followed by radical cyclization onto the triazole moiety. This reaction pathway is reminiscent of covalent photobinding between drugs and proteins, which is the triggering step of photoallergy[53-55]. Thus, the attention was focused on the ability of radical $\mathbf{1}^{\bullet}$ to react with proteins, and in particular with the aromatic amino acid residues, for instance the indole heterocycle of Trp. With this aim, a model dyad (5) was designed by linking Trp methyl ester with 2,4- 


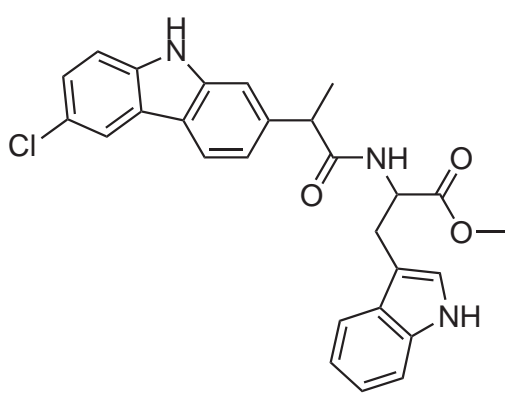

Figure 4.13: Dyad CRP-Trp.

dichlorophenylacetic acid, which contains the reactive moiety of $\mathbf{1}$ (Figure 4.14). As a matter of fact, steady state photolysis of aerated acetonitrile solutions of $\mathbf{5}$ at the absorption maximum $(230 \mathrm{~nm})$, gave rise to formation of a major photoproduct. Its analysis by HRMS revealed a $\mathrm{m} / z$ 369.1002, which corresponds to the loss of $\mathrm{HCl}$. After isolation by preparative HPLC and analysis by NMR spectroscopy $\left({ }^{1} \mathrm{H}\right.$, ${ }^{13} \mathrm{C}$ NMR and HMQC), the structure was unambiguously assigned to the cyclized compound 6 (Figure 4.15). These findings reveal that the aryl radical generated upon homolysis of the $\mathrm{C}-\mathrm{Cl}$ bond in the dihalophenyl moiety of $\mathbf{1}$ can in principle arylate reactive amino acid residues of proteins leading to the formation of covalent photoadducts.

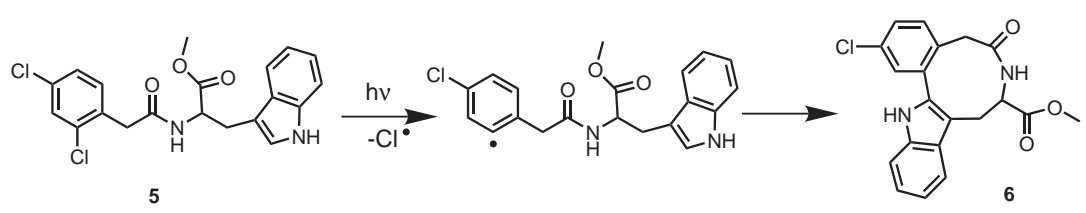

Figure 4.14: Photoreactivity of the model dyad 5.

Overall, itraconazole has demonstrated to be photolabile under UVB irradiation. The study of its photochemical and photophysical properties has provided mechanistic insight into the reported in vivo photosensitivity side effects[42].

Thus, characterization of the photoproducts has revealed a primary dehalogenation process taking place mainly from the ortho position of the dihalogenated phenyl moiety. As detailed in Figure 4.10A, in a poor hydrogen donating medium as acetonitrile the generated radical $\mathbf{1}^{\bullet}$ attacks the triazole ring to form a cyclized intermediate, which finally gives rise to compound 2. Essentially, a parallel behavior would be expected in aqueous medium, in the absence of a hydrogen source. Conversely, the presence of a good hydrogen donor (RH, Figure 4.10A) disfavors the cyclization process; in this case, the main reaction pathway corresponds to $\mathrm{H}$ abstraction by $\mathbf{1}^{\bullet}$, leading mainly to formation of the ortho-dechlorinated compound 3 .

From a toxicological point of view, the photosensitization mechanisms may 

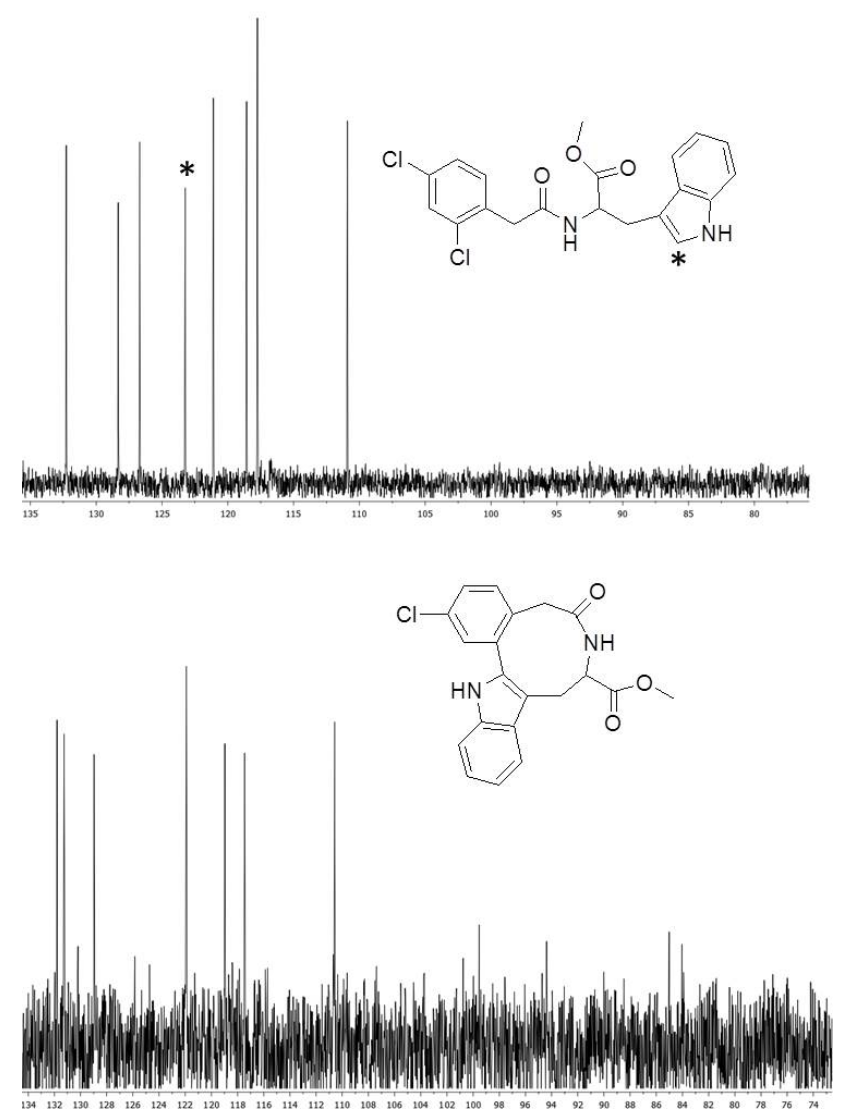

Figure 4.15: DEPT ${ }^{13} \mathrm{C} \mathrm{NMR}$ of 5 and 6: disappearance of $\mathrm{CH}$ signal due the cyclization at the C2 position of indole moiety.

involve a direct interaction between drugs and biological substrates (Type I) or energy transfer from their triplet state to molecular oxygen, generating singlet oxygen (Type II). In this case, the latter process seems unlikely, since the triplet excited state of $\mathbf{1}$ was not detected by laser flash photolysis. However, the reactivity of radical $\mathbf{1}^{\bullet}$ is relevant for its potential to act as a type I photosensitizer (Figure 4.10B), and indeed, its capability to photooxidize biological targets like lipids, DNA or proteins is strongly suggested by the observed H-abstraction from ethanol. Direct reaction of $\mathbf{1}^{\bullet}$ with oxygen seems unlikely, in view of the short lifetime of aryl radicals and the moderate concentration of oxygen in aerated solutions (in the $\mathrm{mM}$ range). After formation of biomolecule-derived radicals $\left(\mathbf{B}^{\bullet}\right)$, reaction with oxygen would lead to unstable peroxides $\left(\mathbf{B O O}^{\bullet}\right)$ and ultimately to oxidation of the biological substrate. Such a process, already reported in the literature for structurally related compounds (DCF or CRP), has been recognized to be responsible for drug-induced phototoxicity (see Introduction chapter). Alternatively, 
radical $1^{\bullet}$ could attack a suitable biomolecule component, to form a covalent bond. This type of drug-protein photoaddition (1-B, Figure 4.10B) was anticipated from radical attack to the triazole ring giving rise to the cyclized photoproduct $\mathbf{2}$. Experimental evidence supporting this mechanism was obtained by the study of model dyad $\mathbf{5}$, where a primary dehalogenation step leads to formation of a covalent bond between the dihaloaromatic reactive moiety and the tryptophan ring, giving rise to compound 6. In line with this result, photobinding of the nonsteroidal antinflammatory agent carprofen to human serum albumin has been identified as the key photochemical process involved in the photoallergy elicited by this drug $[52,56]$.

\subsection{Conclusions}

The present study has demonstrated the potential of antifungal azoles as photosensitizers of biomolecules. Itraconazole is not stable under UVB irradiation. Its photodehalogenation leads to formation of a biologically reactive aryl radical, which could be in the origin of the itraconazole potential to induce phototoxicity by a Type I photooxidation process or photoallergy through covalent photobinding to proteins.

\subsection{Experimental part}

In this section the specific experimental procedure for this chapter are described. General experimental procedures, like UV-Vis absorption spectra or emissions, are described in detail at the general experimental chapter 7 .

\subsubsection{Chemicals}

Itraconazole (1), 2,4-dichlorophenylacetic acid and L-tryptophan methyl ester were from TCI Europe. N'-(3-Dimethylaminopropyl)-N-ethylcarbodiimide hydrochloride (EDC), 1-hydroxybenzotriazole (HOBt), N-methyldiphenylamine (MDPA) and carprofen (CRP) were from Sigma-Aldrich. MDPA was distilled under reduced pressure before using it. The reagent grade solvents were obtained from Scharlau and used without further purification.

\subsubsection{Photolysis of 1}

Irradiation of $1(5 \mathrm{mg} / \mathrm{mL})$ was performed in ethanol or acetonitrile, under aerobic atmosphere, by means of a multilamp photoreactor equipped with UVB lamps (Hitachi, F15T8/BL, maximal output at $c a .300 \mathrm{~nm}$ ). The photoreactions were monitored by high-performance liquid chromatography using a reverse phase column (C18 Mediterranea, $25 \times 1.0 \mathrm{~cm}$, acetonitrile/water, 60/40, v/v). A fixed wavelength of $254 \mathrm{~nm}$ was used for detection.

Degradation quantum yield of $\mathbf{1}$ was determined using MDPA as an external actinometer $(\Phi=0.45$ in acetonitrile) $[57,58]$. Freshly prepared aerated solution of 
1 and MDPA in acetonitrile ( $4 \mathrm{~mL}$ quartz cells) were irradiated in parallel using monochromatic $300 \mathrm{~nm}$ light $\left(\mathrm{A}_{300}=0.50\right)$, by means of a Microbeam system (model L-201), including a $150 \mathrm{~W}$ xenon lamp coupled with a monochromator (model 101). Aliquots were collected at different irradiation times and analyzed by HPLC (detection $262 \mathrm{~nm}$ ). Concentration versus irradiation time plots were obtained using additional calibration curves. Then, degradation quantum yield of $1\left(\Phi_{1}\right)$ was determined from the ratio of the slopes of the degradation profiles, according to eqn (4.1)

$$
\Phi_{1}=\frac{\text { Slope }_{1}}{\text { Slope }_{M D P A}} \times \Phi_{M D P A}
$$

Where $S_{\text {Slope }}$ and Slope $_{M D P A}$ correspond to the linear fittings of the concentration versus time irradiation experiments and $\Phi_{M D P A}$ is the degradation quantum yield of the reference.

\subsubsection{Isolation and identification of photoproducts $2-4$}

Isolation of the photoproducts was carried out using a reverse phase column C18 Kromasil 100, $25 \times 2.5 \mathrm{~cm}$, acetonitrile/water, 60/40, v/v. Ammonium hydroxide was added at every collected fraction until $\mathrm{pH} 9$, and then the fractions were dried at reduced pressure. Characterization was achieved by NMR and HRMS analysis (see appendix A). ${ }^{1} \mathrm{H}$ and ${ }^{13} \mathrm{C}$ NMR spectra of the parent drug have been previously described in the literature[59].

\subsubsection{Synthesis of the model dyad 5}

2,4-Dichlorophenylacetic acid $\left(75 \mathrm{mg}, 3.65 \times 10^{-4} \mathrm{~mol}\right)$, L-tryptophan methyl ester $\left(108 \mathrm{mg}, 4.26 \times 10^{-4} \mathrm{~mol}\right)$, EDC $\left(81.7 \mathrm{mg}, 4.26 \times 10^{-4} \mathrm{~mol}\right)$, and HOBt $(200$ $\left.\mathrm{mg}, 4.26 \times 10^{-4} \mathrm{~mol}\right)$ were mixed in dry DMF $(10 \mathrm{~mL})$, and the mixture was stirred overnight. Then, the solution was treated with $10 \% \mathrm{HCl}$ and extracted with ethyl acetate. The organic phase was washed 3 times with water and twice with saturated sodium bicarbonate and then dried over sodium sulfate. The residue was dried under vacuum to give a yellowish solid. Characterization was performed by means of NMR and HRMS (ESI ${ }^{+}$) analysis.

\subsubsection{Isolation and identification of photoproduct 6}

Compound $5\left(1.460 \mathrm{~g}, 3.6 \times 10^{-3} \mathrm{~mol}\right)$ was dissolved in acetonitrile/water $2 / 1$, $\mathrm{v} / \mathrm{v}(400 \mathrm{~mL})$, and irradiated under aerated conditions at $230 \mathrm{~nm}$ for $45 \mathrm{~min}$ (Microbeam L-201 system including a $150 \mathrm{~W}$ Xe lamp and a L-101 monochromator). Next, the solution was concentrated under vacuum and re-dissolved in ethyl acetate. The organic phase was washed with brine and concentrated. Isolation of the main photoproduct was performed by column chromatography with a gradient of hexane/ethyl acetate; final purification was carried out using a reverse phase column (C18 Kromasil 100, $25 \times 2.5 \mathrm{~cm}$ ), using acetonitrile/water, 60/40, v/v as 
eluent. Characterization was performed by means of NMR and HRMS $\left(\mathrm{ESI}^{+}\right)$ analysis. 


\section{Chapter 5}

\section{Photosensitization by Imatinib*}

\subsection{Introduction}

Imatinib (IMT, Figure 5.1) is a first line therapy agent that specifically targets tyrosine kinases, which are central proteins in the pathogenesis of human cancer[6063]. This promising drug (Gleevec ${ }^{\circledR}$ or Glivec ${ }^{\circledR}$ ), approved by the FDA in 2001 , was designated as a "magic bullet" and was recognized for its capacity to deal with fatal cancers converting them into manageable chronic conditions[60-62, 64]. It is widely prescribed for the treatment of Philadelphia chromosome-positive chronic myeloid leukemia (CML) or gastrointestinal stromal tumors (GIST) and has also proven its efficacy in other neoplastic diseases[60-63]. It has been reported that IMT inhibits three tyrosine kinases with a high degree of specificity: the Abelson cytoplasmic tyrosine kinase (Abl) activated in CML, the c-Kit tyrosine kinase for GISTs and some melanomas, and the platelet derived growth factor receptors (PDGFR) kinase [63, 65]. Tyrosine phosphorylation of proteins involved in signal transduction and initiation of the cascade responsible for cancer development are prevented, interrupting this way the growth of cancer cells[62].

Interestingly, IMT has emerged from rational drug design based on in vitro assays, in a successful attempt to optimize the chemical structure on the basis of isolated protein kinase inhibition $[62,64,65]$. The first step allowed identifying 2-phenylaminopyrimidine as an inhibitor of hyperactive Abl protein by high throughput screening of chemical libraries. Afterwards, this lead compound, which exhibited low potency and poor specificity but constituted an attractive scaffold for further development, was optimized by the attachment of a 3-pyridyl group at the $\mathrm{C} 4$ position of the pyrimidine in order to improve cellular activity. Sub-

${ }^{*}$ Reproduced in part with permission from: Photosensitization by imatinib. A photochemical and photobiological study on the drug and its substructures, Giacomo Nardi; Virginie LhiaubetVallet; Miguel A. Miranda, Chem.Res.Toxicol., 2014, 27, 1990-1995. Copyright 2014 American Chemical Society. 


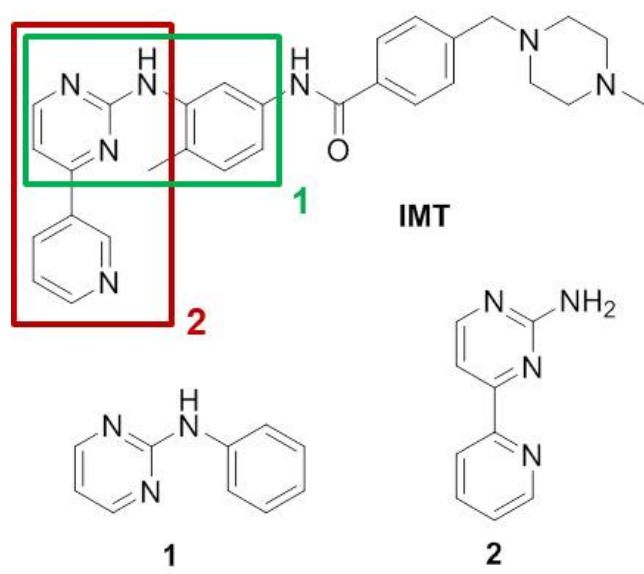

Figure 5.1: Structure of IMT and some of its potentially photoactive substructures

sequently, introduction of a benzamide moiety led to a modest activity against $\mathrm{Abl}$ and PDGFR tyrosine kinases, which was markedly enhanced by appending a methyl group at the C6 position of the aniline ring. Finally, solubility, oral bioavailability, metabolism and excretion were improved by introduction of the Nmethylpiperazine side chain[62, 64, 65].

Cutaneous reactions are among the most common nonhematological side effects of IMT [66-70]. They include increased photosensitivity[66, 71, 72], photoinduced dermatitis[72], pseudoporphyria[68, 69, 73], or squamous cell carcinoma[74]. The occurrence of these adverse effects only in long-term treated patients suggests that the cumulative dosage is determinant for photosensitization[71]. However, the molecular bases have not been unveiled yet, and different scenarios have been proposed. One of them is that IMT impairs melanogenesis via inhibition of c-Kit enzyme activity, thereby leading to hypopigmentation and thus altering the natural skin protection against UV exposure[66, 68, 71]. Drug-induced photosensitivity has also been associated with ATP-binding cassette transporter ABCG2 inhibition leading to accumulation of endogenously produced porphyrins and pheophorbide $\mathrm{A}$ in the systemic blood circulation [75, 76]. Interestingly, photodynamic therapy studies have taken advantage of this apparent drawback by coadministering IMT, thus allowing photosensitizer accumulation in tumor cells[77].

In the case of photosensitizing drugs, their intrinsic photoreactivity and their excited state interactions with key biomolecules are of paramount importance. However, to our knowledge only one work has previously dealt with IMT photobehavior, reporting a remarkable photostability after $72 \mathrm{~h}$ of light exposure[78]. This is surprising, as the drug contains potentially photoactive moieties such as the anilino-pyrimidine and the pyridyl-pyrimidine substructures (framed in green and red, respectively, Figure 5.1). The former is closely related to pyrimethanil, a pho- 
tolabile fungicide whose irradiation gives rise to formation of eight photoproducts[79], whereas the latter should also be photoreactive by analogy to biphenyl and its derivatives, which exhibit well-characterized singlet and triplet excited states and a solvent-dependent intersystem crossing quantum yield[38, 80, 81].

With this background, the aim of the present work is to investigate the photobehavior of IMT and its main building blocks, with special emphasis on the DNA photosensitizing potential. For this purpose, IMT and its model compounds 1 and 2 (Figure 5.1) have been submitted to steady-state and time-resolved fluorescence, as well as laser flash photolysis (LFP) studies. Formation of DNA damage has been examined by detection of single strand breaks (SSB) using agarose gel electrophoresis.

\subsection{Results and discussion}

\subsubsection{Photogenotoxicity of imatinib and its substructures}

In order to evaluate the potential of IMT, 1 and $\mathbf{2}$ as DNA photodamaging agents, supercoiled DNA (pBR322) was UVA-irradiated in the presence and in the absence of the three compounds. After agarose gel electrophoresis, the native supercoiled (Form I) was separated from circular DNA (Form II) resulting from single strand breaks (SSB). As shown in Figure 5.2, DNA Form II increased with irradiation time in the presence of $\mathbf{2}$, whereas no significant changes were observed in the case of $\mathbf{1}$, IMT or the DNA control. These results reveal that the drug itself is not a DNA-photosensitizer, while one of its substructures displays a marked photogenotoxic potential.

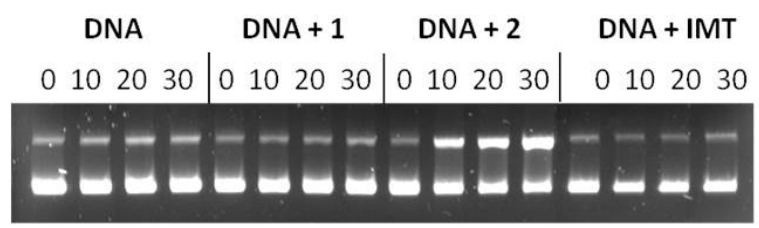

Figure 5.2: Agarose gel electrophoresis of supercoiled DNA (pBR322, $20 \mu \mathrm{M}$ ) irradiated for 0-30 min alone and in the presence of $\mathbf{1 , 2}$ or IMT $(220 \mu M)$

\subsubsection{Photophysical studies}

The attention was first focused on the photophysical properties of the parent drug. As shown in Figure 5.3, its absorption spectrum exhibits two maxima peaking at 230 and $275 \mathrm{~nm}$, together with a tail reaching the UVB-UVA region. This long-wavelength absorption is an important requirement for photosensitizing agents, as it is responsible for their interaction with solar radiation. Indeed, light absorption leads to population of excited states that can mediate damage to biomolecules. However, neither the singlet nor the triplet excited state could 
be detected by fluorescence or LFP measurements, respectively (data not shown). This is consistent with the lack of DNA-photosensitization by IMT.

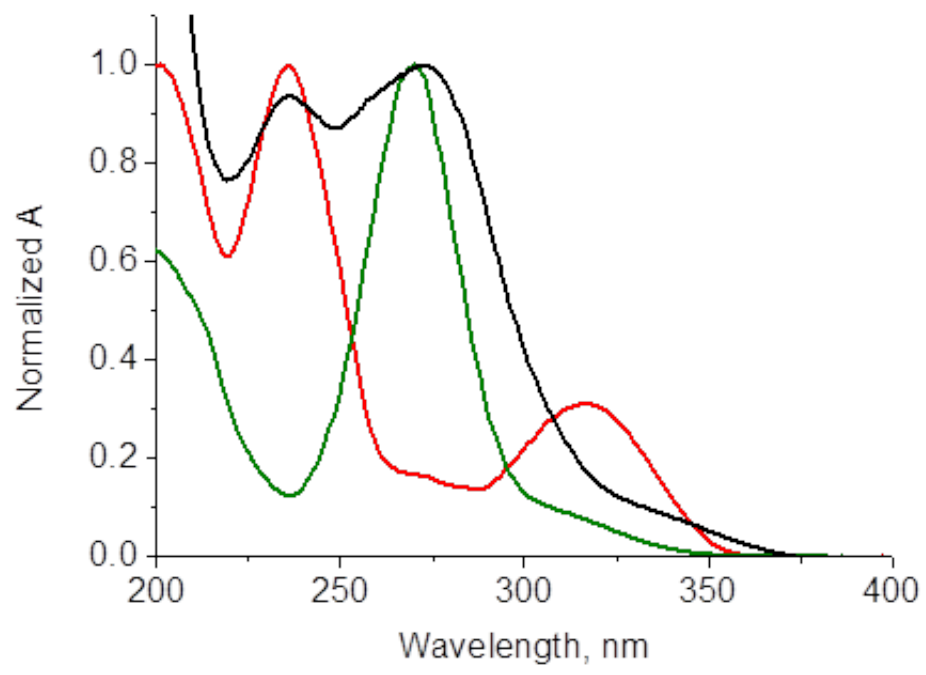

Figure 5.3: UV absorption spectra of IMT (black) and compounds 1 (green) and 2 (red) in acetonitrile

Then, the photophysical properties of the substructures, starting with 2-phenylaminopyrimidine (1) were considered. The absorption spectrum displayed a main band centered at ca. $270 \mathrm{~nm}$ together with a shoulder extending up to ca. $350 \mathrm{~nm}$ (Figure 5.3). The fluorescence emission was characterized by a maximum at ca. $445 \mathrm{~nm}$ (Figure 5.4A). A singlet excited state energy $\left(\mathrm{E}_{S}\right)$ of ca. $78 \mathrm{kcal}$ $\mathrm{mol}^{-1}$ was obtained from the intersection between normalized emission and excitation spectra. Moreover, transient absorption spectra obtained after LFP (308 $\mathrm{nm}, \mathrm{Xe}: \mathrm{Cl}$ excimer laser) revealed the presence of two bands (Figure 5.5A). The minor species with a maximum at $360 \mathrm{~nm}$ and a lifetime of $10 \mu \mathrm{s}$ in deaerated acetonitrile was weakly quenched by oxygen $\left(k_{q}=7.3 \times 10^{7} \mathrm{M}^{-1} \mathrm{~s}^{-1}\right)$. By contrast, the major, long wavelength band starting at $500 \mathrm{~nm}$ and extending beyond $700 \mathrm{~nm}$ was much shorter-lived $(0.34 \mu \mathrm{s})$, and its quenching by oxygen occurred much faster $\left(k_{q}=6 \times 10^{9} \mathrm{M}^{-1} \mathrm{~s}^{-1}\right)$; hence, it was tentatively assigned as a triplet excited state $\left({ }^{3} \mathbf{1}^{*}\right)$. In order to confirm the nature of this transient, parallel experiments were performed in the presence of biphenyl and $\beta$-carotene $(\beta \mathbf{C})$ as energy acceptors; their triplet energies are $\mathrm{E}_{T}=65 \mathrm{kcal} \mathrm{mol}^{-1}$ and $20 \mathrm{kcal} \mathrm{mol}^{-1}$, respectively[38]. The former does not absorb $308 \mathrm{~nm}$ light, whereas the latter has an extremely inefficient intersystem crossing $\left(\Phi_{T}<0.001\right)[38]$; thus under the employed LFP conditions the triplet excited states can only be populated by photosensitization. In both cases, typical triplet bands were indeed observed (Figure 5.5B) after nearly diffusion-controlled energy transfer from ${ }^{3} \mathbf{1}^{*}\left(k_{E T}=10 \times 10^{10} \mathrm{M}^{-1} \mathrm{~S}^{-1}\right)$. Moreover, 
as shown in Figure $5.5 \mathrm{C}$, the growth of the characteristic ${ }^{3} \beta \mathbf{C}^{*}$ signal matched with the decay of $\mathbf{3}^{\mathbf{3}}$. Overall, the above results allowed safe assignment of the long wavelength transient absorption as ${ }^{\mathbf{3}} \mathbf{1}^{*}$, whose energy must be above that of biphenyl.
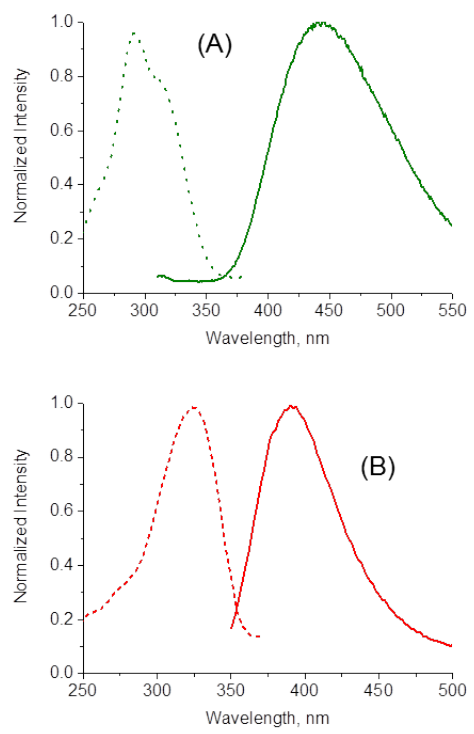

Figure 5.4: Fluorescence emission (full line) and excitation (dotted line) spectra of compound 1 at $\lambda_{\text {exc }}=280 \mathrm{~nm}(A)$ and compound 2 at $\lambda_{e x c}=328 \mathrm{~nm}(B)$ in acetonitrile solution

Thus, compound $\mathbf{1}$ is capable of generating a potentially photoactive triplet excited state; however it does not show a significant photogenotoxic potential in the SSB assay. This can be attributed to the short lifetime (submicrosecond) of ${ }^{\mathbf{3}} \mathbf{1}^{*}$. Interestingly, during optimization of IMT design it has been demonstrated that introduction of a 6-methyl group, denominated the flag methyl, affects the conformation of the molecule[82]. This change is associated with a better specificity of IMT by suppressing the inhibition of serine/tyrosine kinases while enhancing that of the PDGF kinase. From a photophysical point of view, this structural change led to blocking of the fluorescence emission and to the absence of any transient species in the LFP spectrum (data not shown), resulting in an enhanced photosafety.

Finally, the photobehavior of compound $\mathbf{2}$ was addressed. The absorption spectrum obtained in acetonitrile displayed two main bands, one in the UVC at $240 \mathrm{~nm}$ and the other one in the UVB/UVA region peaking at ca. $320 \mathrm{~nm}$ (Figure 5.3). The emission measurements revealed a maximum at ca. $390 \mathrm{~nm}$ (Figure 5.4B), and a fluorescence quantum yield of 0.23 using pyrene $\left(\Phi_{F}=0.72\right)$ as standard[38]. A singlet excited state energy $\mathrm{E}_{S}=81 \mathrm{kcal} \mathrm{mol}^{-1}$ was determined from the intersection between the excitation and emission bands (Figure 5.4B). As regards 

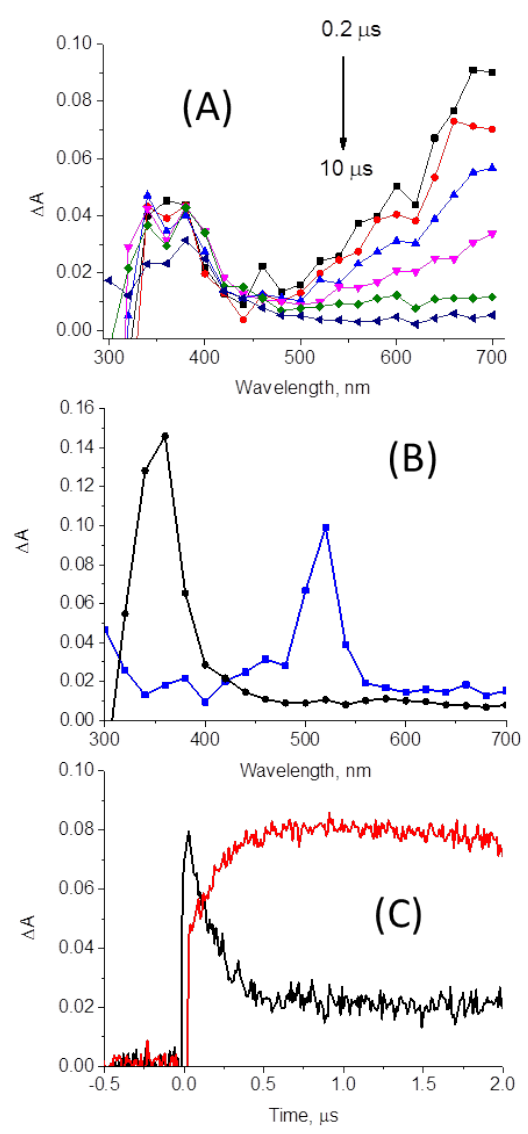

Figure 5.5: (A) Transient absorption spectra of compound 1 in deaerated acetonitrile obtained at different times after the laser pulse at $308 \mathrm{~nm}$. (B) Transient absorption spectra $0.8 \mu$ s after the laser pulse of $\mathbf{1}$, in the presence of $1500 \mu \mathrm{M}$ biphenyl (black) or $33 \mu M \beta$-carotene (blue). (C) Decay at $700 \mathrm{~nm}$ and growth at $520 \mathrm{~nm}$ for a solution of 1 in the presence of $\beta$-carotene $(33 \mu \mathrm{M})$

LFP (Figure 5.6A), transient absorption spectra of $\mathbf{2}$ in acetonitrile exhibited two bands at 320 and $420 \mathrm{~nm}$, which decayed with the same lifetime of ca. $5 \mu \mathrm{s}$. This species was ascribed to the triplet excited state $\left({ }^{3} \mathbf{2}^{*}\right)$ based on its photosensitized formation from xanthone (Figure 5.6B) and on its efficient quenching by oxygen and $\beta \mathbf{C}$ (Figure 5.6C).

Thus, compound $\mathbf{2}$ is photoactive and possesses a long-lived triplet excited state that can be associated with undesired photosensitization effects. This explains the photogenotoxic potential of $\mathbf{2}$ observed in the SSB assays. Being a substructure of IMT, one could in principle anticipate that the drug itself could also exhibit similar photochemical and photobiological properties as 2; however, this was not confirmed by the experimental results. Clearly, the integration of $\mathbf{2}$ in 

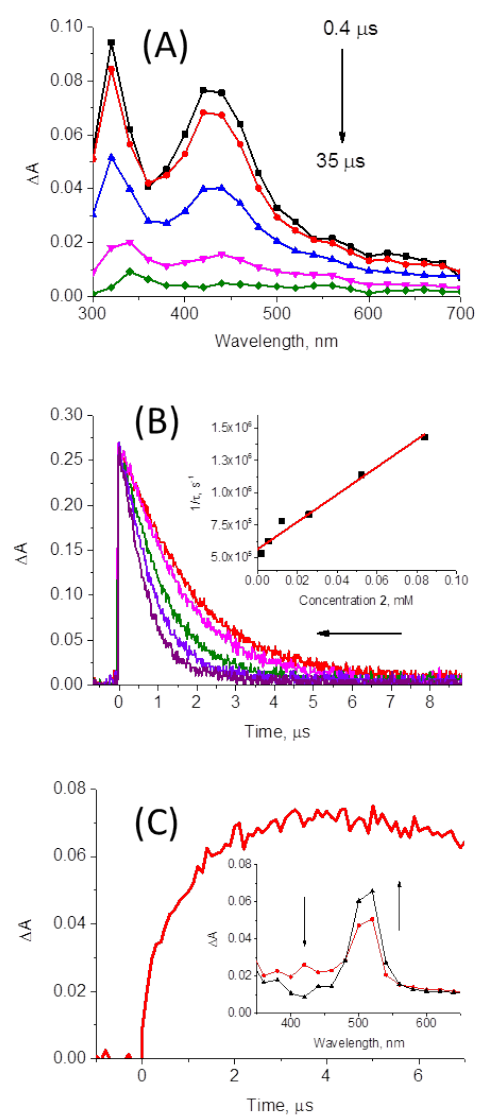

Figure 5.6: (A) Transient absorption spectra of 2 in $N_{2}$-bubbled acetonitrile at different times after $308 \mathrm{~nm}$ laser excitation. (B) Decays of xanthone triplet excited state monitored at $612 \mathrm{~nm}$ in the presence of increasing amounts of 2 (from 0 to $84 \mu \mathrm{M}$ ). Inset: Corresponding Stern-Volmer plot. (C) Growth of the $520 \mathrm{~nm}$ signal upon quenching of $\mathbf{3}^{*}$ by $13 \mu \mathrm{M} \beta \mathbf{C}$. Inset: spectra obtained after 0.40 (red) and 0.65 (black) $\mu \mathrm{s}$

a more complex structure strongly modifies its photobehavior, which in this case is fortunate because it leads to an improved toxicological profile. In order to gain some insight into this intriguing observation, the possibility of an internal quenching was investigated by checking whether the key active species ${ }^{\mathbf{3}} \mathbf{2}^{*}$ could exhibit significant excited state interactions with benzanilide $\mathbf{3}$ (Figure 5.7A), another substructure of IMT. Indeed, when LFP of $\mathbf{2}$ was run in the presence of increasing concentrations of $\mathbf{3}$, a consistent shortening of the triplet lifetime was measured, clearly indicating dynamic quenching (Figure 5.7B). 

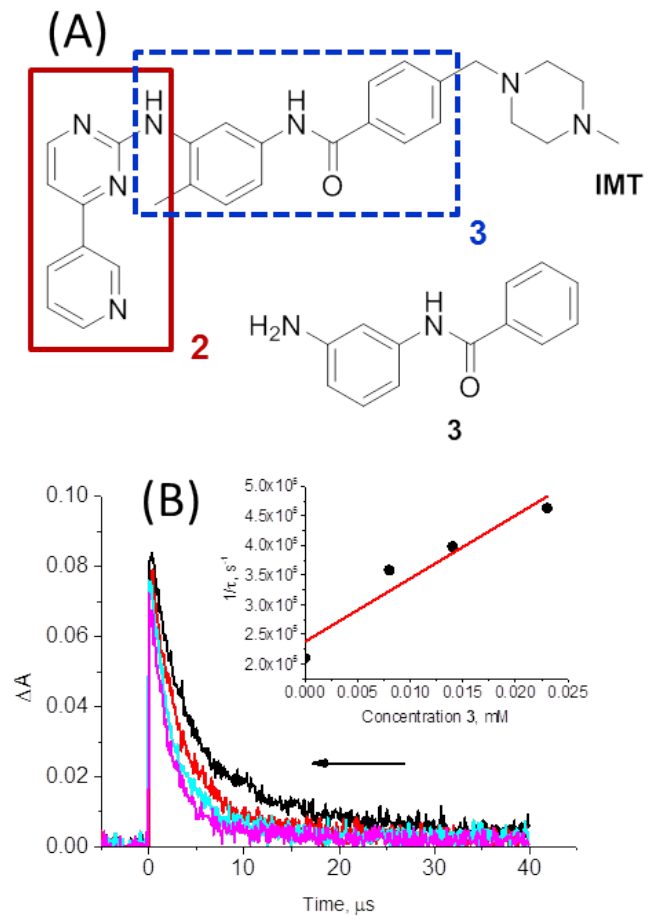

Figure 5.7: (A) Structure of compound 3 and its relationship to IMT. (B) Decays of ${ }^{\mathbf{3}} \mathbf{2}^{*}$ monitored at $420 \mathrm{~nm}$ in the presence of increasing amounts of 3 (from 0 to $23 \mu \mathrm{M}$ ). Inset: Corresponding Stern-Volmer plot 


\subsection{Conclusions}

Imatinib is a tyrosine kinase inhibitor, which has found application in the treatment of some types of cancer. It constitutes a successful example of rational design through appropriate molecular engineering. The chemical structure of this drug contains different fragments that are combined to enhance the pharmacological activity and the pharmacokinetic behavior. As regards the toxicological profile, imatinib has been reported to mediate some undesired side effects, including adverse cutaneous reactions such as enhanced photosensitivity or pseudoporphyria. In this context, two of its substructures are photoactive, namely the aniline-pyrimidine (1) and the pyridyl-pyrimidine (2) moieties. The latter displays a long-lived triplet excited state and exhibits photogenotoxic potential, revealed through photosensitization of single strand breaks in supercoiled DNA. Interestingly, imatinib does not show the photochemical and photobiological behavior of its substructures. Specifically, it does not give rise to a detectable triplet state and does not mediate DNA photodamage. This is attributed to internal quenching of the excited pyridyl-pyrimidine chromophore by the benzanilide fragment. On the bases of the obtained experimental results, direct in vivo photosensitization by imatinib seems unlikely. Instead, the reported photosensitivity disorders could be related to indirect processes, such as the previously suggested impairment of melanogenesis or the accumulation of endogenous porphyrins.

\subsection{Experimental part}

In this section the specific experimental procedure for this chapter are described. General experimental procedures, like UV-Vis absorption spectra or emissions, are described in detail at the general experimental chapter 7 .

\subsubsection{Chemicals}

All reagents were purchased either from Sigma-Aldrich Co. or Kemprotec, Inc. and were used without further purification. Compounds $\mathbf{1}$ and $\mathbf{2}$ were obtained as described $[83,84]$, whereas compound $\mathbf{3}$ was synthesized with a procedure adapted from the literature[85]. Synthesis and characterization of those compound are described at appendix B.

\subsubsection{Agarose gels}

The detailed procedure followed for agarose gel electrophoresis has been described elsewhere[86]. Samples containing supercoiled circular DNA (pBR322; 5 $\mu \mathrm{L} ; 20 \mu \mathrm{M}$ of base-pairs) in the absence or presence of IMT, compound 1 or 2 (5 $\mu \mathrm{L} ; 220 \mu \mathrm{M})$ were used in the electrophoresis experiment. The samples were irradiated using a multilamp photoreactor (Luzchem) with fluorescent tubes emitting in the 300-400 $\mathrm{nm}$ range with a maximum at $355 \mathrm{~nm}$ (LZC-UVA). The samples were then loaded on a $0.8 \%$ agarose gel containing RedSafe ${ }^{\circledR}$. 


\section{Chapter 6}

\section{Scope and limitations of the TEMPO/EPR method for singlet oxygen detection: the misleading role of electron transfer*}

\subsection{Introduction}

Singlet oxygen (molecular oxygen in a ${ }^{1} \Delta_{g}$ state or ${ }^{1} \mathrm{O}_{2}$ ) is one of the most important reactive oxygen species (ROS). Its reactions include oxidation of lipids $[6,87]$, proteins [88-90] and nucleic acids [5, 91, 92], that may trigger a biological damage. This may lead to undesired adverse effects, like drug phototoxicity [4, 93], but it can also be exploited to produce beneficial effects as in photodynamic therapy $[94,95]$.

Production of ${ }^{1} \mathrm{O}_{2}$ by a photosensitizer is a classical example of photoinduced energy transfer: after absorption of light, the photosensitizer reaches its singlet excited state and subsequently crosses to its triplet excited state. Then, the triplet ground state of molecular oxygen $\left({ }^{3} \Sigma_{g}\right)$ is promoted to the ${ }^{1} \Delta_{g}$ state through triplet-triplet energy transfer[96].

For many biological and biomedical studies, it is essential to detect the production of ${ }^{1} \mathrm{O}_{2}$ and its quantification. Among the available methods, detection

*Reprinted from: Scope and limitations of the TEMPO/EPR method for singlet oxygen detection: the misleading role of electron transfer, Giacomo Nardi; Ilse Manet; Sandra Monti; Miguel A. Miranda; Virginie Lhiaubet-Vallet, Free Radic. Biol. Med., 2014, 77, 64-70. Copyright 2014, with permission from Elsevier. 
of the characteristic $1270 \mathrm{~nm}$ phosphorescence of singlet oxygen by time resolved near infrared (TRNIR) emission constitutes the most direct and unambiguous proof $[97,98]$. However, the required equipment is not always available in biochemical laboratories.

An alternative (indirect) method that has been widely applied is the use of electron paramagnetic resonance (EPR) in combination with trapping. Upon reaction with ${ }^{1} \mathrm{O}_{2}$, the trap molecule gives rise to a detectable spin active species with a distinctive line pattern. Thus, detection of TEMPO (2,2,6,6-tetramethyl-1-piperidinyloxyl) free radical can be easily achieved by EPR after the oxidation of TEMP (2,2,6,6-tetramethylpiperidine) with singlet oxygen (Figure 6.1) [39]. Although the TEMPO/EPR method has been largely employed [22, 99-106], a systematic investigation of the scope and limitations of this technique has never been performed, so it is feasible to obtain misleading data. For instance, a possible source of artifacts is the interaction between the excited photosensitizer and TEMP, which is related to the widely described quenching of photosensitizers by amines[1, 107-109].

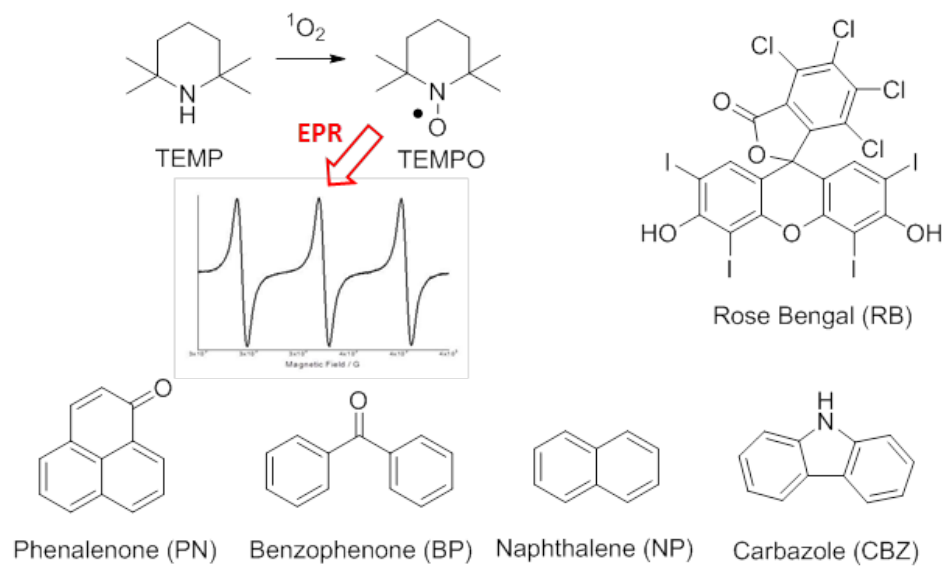

Figure 6.1: Structure of the molecules involved in the study and EPR signal of TEMPO radical.

The aim of the present study is to compare the results obtained by the direct detection (TRNIR method) and by indirect spin trapping (TEMPO/EPR method) for the detection and quantification of singlet oxygen, using a set of well-known photosensitizers. The basis of the TEMPO method and the chemical structure of the selected photosensitizers are shown in Figure 6.1. The obtained results reveal that the method leads to significant overestimation of singlet oxygen production when the singlet or triplet excited state of the photosensitizers are efficiently quenched by TEMP, acting as electron donor. 


\begin{tabular}{cc|c} 
& $\Phi_{\Delta}$ a $/$ TRNIR & $\Phi_{\Delta} /$ EPR \\
\hline Phenalenone & $0.95^{\mathrm{b}}$ & $0.95^{\mathrm{b}}$ \\
Benzophenone & $0.35(0.35)^{\mathrm{c}}$ & 0.50 \\
Naphthalene & $0.56(0.5)^{\mathrm{d}}$ & 0.50 \\
Carbazole & $0.15(0.17)^{\mathrm{e}}$ & 0.21 \\
a in brackets, literature values, & $\mathrm{b}$ as standard \\
see ref [34] c from ref [111] ${ }^{\mathrm{d}}$ from ref [110] \\
e from ref [23]
\end{tabular}

Table 6.1: Singlet oxygen quantum yield of each photosensitizer

\subsection{Results and discussion}

\subsubsection{Determination of singlet oxygen quantum yield by TRNIR or TEMPO/EPR}

Singlet oxygen quantum yields $\left(\Phi_{\Delta}\right)$ were determined for each photosensitizer with both direct method (TRNIR) and indirect method (TEMPO/EPR), by comparison with phenalenone $\left(\phi_{\Delta}=0.95\right)[34]$ (Figure 6.2). The obtained values are reported in Table 6.1. The results of TRNIR direct method are in accordance with literature values $[23,110,111]$. However, the quantum yield of benzophenone evaluated by indirect method TEMPO/EPR was significantly higher. Moreover, upon addition of $50 \mathrm{mM}$ TEMP to the benzophenone solution, the direct TRNIR measurement led to nearly zero quantum yield (Figure 6.2B and Figure 6.3A).

\subsubsection{Effect of added TEMP on singlet oxygen detection by TRNIR}

To investigate the direct effect of TEMP addition on ${ }^{1} \mathrm{O}_{2}$ detection, TRNIR was performed with increasing amounts of TEMP. As shown in Figure 6.3, in the absence of TEMP the ${ }^{1} \mathrm{O}_{2}$ lifetime was $85 \mu \mathrm{s}$, using either phenalenone or benzophenone as photosensitizers, in accordance with the literature value [112]. Depending on the photosensitizer, addition of TEMP to the solution had different consequences: (i) in the case of phenalenone, TEMP acted as a poor quencher, shortening the lifetime of ${ }^{1} \mathrm{O}_{2}$ with $k_{q}=1.3 \times 10^{6} \mathrm{M}^{-1} \mathrm{~s}^{-1}$ [113], a result consistent with the literature value, or (ii) in the case of $\mathbf{B P}$ in addition to lifetime shortening, TEMP was able to knock out the formation of singlet oxygen (Figure 6.3A). The latter observation indicates that there is an interaction between TEMP and the precursor of ${ }^{1} \mathrm{O}_{2}$, namely the excited triplet state of $\mathbf{B P}$. In the case of $\mathbf{P N}$, addition of TEMP did not seem to influence the initial TRNIR intensity of ${ }^{1} \mathrm{O}_{2}$, while it affected the ${ }^{1} \mathrm{O}_{2}$ lifetime (Figure 6.3B). 

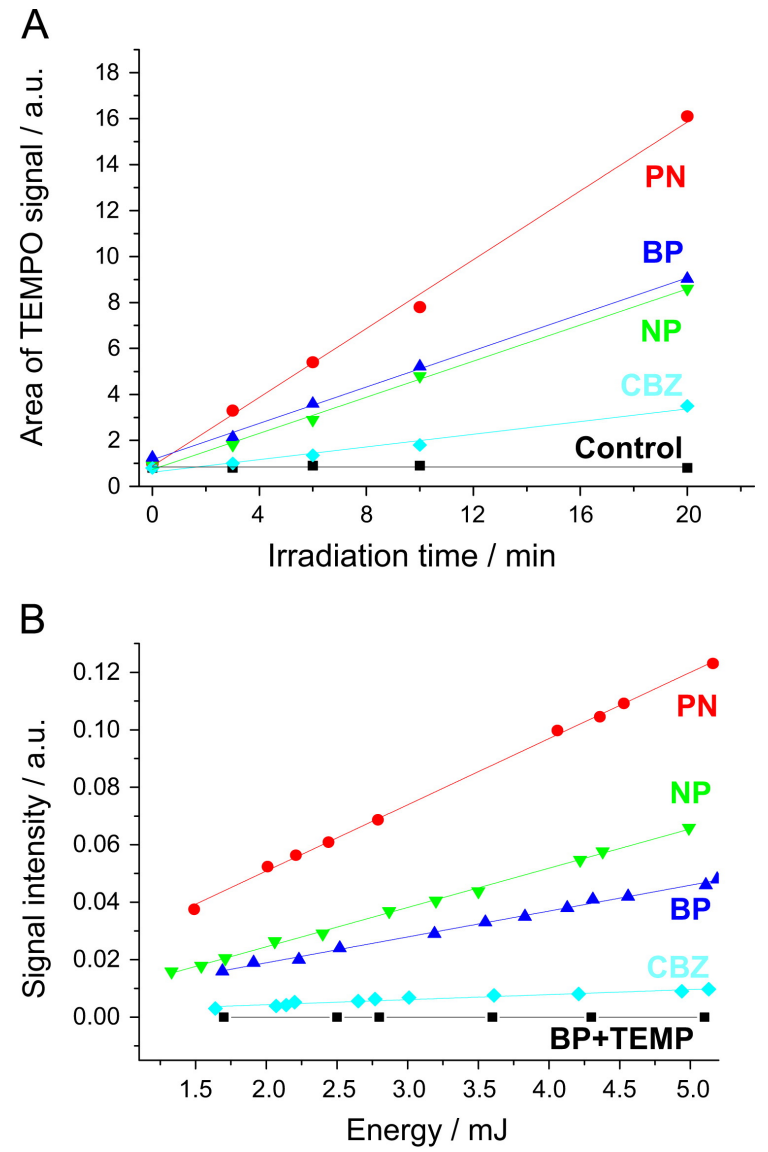

Figure 6.2: Aerated ACN solution of $\mathbf{P N}$ (red), BP (blue), $\mathbf{N P}$ (green) and $\mathbf{C B Z}$ (cyano). (A) Intensity of TEMPO in EPR as a function of irradiation time at $280 \mathrm{~nm}$. In black, ACN solution of $50 \mathrm{mM}$ TEMP. (B) Initial intensity of ${ }^{1} \mathrm{O}_{2}$ TRNIR signal as a function of $266 \mathrm{~nm}$ laser energy. In black, solution of $\mathbf{B P}$ and $50 \mathrm{mM}$ TEMP.

\subsubsection{Quenching of photosensitizer excited states by TEMP}

In view of the effects produced by addition of TEMP on ${ }^{1} \mathrm{O}_{2}$ TRNIR signal, the triplet-triplet transient absorption of the photosensitizers was studied by laser flash photolysis in presence of TEMP. In the case of $\mathbf{B P}$, triplet quenching by TEMP was observed with a rate constant $\left(k_{q}=1.5 \times 10^{9} \mathrm{M}^{-1} \mathrm{~s}^{-1}\right)$ in accordance with literature $[114,115]$. In the case of $\mathbf{P N}$, although TEMP was also able to deactivate the triplet excited state, the measured rate constant was two orders of magnitude lower $\left(k_{q}=8.3 \times 10^{6} \mathrm{M}^{-1} \mathrm{~s}^{-1}\right)$. On the contrary, the rate constants for triplet quenching by oxygen were very similar for the two ketones (ca. $2.5 \times 10^{9}$ $\mathrm{M}^{-1} \mathrm{~s}^{-1}$ ). Taking into account the competition between TEMP and $\mathrm{O}_{2}$, as well as the $\mathrm{k}_{q}$ values and the TEMP and $\mathrm{O}_{2}$ concentrations $(50 \mathrm{mM}$ and $1.9 \mathrm{mM}$, respectively), more than $90 \%$ of triplet $\mathbf{B P}$ is quenched by TEMP, whereas more than 

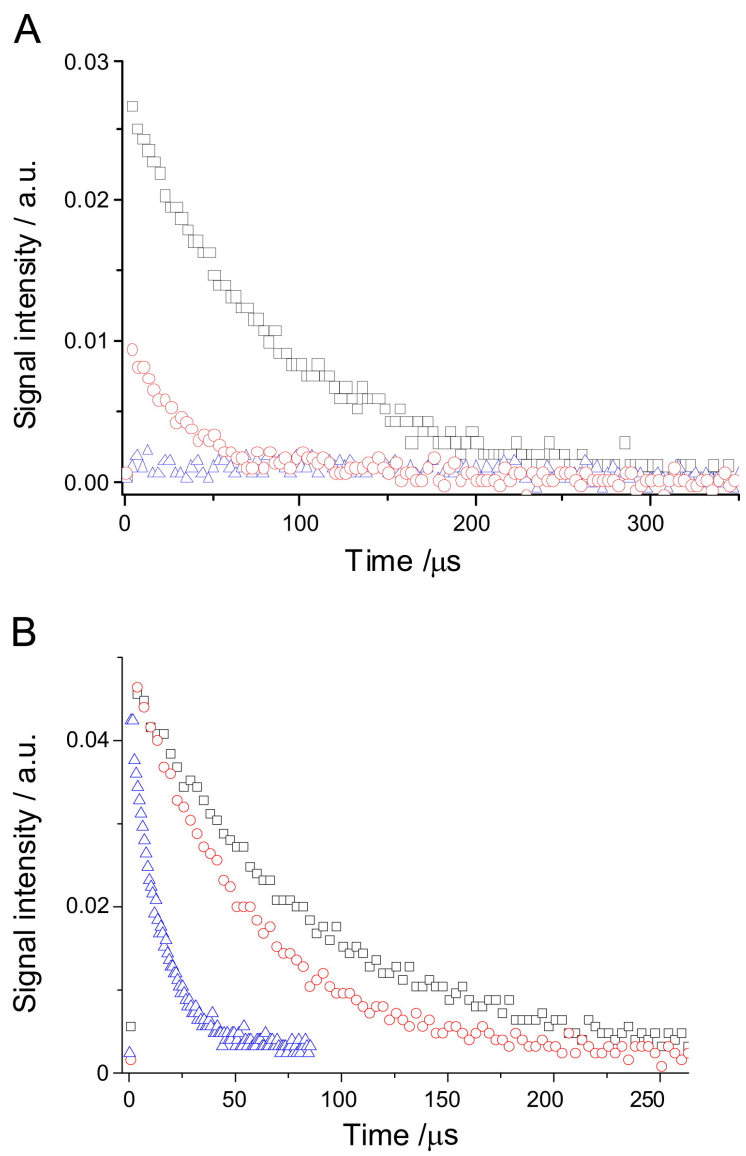

Figure 6.3: Decay of ${ }^{1} \mathrm{O}_{2}$ at $1270 \mathrm{~nm}$ in aerated $A C N$ solution of (A) BP, (B) PN with $0 \mathrm{mM}$ TEMP (black), $5 \mathrm{mM}$ TEMP (red), $50 \mathrm{mM}$ TEMP (blue). Incident $355 \mathrm{~nm}$ laser energy: 3.65 $\mathrm{mJ} / \mathrm{pulse}, \mathrm{Abs} 355=0.3$.

$90 \%$ of triplet $\mathbf{P N}$ is quenched by $\mathrm{O}_{2}$ under the employed conditions. This fact explains the difference between $\mathbf{B P}$ and $\mathbf{P N}$ in the singlet oxygen formation yields upon TEMP addition.

As regards NP and CBZ, weak intensity of the LFP signals makes their triplet states to be barely detected in the presence of TEMP (see appendix C; this was attributed to scarce population of the triplet states caused by quenching of the precursor singlet excited states. To check this hypothesis, the emission signal of NP and CBZ was monitored in the presence of TEMP. The results for $\mathbf{C B Z}$ are shown in Figure 6.4A; they reveal a marked decrease of the fluorescence intensity concomitant with the growth of a new structured emission band with peaks at 400 , 420, 450 and $470 \mathrm{~nm}$. This type of long-wavelength emission has been previously observed in the presence of amines and attributed to charge transfer in the excited 
state (excited CBZ carbanion and/or exciplex formation) [116]. The $k_{q}$ determined by means of steady-state and time-resolved emission measurements were $9.1 \times 10^{8}$ $\mathrm{M}^{-1} \mathrm{~S}^{-1}$ and $6.7 \times 10^{8} \mathrm{M}^{-1} \mathrm{~s}^{-1}$, respectively. The difference between the two values suggests the contribution of static quenching, probably due to formation of a ground-state complex.
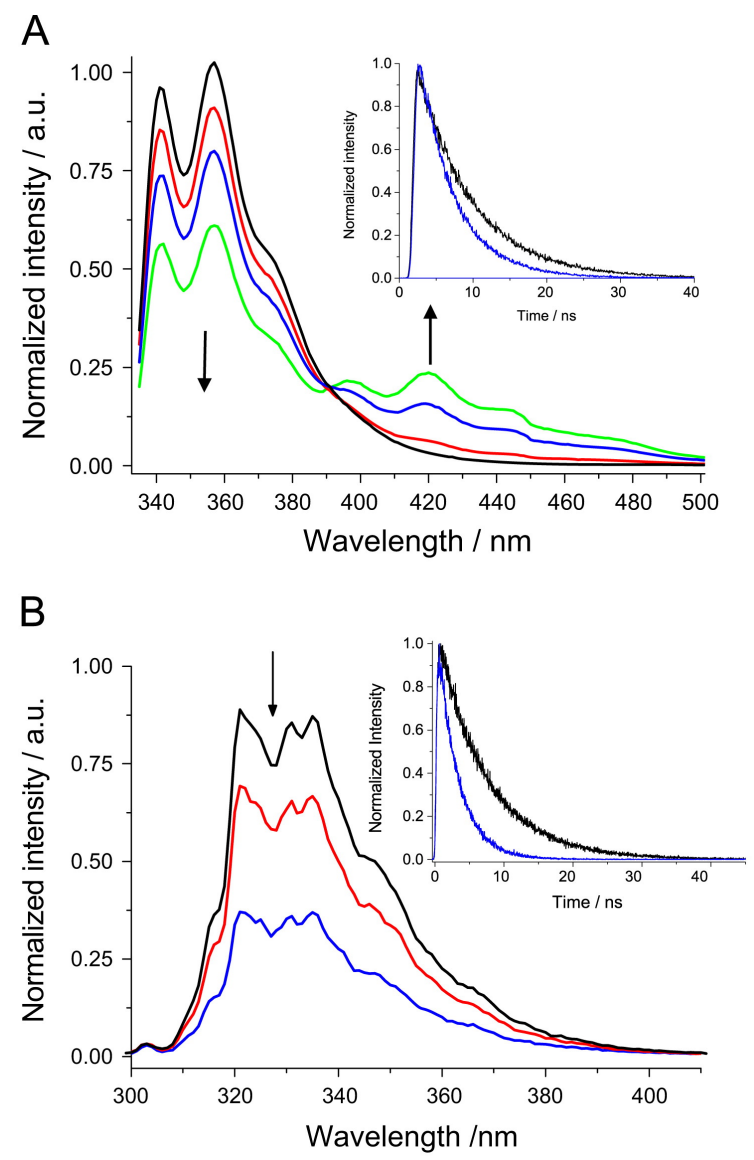

Figure 6.4: (A) Steady state fluorescence spectra of $\boldsymbol{C B Z}$ in aerated ACN solution with increasing amount of TEMP. [CBZ] $=3.5 \times 10^{-5} \mathrm{M}, \lambda_{e x}=331 \mathrm{~nm}$. [TEMP] $=0$ (black), 10 (red), 50 (blue), $100 \mathrm{mM}$ (green). Inset: Decay of $\mathbf{C B Z}$ at $341 \mathrm{~nm}$ in aerated ACN solution with $0 \mathrm{mM}$ TEMP (black), $50 \mathrm{mM}$ TEMP (blue). (B) Steady state fluorescence spectra of $\mathbf{N P}$ in aerated ACN solution with increasing amount of TEMP. $[N P]=2.3 \times 10^{-6} M, \lambda_{e x}=278 \mathrm{~nm}$. [TEMP] 0 (black), 10 (red), $50 \mathrm{mM}$ (blue). Inset: Decay of $\mathbf{N P}$ at $320 \mathrm{~nm}$ in aerated ACN solution with 0 mM TEMP (black), $50 \mathrm{mM}$ of TEMP (blue).

Likewise, the singlet excited state of NP was quenched by TEMP (Figure $6.4 \mathrm{~B})$; the rate constant obtained from steady state fluorescence $\left(k_{q}=1.9 \times 10^{9}\right.$ $\left.\mathrm{M}^{-1} \mathrm{~S}^{-1}\right)$ was similar to that resulting from time resolved fluorescence $\left(k_{q}=2.0 \times 10^{9}\right.$ $\mathrm{M}^{-1} \mathrm{~s}^{-1}$ ), indicating that NP-TEMP ground-state complex can be safely ruled out. It should be noticed that the efficient quenching of the excited photosensitizer by 
TEMP and the reduced ${ }^{1} \mathrm{O}_{2}$ production are not reflected in the EPR measurements of Table 6.1. Overall, the results related to excited state quenching by TEMP suggest the possibility of an alternative electron transfer reaction pathway for the oxidation of TEMP that produces a detectable TEMPO signal from TEMP, not involving singlet oxygen.

\subsubsection{Electron transfer oxidation of TEMP to TEMPO}

Photoinduced electron transfer (PET) is a feasible reaction between ketone or aromatic hydrocarbon photosensitizers and amines [1, 107-109]. Being a secondary amine, TEMP $\left(E_{o x}=1.0 \mathrm{~V}\right.$ vs SCE)[117] could be oxidized by PET if the process is thermodynamically allowed. According to Rehm-Weller [3], this requirement is fulfilled for all the investigated photosensitizers. Indeed $\Delta \mathrm{G}$ for electron transfer is in all cases negative, being of ca. $-10,-70,-30$ and $-70 \mathrm{~kJ} \mathrm{~mol}^{-1}$ for $\mathbf{P N}, \mathbf{B P}$, NP and CBZ, respectively. To actually prove that an electron transfer reaction can contribute to the production of the TEMPO radical, TEMP was oxidized by tris(4-bromophenyl)aminium hexachloroantimonate (also named BAHA or magic blue), a known one-electron oxidizing agent $\left(E_{r e d}=1.17 \mathrm{~V}\right.$ vs SCE) [118]. Addition of BAHA to a solution of TEMP in acetonitrile led to the bleaching of the initial blue color, which turned pale brown. The resulting solution was analyzed by EPR, and an enhanced TEMPO signal was observed under aerobic conditions. The mechanistic scheme explaining these results is outlined in Figure 6.5. Generation of the radical cation $\mathrm{TEMP}^{+}{ }^{\bullet}$ is followed by deprotonation and reaction of the resulting neutral radical with molecular oxygen, finally leading to the TEMPO radical [119-121].

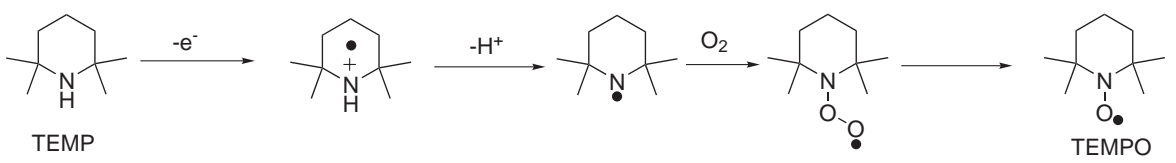

Figure 6.5: Proposed mechanism for the electron tranfer oxidation of TEMP to TEMPO in the presence of molecular oxygen.

\subsubsection{The case of rose Bengal, an archetypal ${ }^{1} \mathrm{O}_{2}$ photosen- sitizer}

The methodology was applied to rose Bengal (RB), a ${ }^{1} \mathrm{O}_{2}$ photosensitizer widely used in cellular experiments. Steady-state fluorescence showed an almost unaltered emission of RB singlet excited state in the presence of $100 \mathrm{mM}$ TEMP (Figure 6.6A). This result is in accordance with time-resolved measurements, which allowed determining a very low quenching rate constant of ca. $10^{7} \mathrm{M}^{-1} \mathrm{~s}^{-1}$ (Figure 6.6A, inset). Likewise, the triplet excited state of $\mathbf{R B}$ was not affected by the presence of the secondary amine (Figure 6.6B). Thus, from these data one can anticipate that the $\mathbf{R B}$ singlet oxygen quantum yield obtained by the TEMPO/EPR method should correlate well with that reported in the literature $\left(\Phi_{\Delta}=0.54\right)[122]$. 

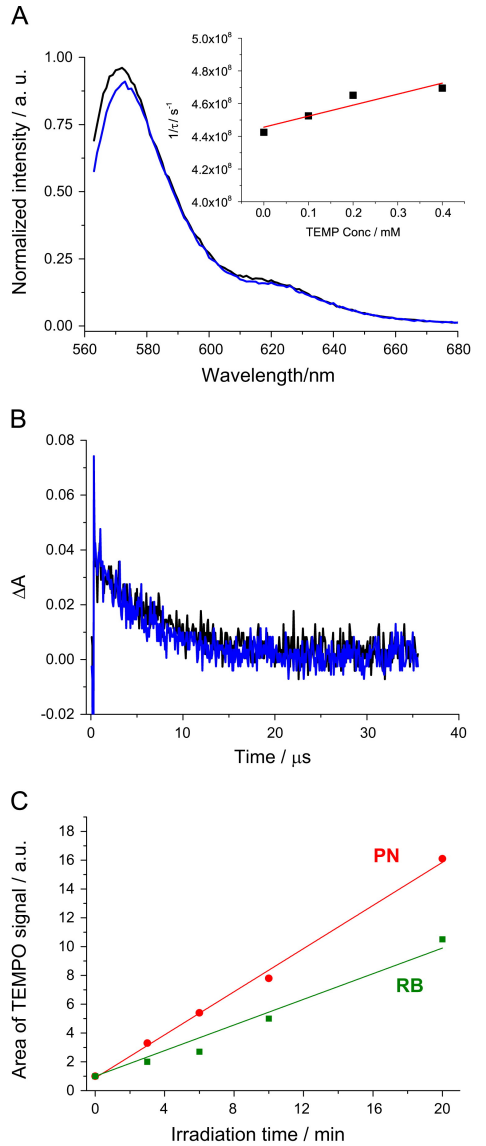

Figure 6.6: (A) Emission of an aerated ACN solution of $\boldsymbol{R B}$ alone (black) or in the presence of $100 \mathrm{mM}$ TEMP (blue). $[R B]=4 \times 10^{-6} \mathrm{M}, \lambda_{e x}=560 \mathrm{~nm}$. Inset: Stern-Volmer plot obtained from time-resolved measurements of $\mathbf{R B}$ in the presence of increasing amounts of TEMP $\left(\lambda_{e x}=\right.$ $\left.560 \mathrm{~nm}, \lambda_{e m}=573 \mathrm{~nm}\right)$. (B) $T-T$ absorption decays monitored at $620 \mathrm{~nm}\left(\lambda_{\text {ex }}=532 \mathrm{~nm}\right)$ of argon-bubbled ACN solution of $\boldsymbol{R B}\left(3.3 \times 10^{-5} \mathrm{M}\right)$ alone (black) or in the presence of $100 \mathrm{mM}$ TEMP (blue). (C) Area of TEMPO signal in EPR as a function of irradiation time at $280 \mathrm{~nm}$, $A_{280}=0.4$.

This was confirmed by performing the EPR experiment using $\mathbf{P N}$ as standard, which led to a very reasonable value of 0.56 (Figure $6.6 \mathrm{C}$ ). 


\subsection{Conclusion}

Detection and quantification of singlet oxygen by means of the TEMPO/EPR method is a useful and widely employed technique. This method however may be misleading when the excited photosensitizer is capable to react with TEMP, acting as an electron donor. In this case, generation of the TEMP ${ }^{+}$radical cation, followed by deprotonation and reaction with molecular oxygen, gives rise to a EPR detectable TEMPO signal that is not associated with singlet oxygen production. The possibility of such an electron transfer interference can be anticipated by means of simple thermodynamic calculations based on redox potentials and excited state energies. In addition, this source of artifacts can be safely ruled out when no quenching of the photosensitizer singlet and triplet excited states by TEMP is observed in fluorescence and laser flash photolysis experiments, respectively. Thus the application of such relatively simple techniques provides knowledge that is essential for an appropriate and error-free application of the TEMPO/EPR method of singlet oxygen detection in chemical, biological and medical studies.

\subsection{Experimental part}

In this section the specific experimental procedure for this chapter are described. General experimental procedures, like UV-Vis absorption spectra or emissions, are described in detail at the General experimental chapter 7 .

\subsubsection{Chemicals}

2,2,6,6-Tetramethyl-1-piperidine (TEMP), tris(4-bromophenyl)aminium hexachloroantimonate (BAHA), phenalenone (PN), benzophenone (BP), naphthalene (NP), carbazole $(\mathbf{C B Z})$, rose Bengal $(\mathbf{R B})$ and acetonitrile $(\mathrm{ACN})$ were from Sigma-Aldrich. TEMP was freshly distilled at $152^{\circ} \mathrm{C}$ before use.

\subsubsection{Steady state fluorescence quenching}

Quenching of CBZ and NP fluorescence intensity by TEMP upon excitation at 331 and $278 \mathrm{~nm}$, respectively, was performed by adding increasing amounts of TEMP to the solution. The following equation was used to determine $K_{S V}$, the Stern-Volmer quenching constant:

$$
\frac{F_{0}}{F}=1+K_{S V}[Q]
$$

$F_{0}$ and $F$ are the fluorescence intensities in the absence and presence of the quencher $\mathrm{Q}$, respectively; $[Q]$ is the quencher concentration $(\mathrm{M}), K_{S V}\left(\mathrm{M}^{-1}\right)$ the Stern-Volmer constant. The bimolecular quenching rate constant $k_{q}\left(M^{-1} s^{-1}\right)$ was obtained dividing $K_{S V}$ by the fluorescence lifetime. 


\subsubsection{Fluorescence lifetimes}

Fluorescence decays were measured in air-equilibrated solutions with a timecorrelated single photon counting apparatus (IBH 5000F) equipped with a TBX picosecond photon detection module. A NanoLED pulsed excitation source at 331 and $278 \mathrm{~nm}$ was used and the emission was collected at right angle at 341 or 320 $\mathrm{nm}$ using a long pass cutoff filter at $305 \mathrm{~nm}$. Fluorescence decay profiles were fitted using a monoexponential function of the decay analysis software DAS6 provided by the manufacturer with deconvolution of the instrumental response function.

\subsubsection{Singlet oxygen time-resolved near infrared (TRNIR) emission measurements}

All measurements were made at room temperature in $1 \mathrm{~cm}$ pathway quartz cuvettes. The absorbance of the samples was 0.30 at the laser wavelength. The singlet oxygen quantum yield $\left(\Phi_{\Delta}\right)$ was determined using phenalenone in acetonitrile $\left(\phi_{\Delta \text { (standard })}=0.95\right)[34]$ as reference. Singlet oxygen formation quantum yield was calculated from the slope of linear plots representing signal intensity at zero time versus laser pulse energy according to the following equation:

$$
\phi_{\Delta(\text { sample })}=\frac{I_{\text {sample }}}{I_{\text {standard }}} \times \phi_{\Delta(\text { standard })}
$$

where $I_{\text {sample }}$ is the emission intensity for the sample, $I_{\text {standard }}$ is the emission intensity for the standard and $\phi_{\Delta \text { (standard) }}$ is the standard quantum yield of singlet oxygen formation.

\subsubsection{EPR trapping measurements}

The EPR signal of the free radical TEMPO $\left(\mathrm{g}=2.0060, \mathrm{a}_{N}=17.3 \mathrm{G}\right)$ generated by reaction of singlet oxygen with TEMP was recorded [123]. The measurements were performed in a Wildman Suprasil/aqueous quartz ware flat cell (volume of $150 \mu L, 60 \mathrm{~mm}$ of length) with a Bruker EMX 10/12 EPR spectrometer, using the following parameters: microwave power, $20 \mathrm{~mW}$; modulation amplitude, 1.0 G; and modulation frequency, $100 \mathrm{kHz}$. Aerated ACN solutions of $50 \mathrm{mM}$ TEMP containing a photosensitizer, with an absorbance of 0.4 at $280 \mathrm{~nm}$, were irradiated using the light produced by a Microbeam system (model L-201), including a 150 W xenon lamp coupled with a monochromator (model 101); EPR spectra were recorded at different irradiation times. The singlet oxygen quantum yield $\left(\Phi_{\Delta}\right)$ was determined using phenalenone in acetonitrile $\left(\phi_{\Delta}(\right.$ standard $\left.\left.)=0.95\right)[34]\right)$ as reference. Singlet oxygen formation was calculated from the slope of the plots of signal area versus irradiation time according to the following equation:

$$
\phi_{\Delta(\text { sample })}=\frac{X_{\text {sample }}}{X_{\text {standard }}} \times \phi_{\Delta(\text { standard })}
$$

where $X_{\text {sample }}$ is the coefficient of linear fit for the sample, $X_{\text {standard }}$ is the coefficient of linear fit for the reference and $\phi_{\Delta(\text { standard })}$ is the quantum yield of sin- 
glet oxygen formation of the reference. In the case of tris(4-bromophenyl)aminium hexachloroantimonate (BAHA) oxidation, EPR spectra of aerated ACN solutions of $50 \mathrm{mM}$ TEMP were recorded before and after addition of 0.1 BAHA equivalents.

\subsubsection{Photoinduced electron transfer}

According to Rehm-Weller[3] the free energy change $\Delta G$ for electron transfer is expressed by:

$$
\Delta G=E_{o x}-E_{r e d}-E^{*}+C
$$

where $E_{o x}$ is the oxidation potential of the donor, $E_{r e d}$ the reduction potential of the ground state acceptor, $E^{*}$ the energy of the acceptor excited state and $C$ is a coulombic term accounting for the electrostatic attraction of the produced ions. Neglecting the $\mathrm{C}$ term, $\Delta G$ was calculated using the following values for the potentials: $E_{o x}(\mathrm{TEMP})=1.0 \mathrm{~V}$ and $E_{\text {red }}=-1.2,-1.3,-2.6$ and $-1.8 \mathrm{~V}$ vs SCE for PN [124], BP[102], NP [125] and CBZ [112], respectively. In the case of PN [113] and $\mathbf{B P}$ [102], the lowest triplet excited state energy was considered for $E^{*}$ with values of 220 and $292 \mathrm{~kJ} \mathrm{~mol}^{-1}$, respectively, whereas this parameter was associated with the singlet manifold for NP [125] and CBZ [23], using values of 377 and $344 \mathrm{~kJ} \mathrm{~mol}^{-1}$, respectively. 


\section{Chapter 7}

\section{General experimental procedures}

In this chapter, experimental procedures and standard equipment used in the investigation chapters are described:

\subsection{Photoreactors}

Irradiations were performed by means of a multilamp photoreactor equipped with lamps with a maximal output at ca. $300 \mathrm{~nm}$ (Hitachi, F15T8/BL). In the case of monochromatic irradiation, a Microbeam system (model L-201), including a $150 \mathrm{~W}$ Xenon lamp coupled with a monochromator (model 101), was used.

\subsection{UV-Vis absorption spectroscopy}

Absorbances of the samples were measured with a double beam Varian UV-VIS model Cary 300 Scan spectrophotometer, using $1 \mathrm{~cm}$ pathway quartz cuvettes.

\subsection{Fluorescence and phosphorescence emissions}

The steady-state fluorescence experiments were carried out on a Photon Technology International (PTI) LPS-220B spectrofluorometer. Fluorescence quantum yield measurements were performed with aerated methanol, acetonitrile and PBS solutions; the absorbance was adjusted to ca. 0.1 at the excitation wavelength , and carprofen was used as standard $\left(\Phi_{F}=0.068\right.$ in acetonitrile)[23]. All measurements were recorded using $1 \mathrm{~cm}$ pathway quartz cells with $4 \mathrm{~mL}$ capacity and were carried out at room temperature.

Phosphorescence spectra were obtained from a Photon Technology International (PTI, TimeMaster TM-2/2003) spectrofluorometer equipped with a pulsed 
Xe lamp. The apparatus was operated in time-resolved mode, with a delay time of $0.5 \mathrm{~ms}$. Compounds of interest were dissolved in ethanol, put in a quartz tube $(5$ $\mathrm{mm}$ of diameter) and cooled at $77 \mathrm{~K}$.

\subsection{Laser flash photolysis (LFP)}

Two laser flash photolysis systems were employed for the studies. For $355 \mathrm{~nm}$ and $266 \mathrm{~nm}$ excitation, experiments were carried out using the $3^{\text {rd }}$ or $4^{\text {th }}$ harmonic of a Quantel pulsed Nd:YAG spectrum laser system instrument. The single pulses were $c a .10 \mathrm{~ns}$ duration, and the energy was $c a .15 \mathrm{~mJ} /$ pulse. A pulsed Excimer Laser Systems with $\mathrm{Xe} / \mathrm{HCl}$ mixture was used for excitation at $308 \mathrm{~nm}$. The single pulses were $17 \mathrm{~ns}$ duration, and the energy was less than $100 \mathrm{~mJ} /$ pulse.

For both excitation systems, a Xenon lamp was employed as the detecting light source. The laser flash photolysis apparatus consisted of the pulsed laser, the Xe lamp, a monochromator, and a photomultiplier (PMT) system made up of side-on PMT, PMT housing, and a PMT power supply. The output signal from the Tektronix oscilloscope was transferred to a personal computer for study. All transient spectra were recorded using $1 \times 1 \mathrm{~cm}^{2}$ quartz cells with $4 \mathrm{~mL}$ capacity and solutions were bubbled for $10 \mathrm{~min}$ with $\mathrm{N}_{2}$ or $\mathrm{O}_{2}$, before acquisition. The absorbance of the samples was kept in the range $0.30-0.40$ at the laser wavelength. Stock solutions of quenchers were prepared so that it was only necessary to add microliter volumes to the sample cell to obtain appropriate concentrations of the quencher. A linear quenching plot was obtained, and the resulting rate constant was calculated from the slope of the Stern-Volmer plot

$$
k_{o b s}=k_{0}+k_{q}[Q]
$$

where $k_{0}$ is the triplet decay rate constant in the absence of quencher, $k_{q}$ is the triplet decay rate constant in the presence of the quencher, and $[Q]$ is the quencher concentration in $\mathrm{mol} \cdot \mathrm{L}^{-1}$.

\subsection{Singlet oxygen measurements}

\subsubsection{ITQ (UPV-CSIC) system, used in chapter 3}

The singlet oxygen phosphorescence decay traces after the laser pulse were registered at $1270 \mathrm{~nm}$ employing a Peltier-cooled $\left(-62.8^{\circ} \mathrm{C}\right)$ Hamamatsu NIR detector operating at $588 \mathrm{~V}$, coupled to a computer-controlled grating monochromator. A pulsed Nd:YAG L52137 V LOTIS TII was used at the excitation wavelength of 266 $\mathrm{nm}$. The single pulses were ca. $10 \mathrm{~ns}$ duration, and the energy was lower than 10 $\mathrm{mJ} / \mathrm{pulse}$. 


\subsubsection{ISOF-CNR system, used in chapter 6}

The pulse of a Nd:YAG laser, operating at $355 \mathrm{~nm}$ or $266 \mathrm{~nm}$ (20 ns fwhm), was used for excitation of the samples dissolved in air-equilibrated acetonitrile. A preamplified (low impedance) Ge-photodiode (Applied Detector Corp., Model $403 \mathrm{HS}$, time resolution $300 \mathrm{~ns}$ ), cooled at $77 \mathrm{~K}$ and equipped with a $5 \mathrm{~mm}$ thick $\mathrm{AR}$ coated silicon metal filter with wavelength pass $>1.1 \mu \mathrm{m}$ and an interference filter at $1.27 \mu \mathrm{m}$, was used to measure emission of singlet oxygen at $1270 \mathrm{~nm}$ in right angle geometry. The photodiode output current was fed into a digital oscilloscope.

\subsection{NMR and HRMS spectroscopic characteriza- tion}

${ }^{1} \mathrm{H}$ NMR and ${ }^{13} \mathrm{C}$ NMR were recorded on a $300 \mathrm{MHz}$ spectrometer (U300, Varian) operating in the Fourier transform mode. The chemical shifts are reported in ppm (parts per million), using TMS as the internal reference. HRMS was performed on a Waters ACQUITY XevoQToF spectrometer (Waters Corp.) connected to the UPLC system via an electrospray ionization (ESI) interface. The ESI source was operated in positive ionization mode using leucine-enkephalin as the lock mass $([\mathrm{M}+\mathrm{H}]+$ ion $m / z 556.2771)$. 


\section{Chapter 8}

\section{Summaries}

\subsection{Summary}

Photosensitizing effects of xenobiotics are of increasing concern in public health since modern lifestyle often associates sunlight exposure with the presence of chemical substances in the skin. An important number of chemicals like perfumes, sunscreen components, or therapeutic agents have been reported as photosensitizers. In this context, a considerable effort has been made to design a model system for photosafety assessment. Indeed, screening for phototoxicity is necessary at the early phase of drug discovery process, even before introducing drugs and chemicals into clinical therapy, to prevent undesired photoreactions in humans. In the case of new pharmaceuticals, their phototoxic potential has to be tested when they absorb in the regions corresponding to the solar spectrum, that is, for wavelengths $>290 \mathrm{~nm}$. So, there is an obvious need for a screening strategy based on in vitro experiments. The goal of the present thesis was the photochemical study of different photoactive drugs to investigate the key molecular aspects responsible for their photosensitivity side effects.

In a first stage, rosuvastatin was considered in chapter 3 as representative compound of the statin family. This lipid-lowering drug, also known as "superstatin", contains a 2-vinylbiphenyl-like moiety and has been previously described to decompose under solar irradiation, yielding stable dihydrophenanthrene analogues. During photophysical characterization of rosuvastatin, only a long-lived transient at ca. $550 \mathrm{~nm}$ was observed and assigned to the primary photocyclization intermediate. Thus, the absence of detectable triplet-triplet absorption and the low yield of fluorescence ruled out the role of the parent drug as an efficient sensitizer. In this context, the attention was placed on the rosuvastatin main photoproduct (ppRSV). Indeed, the photobehavior of this dihydrophenanthrene-like compound presented the essential components needed for an efficient biomolecule photosensitizer i.e. (i) a high intersystem crossing quantum yield $\left(\Phi_{I S C}=0.8\right)$, (ii) a triplet excited state energy of ca. $67 \mathrm{kcal} \mathrm{mol}^{-1}$, and (iii) a quantum yield of 
singlet oxygen formation $\left(\Phi_{\Delta}\right)$ of 0.3 . Furthermore, laser flash photolysis studies revealed a triplet-triplet energy transfer from the triplet excited state of ppRSV to thymidine, leading to the formation of cyclobutane thymidine dimers, an important type of DNA lesion. Finally, tryptophan was used as a probe to investigate the Type I and/or Type II character of ppRSV-mediated oxidation. In this way, both an electron transfer process giving rise to the tryptophanyl radical and a singlet oxygen mediated oxidation were observed. On the basis of the obtained results, rosuvastatin, through its major photoproduct ppRSV, should be considered as a potential sensitizer.

Then, itraconazole (ITZ), a broad-spectrum antifungal agent, was chosen as main character of chapter 4 . Its photochemical properties were investigated in connection with its reported skin photosensitivity disorders. Steady state photolysis, fluorescence and phosphorescence experiments were performed to understand ITZ photoreactivity in biological media. The drug is unstable under UVB irradiation, suffering a primary dehalogenation of the 2,4-dichlorophenyl moiety that occurs mainly at the ortho-position. In poorly H-donating solvents, as acetonitrile, the major photoproduct arises from intramolecular attack of the initially generated aryl radical to the triazole ring. In addition, reduced compounds resulting from homolytic cleavage of the $\mathrm{C}-\mathrm{Cl}$ bond in ortho or para positions and subsequent $\mathrm{H}$ abstraction from the medium are obtained to a lesser extent. In good H-donating solvents, such as ethanol, the main photoproducts are formed by reductive dehalogenation. Furthermore, irradiation of a model dyad containing a tryptophan unit and the reactive 2,4-dichlorophenyl moiety of itraconazole leads to formation of a new covalent link between these two substructures revealing that homolysis of the $\mathrm{C}-\mathrm{Cl}$ bond of ITZ can result in alkylation of reactive amino acid residues of proteins, leading to formation of covalent photoadducts. Therefore, it has been established that the key process in the photosensitization by itraconazole is cleavage of the carbon-halogen bond, which leads to aryl radicals and chlorine atoms. These highly reactive species might be responsible for extensive free radical-mediated biological damage, including lipid peroxidation or photobinding to proteins.

In chapter 5, photobehavior of imatinib (IMT) was addressed. This is a promising tyrosine kinase inhibitor used in the treatment of some types of human cancer, which constitutes a successful example of rational drug design based on the optimization of the chemical structure to reach an improved pharmacological activity. Cutaneous reactions, such as increased photosensitivity or pseudoporphyria, are among the most common nonhematological IMT side effects; however, the molecular bases of these clinical observations have not been unveiled yet. Thus, to gain insight into the IMT photosensitizing properties, its photobehavior was studied together with that of its potentially photoactive anilino-pyrimidine and pyridyl-pyrimidine fragments. In this context, steady-state and time resolved fluorescence, as well as laser flash photolysis experiments were run, and the DNA photosensitization potential was investigated by means of single strand breaks detection using agarose gel electrophoresis. The obtained results revealed that 
the drug itself and its anilino-pyrimidine fragment are not DNA-photosensitizers. By contrast, the pyridyl-pyrimidine substructure displayed a marked photogenotoxic potential, which was associated with the generation of a long-lived triplet excited state. Interestingly, this reactive species was efficiently quenched by benzanilide, another molecular fragment of IMT. Clearly, integration of the photoactive pyridyl-pyrimidine moiety in a more complex structure strongly modifies its photobehavior, which in this case is fortunate as it leads to an improved toxicological profile. Thus, on the bases of the experimental results, direct in vivo photosensitization by IMT seems unlikely. Instead, the reported photosensitivity disorders could be related to indirect processes, such as the previously suggested impairment of melanogenesis or the accumulation of endogenous porphyrins.

Finally, a possible source of errors in the TEMPO/EPR method for singlet oxygen detection was analyzed. For many biological and biomedical studies, it is essential to detect the production of ${ }^{1} \mathrm{O}_{2}$ and to quantify its production yield. Among the available methods, detection of the characteristic $1270 \mathrm{~nm}$ phosphorescence of singlet oxygen by time-resolved near infrared (TRNIR) emission constitutes the most direct and unambiguous approach. An alternative indirect method is electron paramagnetic resonance (EPR) in combination with trapping. This is based on the detection of the TEMPO free radical formed after oxidation of TEMP $(2,2,6,6-$ tetramethylpiperidine) by singlet oxygen. Although the TEMPO/EPR method has been largely employed, it can produce misleading data. This was demonstrated by the present study, where the quantum yields of singlet oxygen formation obtained by TRNIR emission and by the TEMPO/EPR method were compared for a set of well-known photosensitizers. The results revealed that the TEMPO/EPR method leads to significant overestimation of singlet oxygen yield when the singlet or triplet excited state of the photosensitizers were efficiently quenched by TEMP, acting as electron donor. In such case, generation of the $\mathrm{TEMP}^{+} \bullet$ radical cation, followed by deprotonation and reaction with molecular oxygen gives rise to a EPR detectable TEMPO signal that is not associated with singlet oxygen production. This knowledge is essential for an appropriate and error-free application of the TEMPO/EPR method in chemical, biological and medical studies. 


\subsection{Resumen}

Los efectos fotosensibilizantes de los xenobióticos son de creciente interés para la salud pública ya que el estilo de vida moderna a menudo asocia la exposición solar con la presencia de sustancias químicas en la piel. Un número importante de productos químicos como perfumes, protectores solares, o agentes terapéuticos han sido reconocidos como fotosensibilizadores. En este contexto, se ha realizado un considerable esfuerzo para diseñar un sistema modelo para evaluar la seguridad frente la luz.De hecho, el control de la fototoxicidad es necesario en las primeras fases del proceso de desarrollo de fármacos, incluso antes de la introducción de medicamentos y productos químicos en la terapia clínica, para prevenir fotorreacciones no deseadas en humanos. En el caso de nuevos productos farmacéuticos, su potencial fototóxico tiene que ser probado cuando éstos absorben en las regiones correspondientes del espectro solar, es decir, para longitudes de onda>290 nm. Por lo tanto, existe la evidente necesidad de una estrategia de control basada en experimentos in vitro.El objetivo de la presente tesis fue el estudio fotoquímico de diferentes fármacos fotoactivos para investigar los mecanismos moleculares clave responsables de sus efectos secundarios de fotosensibilidad.

En una primera etapa, en el capítulo 3 , la rosuvastatina fue elegida como compuesto representativo de la familia de las estatinas. Este fármaco reductor de lípidos, también conocido como "superestatina", contiene un grupo 2-vinilbifenilo y, como se ha descrito previamente se descompone bajo irradiación solar, dando análogos de dihidrofenantreno estables. Durante la caracterización fotofísica de la rosuvastatina, se observó sólo una especie transitoria de larga duración a aproximadamente $550 \mathrm{~nm}$ y fue asignada al intermedio primario de la fotociclación. Por lo tanto, la ausencia de una absorción triplete-triplete y el bajo rendimiento de fluorescencia descartan el papel del fármaco original como sensibilizador eficiente. En este contexto, se centró la atención en el fotoproducto principal de la rosuvastatina (ppRSV). De hecho, las propiedades de este compuesto dihidrofenantreno presentaron los rasgos esenciales necesarios para ser un fotosensibilizador eficiente, es decir, (i) un alto rendimiento cuántico de cruce intersistemas $\left(\Phi_{I S C}=0.8\right)$, (ii) una energía de estado excitado triplete de aproximadamente $67 \mathrm{kcal} \mathrm{mol}^{-1}$, y (iii) un rendimiento cuántico de formación de oxígeno singlete $\left(\Phi_{\Delta}\right)$ de 0.3. Además, los estudios de fotólisis de destello láser revelaron una transferencia de energía triplete-triplete desde el estado excitado triplete de ppRSV a la timidina, lo que lleva a la formación de dímeros ciclobutánicos de timidina, un tipo importante de lesión del ADN. Por último, el triptófano se utilizó como sonda para investigar la oxidación de Tipo I o de Tipo II mediada por ppRSV. De esta manera, se observó un proceso de transferencia de electrones que da lugar al radical triptofanilo y una oxidación mediada por oxígeno singlete. Sobre la base de los resultados obtenidos, la rosuvastatina, a través de su fotoproducto mayoritario $\mathbf{p p R S V}$, debe ser considerada como un potencial sensibilizador.

Posteriormente, el itraconazol (ITZ), un agente antifúngico de amplio espectro, fue elegido como protagonista principal del capítulo 4. Sus propiedades foto- 
químicas fueron investigadas en relación con los efectos adversos como la fotosensibilidad. Se realizaron estudios de fotólisis en estado estacionario, experimentos de fluorescencia y fosforescencia para comprender la fotorreactividad del ITZ en medios biológicos. El fármaco es inestable bajo irradiación UVB, dando lugar a una deshalogenación en la parte de 2,4-diclorofenilo principalmente en la posición orto. En disolventes como el acetonitrilo, el principal fotoproducto surge del ataque intramolecular del radical arilo, generado inicialmente, al anillo de triazol. Además, los compuestos resultantes de la ruptura homolítica del enlace $\mathrm{C}-\mathrm{Cl}$ en posiciones orto o para y posterior abstracción de hidrógeno desde el medio se obtienen en menor cantidad. En disolventes capaces de ceder $\mathrm{H}$ más facilmente, tales como el etanol, los principales fotoproductos se forman por deshalogenación reductiva. Además, la irradiación de una diada modelo, que contiene una unidad de triptófano y el radical reactivo , 2,4-diclorofenilo del itraconazol, se obtiene la formación de un nuevo enlace covalente entre estas dos subestructuras. Esto revela que la homólisis del enlace C-Cl del ITZ puede resultar en la alquilación de residuos de aminoácidos reactivos de las proteínas, que posteriormente conducirá a la formación de fotoaductos covalentes. Por lo tanto, se ha establecido que el proceso clave en la fotosensibilización del itraconazol es la ruptura del enlace carbono-halógeno, que produce radicales arilo y átomos de cloro. Estas especies altamente reactivas pueden ser responsables de importantes daños biológicos mediados por radicales libres, incluyendo la peroxidación lipídica o fotounión a las proteínas.

En el capítulo 5, se aborda el comportamiento fotoquímico del imatinib (IMT). Este es un inhibidor de la tirosina quinasa utilizado en el tratamiento de algunos tipos de cáncer humano. Este fármaco constituye un claro ejemplo de diseño racional basado en la optimización de la estructura química para alcanzar una mejor actividad farmacológica. Las reacciones cutáneas, como el aumento de fotosensibilidad o pseudoporfiria, son algunos de los efectos secundarios no hematológicos más comunes del IMT; sin embargo, las bases moleculares de estas indicaciones clínicas no se conocen todavía. Por lo tanto, para comprender mejor las propiedades fotosensibilizantes del IMT, se estudió su comportamiento fotoquímico junto con el de sus fragmentos potencialmente fotoactivos: anilino-pirimidina y piridilo-pirimidina. En este contexto, se llevaron a cabo experimentos de fluorescencia en estado estacionario y en tiempo resuelto, así como de fotólisis de destello láser, y se investigó el potencial de fotosensibilización hacia el ADN por medio de la detección de roturas de cadena utilizando la electroforesis en gel de agarosa. Los resultados obtenidos revelaron que el fármaco en sí y su fragmento anilino-pirimidina no son fotosensibilizadores de ADN. Por el contrario, la subestructura piridilo-pirimidina exhibe un marcado potencial fotogenotóxico, que se asoció con la presencia de un estado excitado triplete de larga duración. Curiosamente, esta especie reactiva se desactiva de manera eficiente por benzanilida, otro fragmento molecular del IMT. Claramente, la integración de la fracción fotoactiva piridilo-pirimidina en una estructura más compleja modifica fuertemente su comportamiento fotoquímico, que en este caso resulta afortunado, lo que conduce a un perfil toxicológico mejorado. Por lo tanto, sobre la base de los resultados experimentales, una fotosensibilización directa in 
vivo por el IMT parece poco probable. En cambio, los trastornos de fotosensibilidad reportados podrían estar relacionados con los procesos indirectos, tales como la reducción de la melanogénesis, sugerida anteriormente, o la acumulación de porfirinas endógenas.

Por último, se analizó la restricción del método TEMPO / EPR para la detección del oxígeno de singlete. Para muchos estudios biológicos y biomédicos, es esencial detectar la producción de ${ }^{1} \mathrm{O}_{2}$ y cuantificar su rendimiento cuántico. Entre los métodos disponibles, la detección de la fosforescencia característica del oxígeno singlete a $1270 \mathrm{~nm}$ por emisión resuelta en el tiempo en el rango del infrarrojo cercano (TRNIR), constituye el enfoque más directo y sin ambigüedades. Un método indirecto alternativo es la resonancia paramagnética electrónica (EPR) en combinación con una sonda. Esto se basa en la detección del radical libre TEMPO formado después de la oxidación del TEMP (2,2,6,6-tetrametilpiperidina) por el oxígeno singlete. Aunque el método TEMPO / EPR se ha utilizado frecuentemente, puede dar lugar a artefactos. Esto fue demostrado en el presente estudio, donde se compararon los rendimientos cuánticos de formación de oxígeno singlete obtenidos por emisión TRNIR y por el método TEMPO/EPR para un conjunto de fotosensibilizadores. Los resultados revelaron que el método TEMPO/EPR conduce a una sobrestimación significativa del rendimiento de oxígeno singlete cuando el estado excitado singlete o triplete de los fotosensibilizadores es desactivado de manera eficiente por TEMP, que actúa como donador de electrones. En tal caso, la generación de catión radical $\mathrm{TEMP}^{+} \bullet$, seguida por desprotonación y reacción con oxígeno molecular, da lugar a una señal detectable por EPR que no está asociada con la producción de oxígeno singlete. Este conocimiento es esencial para una aplicación adecuada y sin errores del método EPR/TEMPO en química, biológica y medicina. 


\subsection{Resum}

Els efectes fotosensibilitzants dels xenobiòtics són de creixent interès per a la salut pública ja que l'estil de vida moderna sovint s'associa l'exposició solar amb la presència de substàncies químiques sobre la pell. Un nombre important de productes químics com perfums, protectors solars, o agents terapèutics han sigut reconeguts com fotosensibilitzadors. En aquest context, s'han fet una sèrie d'esforços per a dissenyar un sistema model per a avaluar la seguretat front la llum. De fet, el control de la fototoxicitat és necessari en les primeres fases del procés de desenvolupament de fàrmacs, fins i tot abans de la introducció de medicaments i productes químics en la teràpia clínica, per a prevenir fotoreaccions no desitjades en humans. En el cas de nous productes farmacèutics, el seu potencial fototòxic ha de ser provat quan aquests absorbeixen en les regions corresponents de l'espectre solar, és a dir, per a longituds d'ona> $290 \mathrm{~nm}$. Per tant, existeix l'evident necessitat d'una estratègia de control basada en experiments in vitro.L'objectiu de la present tesi va ser l'estudi fotoquímic de diferents fàrmacs fotoactius per a investigar els mecanismes moleculars clau responsables dels seus efectes secundaris de fotosensibilitat.

En una primera etapa, en el capítol 3, la rosuvastatina va ser triada com a compost representatiu de la família de les estatines. Aquest fàrmac reductor de lípids, també conegut com "superestatina", conté una resta 2-vinilbifenilo i, com s'ha descrit prèviament es descompon sota irradiació solar, donant anàlegs de dihidrofenantrè estables. Durant la caracterització fotofísica de la rosuvastatina, es va observar només una espècie transitòria de llarga durada a aproximadament 550 nm i es va assignar a l'intermedi primari de la fotociclació. Per tant, l'absència d'una absorció triplet-triplet i el baix rendiment de fluorescència descarten el paper del fàrmac original com sensibilizator eficient. En aquest context, es va enfocar l'atenció en el fotoproducte principal de la rosuvastatina (ppRSV). De fet, les propietats d'aquest compost dihidrofenantré van presentar els components essencials necessaris per a ser un fotosensibilizator eficient, és a dir, (i) un alt rendiment quàntic de creuament intersistems $\left(\Phi_{I S C}=0.8\right)$, (ii) una energia d'estat excitat triplet d'aprox $67 \mathrm{~mol}^{-1} \mathrm{kcal}$, i (iii) un rendiment quàntic de formació d'oxigen molecular de singlet $\left(\Phi_{\Delta}\right)$ de 0.3 . A més, els estudis de fotòlisi de flaix làser van revelar una transferència d'energia triplet-triplet des de l'estat excitat triplet de ppRSV al de la timidina, la qual cosa porta a la formació de dímers ciclobutànics de timidina, un tipus important de lesió de l'ADN. Finalment, el triptòfan es va utilitzar com sonda per a investigar l'oxidació de tipus I o de tipus II intervinguda per ppRSV. D'aquesta manera, es va observar un procés de transferència d'electrons que dóna lloc al radical triptofanil i una oxidació intervinguda per oxigen singlet. Sobre la base dels resultats obtinguts, la rosuvastatina, a través del seu major fotoproducteppRSV, ha de ser considerada com un potencial sensibilitzator.

Posteriorment, l'itraconazol (ITZ), un agent antifúngi d'ampli espectre, va ser triat com a protagonista principal del capítol 4. Les seues propietats fotoquímiques van ser investigades a causa de les molèsties relacionades amb la fotosensibilitat. 
Fotòlisi en estat estacionari, experiments de fluorescència i fosforescència es van realitzar per a comprendre la fotoreactivitat del ITZ en mitjans biològics. El fàrmac és inestable sota irradiació UVB, donant lloc a una dehsalogenació primària en la fracció 2,4-diclorofenil principalment en la posició orto. En acetonitril, el principal fotoproducte sorgeix de l'atac intramolecular del radical arilo, generat inicialment, a l'anell de triazol. A més, els compostos resultants de la ruptura homolítica de l'enllaç C-Cl en posicions orto o para i posterior abstracció d'hidrogen des del mitjà s'obtenen en menor quantitat. En dissolvents que cedeixen fàcilment $\mathrm{H}$, tals com l'etanol, els principals fotoproducte es formen per deshalogenació reductiva. A més, la irradiació d'una diada model, que conté una unitat de triptòfan i el radical 2,4-diclorofenil reactiu del itraconazol, es conclou amb la formació d'un nou enllaç covalent entre aquestes dues subestructures. Açò revela que l' homólisi de l'enllaç C-Cl de ITZ pot acabar amb l'alquilació de residus d'aminoàcids reactius de les proteïnes, que posteriorment condueixen a la formació de fotoaductes covalents. Per tant, s'ha establit que el procés clau en la fotosensibilització de l'itraconazol és la ruptura de l'enllac carboni-halogen, que produeix radicals arilo i àtoms de clor. Aquestes espècies altament reactives poden ser responsables d'importants danys biològics intervinguts per radicals lliures, incloent la peroxidació lipídica o fotounió a les proteïnes.

En el capítol 5, es parla del comportament fotoquímic de l'imatinib (IMT). Este és un inhibidor de la tirosina quinasa utilitzat en el tractament d'alguns tipus de càncer humà. Aquest fàrmac constitueix un clar exemple de disseny racional de fàrmacs basat en l'optimització de l'estructura química per a aconseguir una millor activitat farmacològica. Les reaccions cutànies, com l'augment de fotosensibilitat o pseudoporfíria, són alguns dels efectes secundaris no hematològics més comuns de l'IMT; no obstant açò, les bases moleculars d'aquestes indicacions clíniques no es coneixen encara. Per tant, per a comprendre millor les propietats fotosensibilitzants de l'IMT, es va estudiar el seu comportament fotoquímic juntament amb els de els seus fragments potencialment fotoactius: anilino-pirimidina i piridilo-pirimidina. En aquest context, es van dur a terme experiments de fluorescència en estat estacionari i en temps resolt, així com de fotòlisi de flaix làser, i es va investigar el potencial de fotosensibilització cap a l'ADN per mitjà de la detecció de trencaments de cadena utilitzant l'electroforesi en gel de agarosa. Els resultats obtinguts van revelar que el fàrmac en sí i el seu fragment anilino-pirimidina no són fotosensibilitzadors d'ADN. En cas contrari, la subestructura piridilo-pirimidina presenta un marcat potencial fotogenotòxic, que es va associar amb la presència d'un estat excitat triplet de llarga durada. Curiosament, aquesta espècie reactiva es desactiva de manera eficient per benzanilida, un altre fragment molecular de l'IMT. Clarament, la integració de la fracció fotoactiva piridilo-pirimidina en una estructura més complexa modifica fortament el seu comportament fotoquímic, que en aquest cas resulta afortunata, ja que condueix a un perfil toxicològic millorat. Per tant, sobre la base dels resultats experimentals, per l'IMT sembla poc probable una fotosensibilització directa in vivo. En canvi, els trastorns de fotosensibilitat reportats podrien estar relacionats amb els processos indirectes, tals com la reducció 
de la melanogènesi, suggerida anteriorment, o l'acumulació de porfirines endògenes.

Finalment, es va analitzar una errada present en el mètode TEMPO / EPR per a la detecció d'oxigen de singlet. Per a molts estudis biològics i biomèdics, és essencial detectar la producció de ${ }^{1} \mathrm{O}_{2}$ i quantificar el seu rendiment quàntic. Entre els mètodes disponibles, la detecció de la fosforescència característica d'oxigen singlet a $1270 \mathrm{~nm}$, emissió resolta en el temps en l'infraroig proper (TRNIR), constitueix l'enfocament més directe i sense ambigüitats. Un mètode indirecte alternatiu és la ressonància paramagnètica electrònica (EPR) en combinació amb "trapping". Açò es basa en la detecció del radical lliure TEMPO format després de l'oxidació del TEMP (2,2,6,6-tetrametilpiperidina) per l'oxigen singlet. Encara que el mètode TEMPO / EPR s'ha utilitzat freqüentment, pot produir resultats ambigus. Açò va ser demostrat pel present estudi, on es van comparar els rendiments quàntics de formació d'oxigen singlet obtinguts per emissió TRNIR i pel mètode TEMPO/EPR per a un conjunt de fotosensibilizadors acreditats. Els resultats van revelar que el mètode TEMPO/EPR condueix a una sobrestimació significativa del rendiment d'oxigen singlet quan l'estat excitat singlet o triplet dels fotosensibilitzadors és desactivat de manera eficient per TEMP, que actua com a donador d'electrons. En tal cas, la generació de catió radical $\mathrm{TEMP}^{+} \bullet$, seguit per desprotonació i reacció amb oxigen molecular, dóna lloc a una senyal detectable per EPR que no està associada amb la producció d'oxigen singlet. Aquest coneixement és essencial per a una aplicació adequada i sense errors en el mètode EPR/TEMPO en química, biologia $\mathrm{i}$ en estudis mèdics. 


\section{Chapter 9}

\section{General conclusions}

In the present thesis, the photosensitization capability of three drugs has been evaluated. Photochemical, photophysical and photobiological studies have allowed determining the main molecular mechanisms responsible for the sensitizing processes.

One of the main conclusions is that instability of the drug under irradiation does not avoid a possible phototoxicity. On the contrary, the results obtained for rosuvastatin and itraconazole have shown that photodegradation of the drug could provide photosensitization through two different paths:

- A rearrangement of chemical bonds could give rise to a photoproduct that is the real responsible for the adverse effects ascribed to parent drug. This has been established in the chapter 3 where ppRSV, the photoproduct of rosuvastatin, is proposed to be the real sensitizer

- The photoreaction intermediates could be the reactive species. This possibility has been illustrated for itraconazole in chapter 4, In this case, the aryl radical formed through UVB-mediated photodehalogenation could be the responsible for tryptophan alkylation. This has been studied by means of a model dyad composed by the itraconazole aryl moiety and tryptophan.

An interesting case relies on the study of the tyrosine kinase inhibitor imatinib in chapter 5, which reveals that photosensitizing potential is neither predictable by the absorption in the UV region nor by the phototoxic potential of its substructures. Indeed, the two chromophores of the drug (ie. anilino-pyrimidine and pyridyl-pyrimidine) exhibit triplet excited states, which could be in the origin of biomolecule sensitization. In particular, the pyridyl-pyrimidine fragment has been shown to photoinduce DNA single strand breaks, whereas imatinib does not. This has been associated with the interference of a third moiety that promotes an internal deactivation. 
Finally, the limitation of the TEMPO/EPR methodology has been established. This technique is widely used in biochemical studies in order to determine the production of singlet oxygen. It has been demonstrated in chapter 6 that particular attention has to be held on ${ }^{1} \mathrm{O}_{2}$ sensitizers able to oxidize the TEMP molecule by a photoinduced electron transfer. In this case, formation of TEMPO does not result from its reaction with ${ }^{1} \mathrm{O}_{2}$ but from a reaction of molecular oxygen with TEMP radical cation.

Taking these results altogether, the following flow diagram can be proposed in order to evaluate the photosensitizing potential of chemicals: 


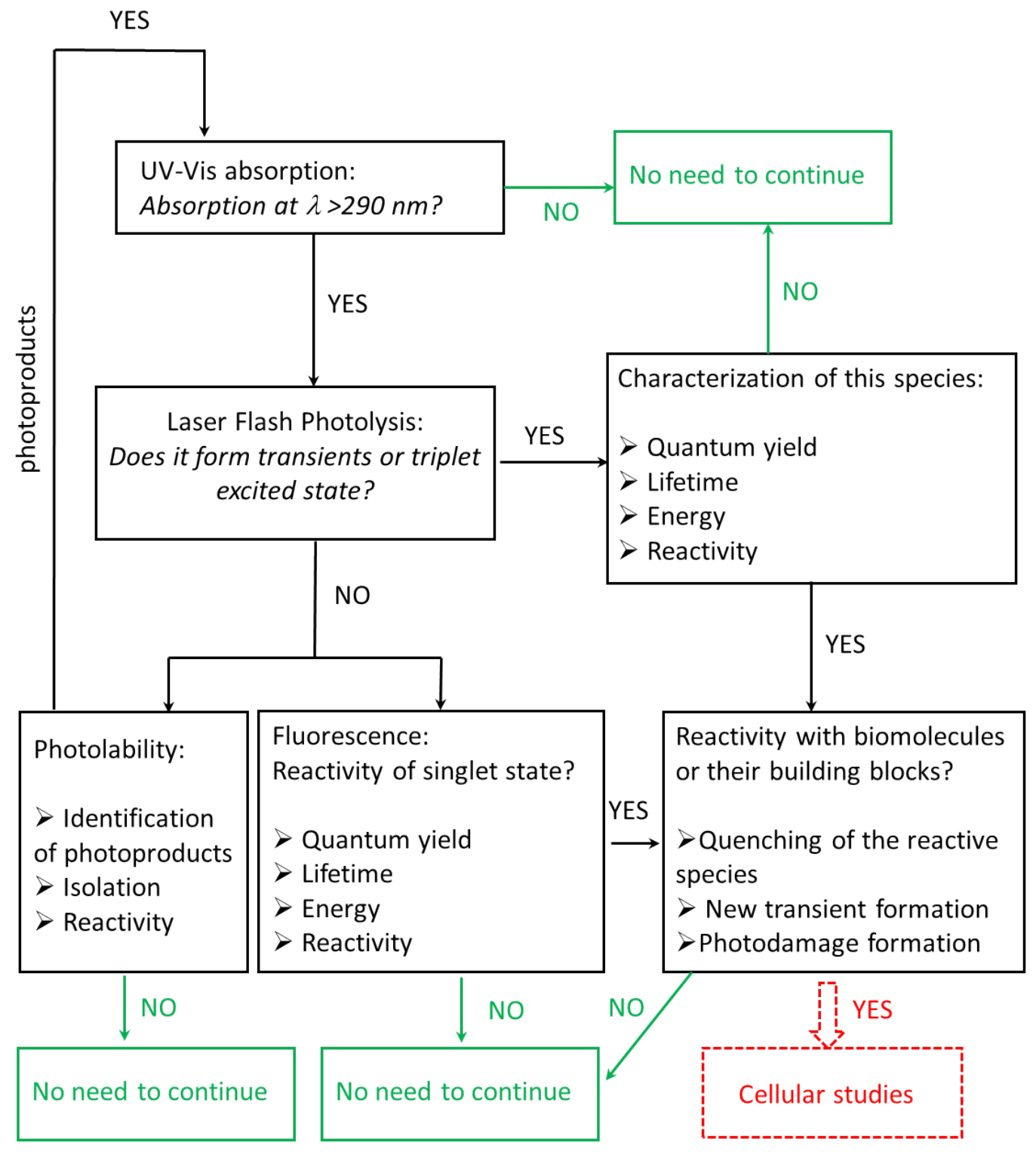




\section{Appendix A}

\section{Appendix of chapter 4}

\section{A.1 Itraconazole}

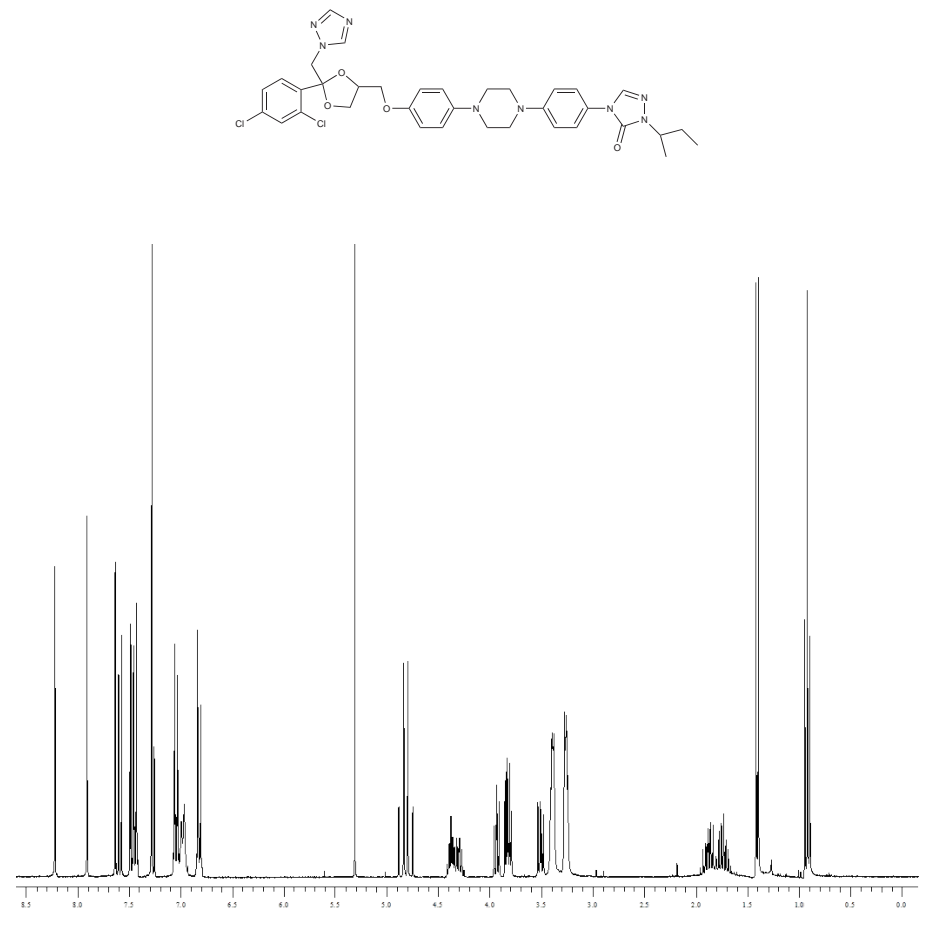

${ }^{1} \mathrm{H}-\mathrm{NMR}\left(300 \mathrm{MHz}, \mathrm{CDCl}_{3}\right) \delta 8,22(\mathrm{~s}, 1 \mathrm{H}), 7,91(\mathrm{~s}, 1 \mathrm{H})$ 7,64 (s,1H) 7,59 (d, J= $8,4 \mathrm{~Hz}, 1 \mathrm{H}), 7,50(\mathrm{~d}, \mathrm{~J}=2,1 \mathrm{~Hz}, 1 \mathrm{H}) 7,44$ (d, J=9,0 Hz, 2H), 7,27 (dd, J= 8,4 ; 2,1 $\mathrm{Hz}, 1 \mathrm{H}), 7,04(\mathrm{~d}, \mathrm{~J}=9,0 \mathrm{~Hz}, 2 \mathrm{H}), 6,97(\mathrm{~d}, \mathrm{~J}=8,7 \mathrm{~Hz}, 2 \mathrm{H}), 6,82(\mathrm{~d}, \mathrm{~J}=8,7 \mathrm{~Hz}, 2 \mathrm{H})$ $4,85(\mathrm{~d}, \mathrm{~J}=14,7 \mathrm{1H}), 4,76(\mathrm{~d}, \mathrm{~J}=14,71 \mathrm{H}), 4,38(\mathrm{~m}, 1 \mathrm{H}) 4,31(\mathrm{~m}, 1 \mathrm{H}), 3,93(\mathrm{dd}, \mathrm{J}=$ $8,4 ; 6,7 \mathrm{~Hz}, 1 \mathrm{H}), 3,84(\mathrm{~m}, 1 \mathrm{H}), 3,80(\mathrm{~m}, 1 \mathrm{H}) 3,51$ (dd, J=9,7 ; 6,3 Hz, $1 \mathrm{H}) 3,40$ 


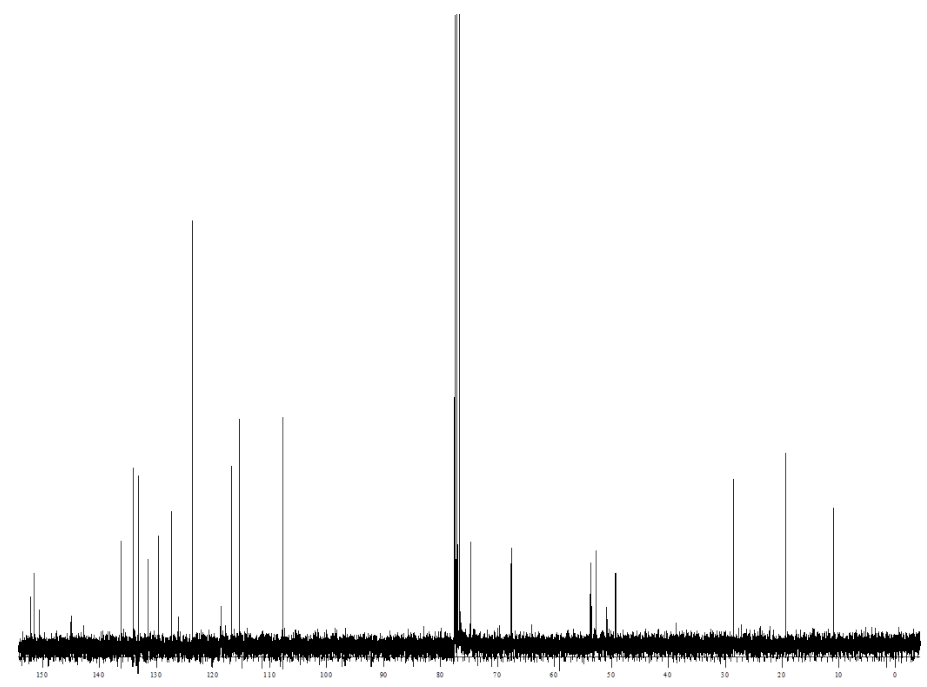

$(\mathrm{m}, 2 \mathrm{H}), 3,27(\mathrm{~m}, 2 \mathrm{H}), 1,89(\mathrm{~m}, 1 \mathrm{H}), 1,73(\mathrm{~m}, 1 \mathrm{H}) 1,40(\mathrm{~d}, \mathrm{~J}=6,7 \mathrm{~Hz}, 1 \mathrm{H}), 0,92(\mathrm{t}$, $\mathrm{J}=7,4 \mathrm{~Hz}, 1 \mathrm{H}) .{ }^{13} \mathrm{C}-\mathrm{NMR}\left(75 \mathrm{MHz}, \mathrm{CDCl}_{3}\right) \delta 152,0(\mathrm{C}) 151,4(\mathrm{C}+\mathrm{CH}), 150,5(\mathrm{C})$ $144,9(\mathrm{C}+\mathrm{CH}) 136,1(\mathrm{C}) 134,1(\mathrm{C}) 133,9(\mathrm{CH}) 133,1(\mathrm{CH}) 131,5(\mathrm{CH}) 129,6(\mathrm{CH})$ $127,3(\mathrm{CH}), 126,0(\mathrm{C}), 123,6(2 \mathrm{XCH}) 118,6(2 \mathrm{XCH}) 116,7(2 \mathrm{XCH}), 115,3(2 \mathrm{XCH})$ $107,7(\mathrm{C}) 74,7(\mathrm{CH}) 67,7(\mathrm{CH} 2)$ 67,5 (CH2) 53,6 (CH2) 52,7 (CH) 50,7 (2XCH2) 49,2 (2XCH2) 28,5 (CH2) 19,3 (CH3) 10,8 (CH3). 


\section{A.2 Photoproduct 2}
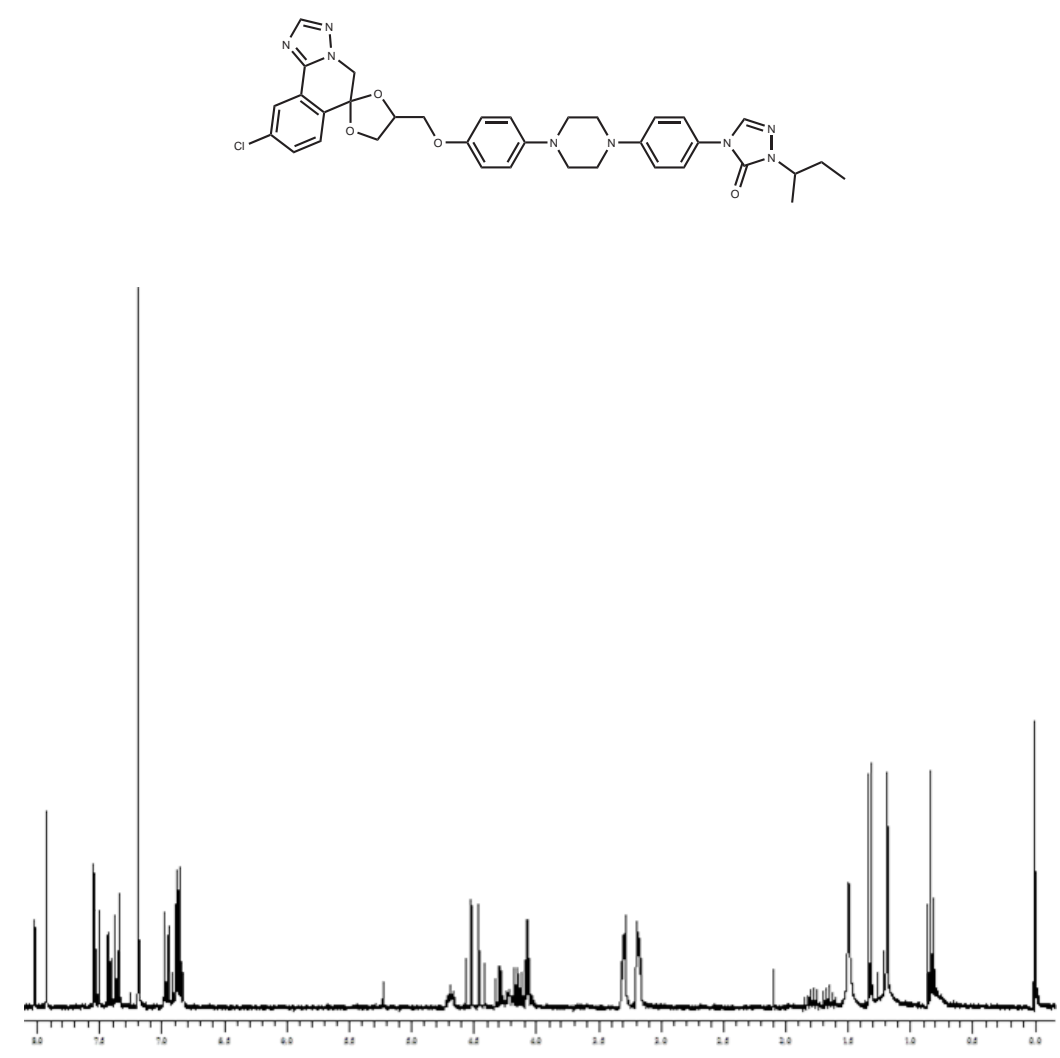

${ }^{1} \mathrm{H}-\mathrm{NMR}\left(300 \mathrm{MHz}, \mathrm{CDCl}_{3}\right) \delta 8.09(\mathrm{~d}, 1 \mathrm{H}) 8.00(\mathrm{~d}, 1 \mathrm{H}), 7.62(\mathrm{~s}, 1 \mathrm{H}), 7.59(\mathrm{~d}$, $\mathrm{J}=8.3 \mathrm{~Hz}, 1 \mathrm{H}), 7.49(\mathrm{dd}, \mathrm{J}=8.3 \mathrm{~Hz}, \mathrm{~J}=2.1 \mathrm{~Hz}, 1 \mathrm{H}), 7.43(\mathrm{~d}, \mathrm{~J}=9.0 \mathrm{~Hz}, 2 \mathrm{H})$, $7.03(\mathrm{~d}, \mathrm{~J}=9.0 \mathrm{~Hz}, 2 \mathrm{H}), 6.94\left(\mathrm{AA}^{\prime} \mathrm{BB}^{\prime}, 4 \mathrm{H}\right), 4.76(\mathrm{~m}, 1 \mathrm{H}), 4.61$ (d, J = $13.7 \mathrm{~Hz}$, $1 \mathrm{H}), 4.51(\mathrm{~d}, \mathrm{~J}=13.7 \mathrm{~Hz}, 1 \mathrm{H}), 4.37(\mathrm{dd}, \mathrm{J}=7.0 \mathrm{~Hz}, \mathrm{~J}=6.5 \mathrm{~Hz}, 1 \mathrm{H}), 4.29(\mathrm{~m}$, $1 \mathrm{H}), 4.22(\mathrm{dd}, \mathrm{J}=7.0 \mathrm{~Hz}, \mathrm{~J} '=6.5 \mathrm{~Hz}, 1 \mathrm{H}), 4.15(\mathrm{~m}, 2 \mathrm{H}), 3.37(\mathrm{~m}, 4 \mathrm{H}), 3.25(\mathrm{~m}$, $4 \mathrm{H}), 1.87(\mathrm{~m}, 1 \mathrm{H}), 1.72(\mathrm{~m}, 1 \mathrm{H}), 1.39(\mathrm{~d}, \mathrm{~J}=6.7 \mathrm{~Hz}, 3 \mathrm{H}), 0.91(\mathrm{t}, \mathrm{J}=7.4 \mathrm{~Hz}$, 3H). ${ }^{13} \mathrm{C}-\mathrm{NMR}\left(75 \mathrm{MHz}, \mathrm{CDCl}_{3}\right) \delta 152.7$ (C), $152.0(\mathrm{C}), 151.9(\mathrm{CH}), 150.5(\mathrm{C})$, $148.9(\mathrm{C}), 146.3(\mathrm{C}), 136.6(\mathrm{C}), 133.9(\mathrm{C}), 132.9(\mathrm{CH}), 130.6(\mathrm{CH}), 126.1(\mathrm{CH})$, $126.0(\mathrm{C}), 125.4(\mathrm{C}), 125.0(\mathrm{CH}), 123.6(\mathrm{CH}), 118.5(\mathrm{CH}), 116.7(\mathrm{CH}), 115.5(\mathrm{CH})$, $105.4(\mathrm{C}), 76.4(\mathrm{CH}), 67.7(\mathrm{CH} 2), 67.0(\mathrm{CH} 2), 54.0(\mathrm{CH} 2), 52.7(\mathrm{CH}), 50.6(\mathrm{CH} 2)$, 49.3 (CH2), 29.7 (CH2), 19.3 (CH3), 10.8 (CH3). HRMS (ESI ${ }^{+}$) Calculated for $\mathrm{C}_{35} \mathrm{H}_{38} \mathrm{ClN}_{8} \mathrm{O}_{4}(\mathrm{M}+\mathrm{H})^{+}$:

669.2698, Found: 669.2704. 


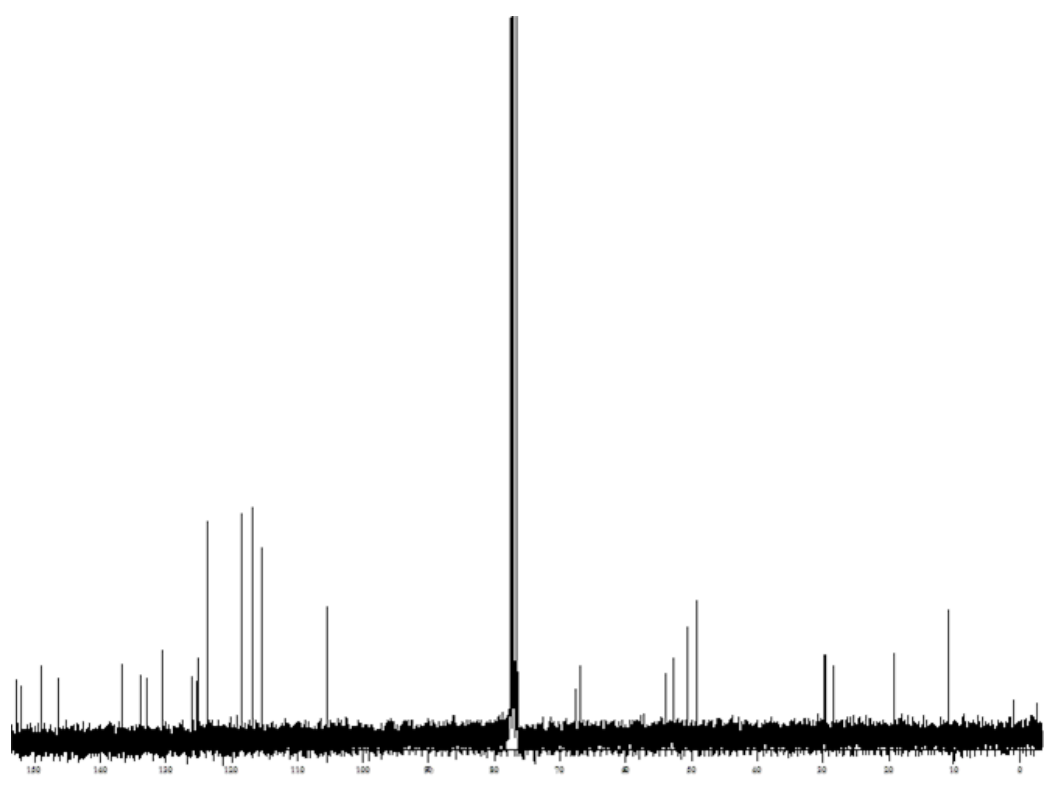

\section{A.3 Photoproduct 3}

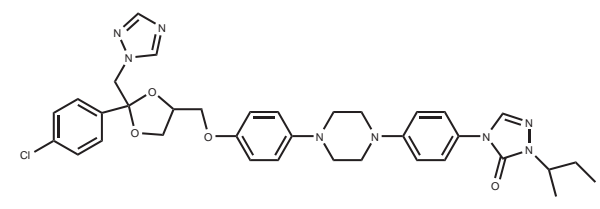

${ }^{1} \mathrm{H}-\mathrm{NMR}\left(300 \mathrm{MHz}, \mathrm{CDCl}_{3}\right) \delta 8.19(\mathrm{~s}, 1 \mathrm{H}), 7.91(\mathrm{~s}, 1 \mathrm{H}), 7.62(\mathrm{~s}, 1 \mathrm{H}), 7.47(\mathrm{~d}$, $\mathrm{J}=9.1 \mathrm{~Hz}, 2 \mathrm{H}), 7.43(\mathrm{~d}, \mathrm{~J}=9.1 \mathrm{~Hz}, 2 \mathrm{H}), 7.37(\mathrm{~d}, \mathrm{~J}=9.1 \mathrm{~Hz}, 2 \mathrm{H}), 7.02(\mathrm{~d}, \mathrm{~J}=9.1$ $\mathrm{Hz}, 2 \mathrm{H}), 6.93(\mathrm{~d}, \mathrm{~J}=9.1 \mathrm{~Hz}, 2 \mathrm{H}), 6.80(\mathrm{~d}, \mathrm{~J}=9.1 \mathrm{~Hz}, 2 \mathrm{H}), 4.50(\mathrm{~s}, 2 \mathrm{H}), 4.40-4.25$ $(\mathrm{m}, 2 \mathrm{H}), 3.89(\mathrm{dd}, \mathrm{J}=5.4 \mathrm{~Hz}, \mathrm{~J}=4.3 \mathrm{~Hz}, 1 \mathrm{H}), 3.81(\mathrm{dd}, \mathrm{J}=5.4 \mathrm{~Hz}, \mathrm{~J}=3.1 \mathrm{~Hz}$, $1 \mathrm{H}), 3.76(\mathrm{dd}, \mathrm{J}=6.2 \mathrm{~Hz}, \mathrm{~J} '=3.1 \mathrm{~Hz}, 1 \mathrm{H}), 3.47(\mathrm{dd}, \mathrm{J}=6.2 \mathrm{~Hz}, \mathrm{~J}=4.3 \mathrm{~Hz}, 1 \mathrm{H})$, $3.35(\mathrm{~m}, 4 \mathrm{H}), 3.23(\mathrm{~m}, 4 \mathrm{H}), 1.87(\mathrm{~m}, 1 \mathrm{H}), 1.71(\mathrm{~m}, 1 \mathrm{H}), 1.39(\mathrm{~d}, \mathrm{~J}=6.7 \mathrm{~Hz}, 3 \mathrm{H})$, $0.90(\mathrm{t}, \mathrm{J}=7.9 \mathrm{~Hz}, 3 \mathrm{H})$.

${ }^{13} \mathrm{C}-\mathrm{NMR}\left(75 \mathrm{MHz}, \mathrm{CDCl}_{3}\right) \delta 152.7(\mathrm{C}), 152.1(\mathrm{C}), 151.3(\mathrm{C}), 150.6(\mathrm{CH})$, $146.0(\mathrm{C}), 144.8(\mathrm{CH}), 137.4(\mathrm{C}), 135.4(\mathrm{C}), 133.9(\mathrm{CH}), 128.9(\mathrm{CH}), 127.3(\mathrm{CH})$, $125.9(\mathrm{C}), 123.6(\mathrm{CH}), 118.5(\mathrm{CH}), 116.7(\mathrm{CH}), 115.3(\mathrm{CH}), 107.8(\mathrm{C}), 74.7(\mathrm{CH})$, 67.9 (CH2), $67.4(\mathrm{CH} 2), 55.8(\mathrm{CH} 2), 52.7(\mathrm{CH}), 50.6(\mathrm{CH} 2), 49.3(\mathrm{CH} 2), 28.4$ (CH2), 19.3 (CH3), 10.8 (CH3).

HRMS (ESI ${ }^{+}$) Calculated for $\mathrm{C}_{35} \mathrm{H}_{40} \mathrm{ClN}_{8} \mathrm{O}_{4}(\mathrm{M}+\mathrm{H})^{+}$: 671.2861, Found: 671.2856 

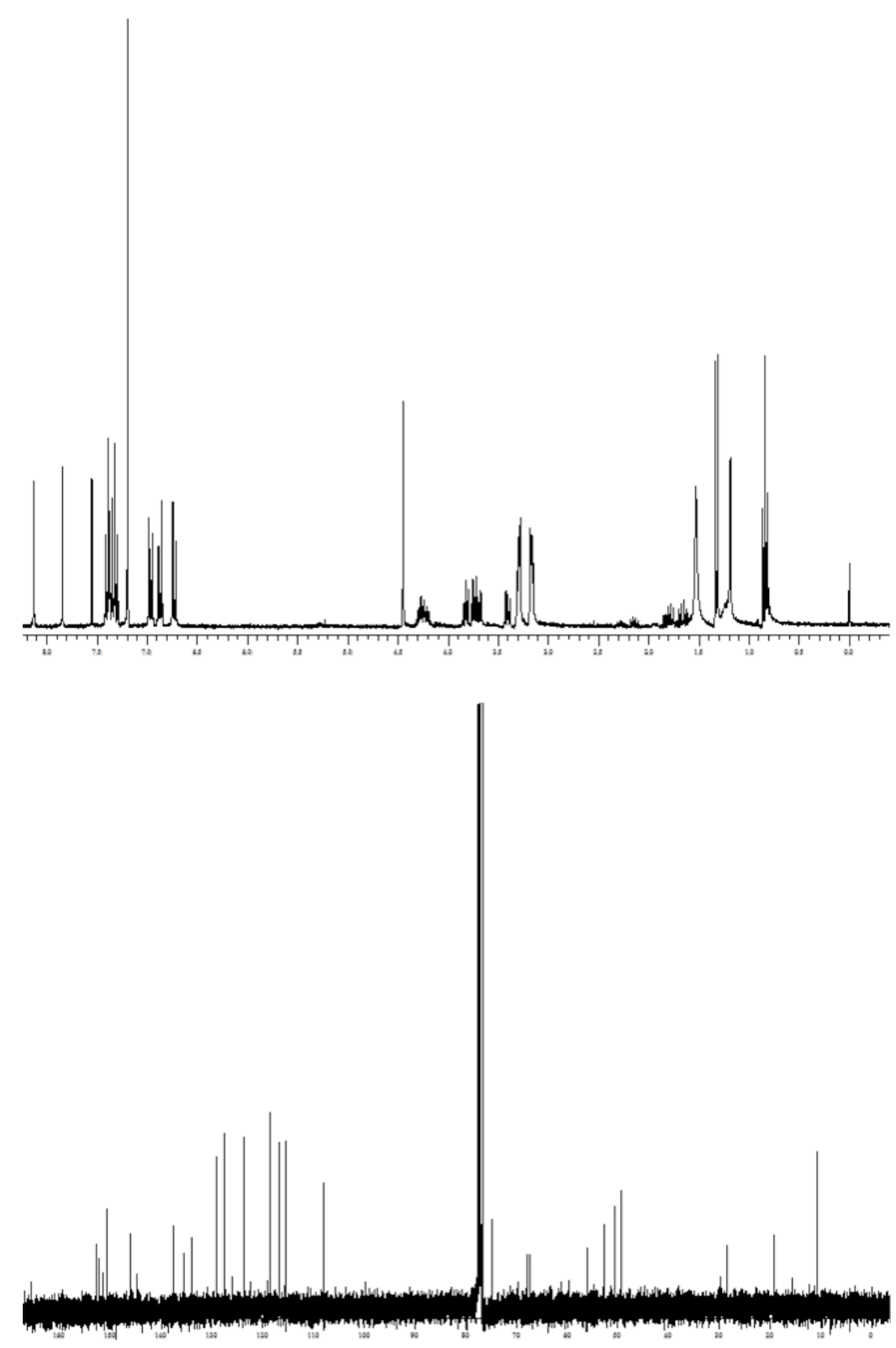

\section{A.4 Photoproduct 4}

${ }^{1} \mathrm{H}-\mathrm{NMR}\left(300 \mathrm{MHz}, \mathrm{CDCl}_{3}\right) \delta 8.24$ (br s, 1H), 7.92 (br s, 1H) ,7.66 (dd, J = $7.4 \mathrm{~Hz}, \mathrm{~J} '=1.9 \mathrm{~Hz}, 1 \mathrm{H}), 7.62(\mathrm{br} \mathrm{s}, 1 \mathrm{H}), 7.47(\mathrm{~m}, 1 \mathrm{H}), 7.43(\mathrm{~d}, \mathrm{~J}=9.1 \mathrm{~Hz}, 2 \mathrm{H})$, 7.36-7.22 (m, 2H), $7.04(\mathrm{~d}, \mathrm{~J}=9.1 \mathrm{~Hz}, 2 \mathrm{H}), 6.98(\mathrm{~d}, \mathrm{~J}=9.0 \mathrm{~Hz}, 2 \mathrm{H}), 6.81$ (d, J $=9.0 \mathrm{~Hz}, 2 \mathrm{H}), 4.90(\mathrm{~d}, \mathrm{~J}=14.7 \mathrm{~Hz}, 1 \mathrm{H}), 4.79(\mathrm{~d}, \mathrm{~J}=14.7 \mathrm{~Hz}, 1 \mathrm{H}), 4.38(\mathrm{~m}, 1 \mathrm{H})$, 


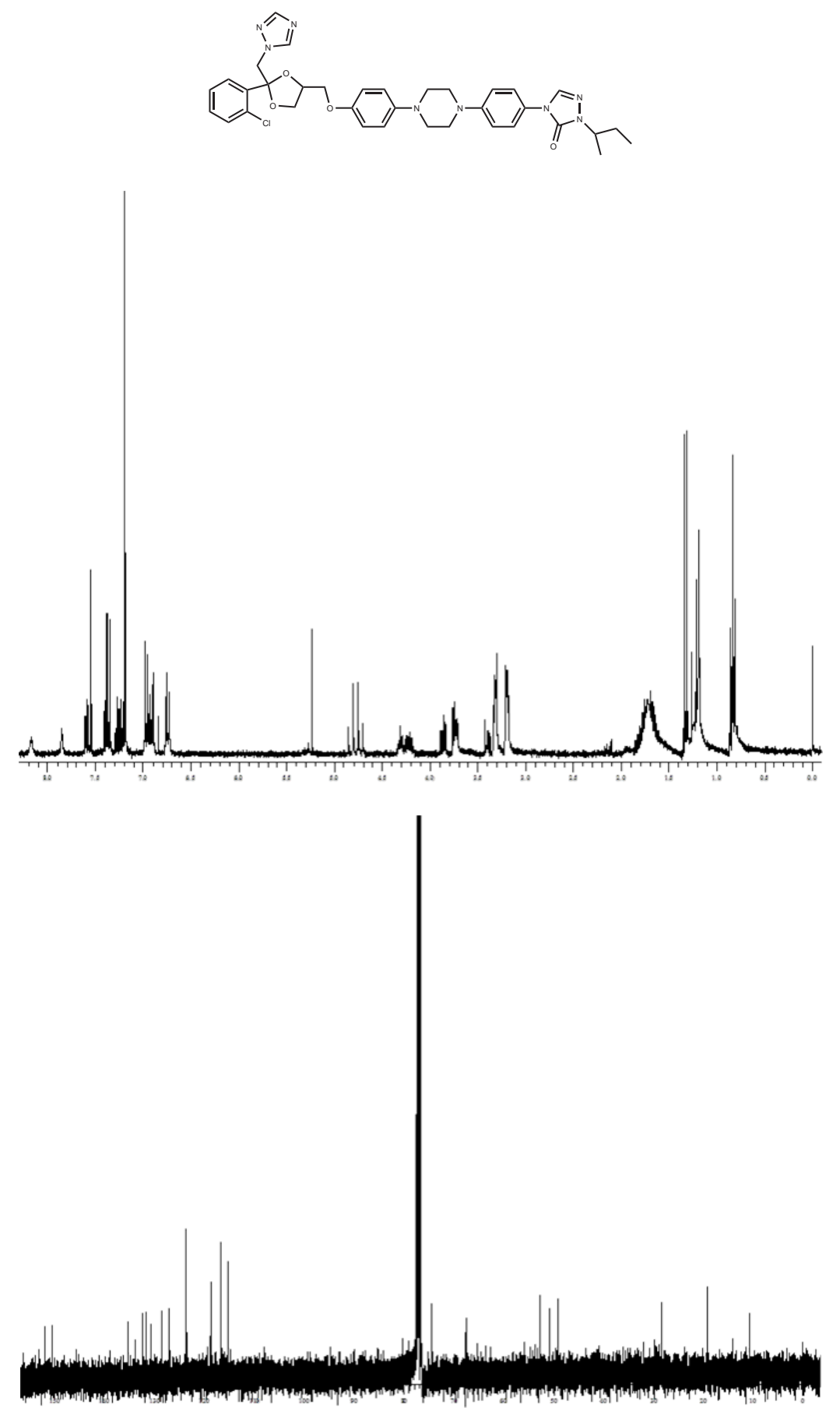


$4.29(\mathrm{~m}, 1 \mathrm{H}), 3.93(\mathrm{dd}, \mathrm{J}=8.4 \mathrm{~Hz}, \mathrm{~J} '=6.8 \mathrm{~Hz}, 1 \mathrm{H}), 3.83-3.77(\mathrm{~m}, 2 \mathrm{H}), 3.47$ (dd, $\mathrm{J}=9.6 \mathrm{~Hz}, \mathrm{~J} '=6.4 \mathrm{~Hz}, 1 \mathrm{H}), 3.39(\mathrm{~m}, 4 \mathrm{H}), 3.27(\mathrm{~m}, 4 \mathrm{H}), 1.97-1.67(\mathrm{~m}, 2 \mathrm{H}), 1.39$ $(\mathrm{d}, \mathrm{J}=7.0 \mathrm{~Hz}, 3 \mathrm{H}), 0.91(\mathrm{t}, \mathrm{J}=7.4 \mathrm{~Hz}, 3 \mathrm{H})$.

${ }^{13} \mathrm{C}-\mathrm{NMR}\left(75 \mathrm{MHz}, \mathrm{CDCl}_{3}\right) \delta 153.0(\mathrm{C}), 152.5(\mathrm{C}), 152.0(\mathrm{C}), 150.4(\mathrm{CH})$, $135.3(\mathrm{CH}), 133.9(\mathrm{CH}), 132.3(\mathrm{C}), 131.7(\mathrm{CH}), 130.8(\mathrm{CH}), 128.6(\mathrm{CH}), 127.0$ $(\mathrm{CH}), 126.1(\mathrm{C}), 123.6(\mathrm{CH}), 118.8(\mathrm{CH}), 116.8(\mathrm{CH}), 115.4(\mathrm{CH}), 107.9(\mathrm{C}), 74.5$ $(\mathrm{CH}), 67.8$ (CH2), $67.4(\mathrm{CH} 2), 53.7(\mathrm{CH} 2), 52.7(\mathrm{CH}), 50.9(\mathrm{CH} 2), 49.1$ (CH2), 28.4 (CH2), 19.3 (CH3), 10.8 (CH3).

HRMS (ESI $\left.{ }^{+}\right)$Calculated for $\mathrm{C}_{35} \mathrm{H}_{40} \mathrm{ClN}_{8} \mathrm{O}_{4}(\mathrm{M}+\mathrm{H})^{+}$:

671.2861, Found: 671.2861. 


\section{A.5 Model dyad 5}<smiles>COC(=O)C(Cc1c[nH]c2ccccc12)NC(=O)Cc1ccc(Cl)cc1Cl</smiles>

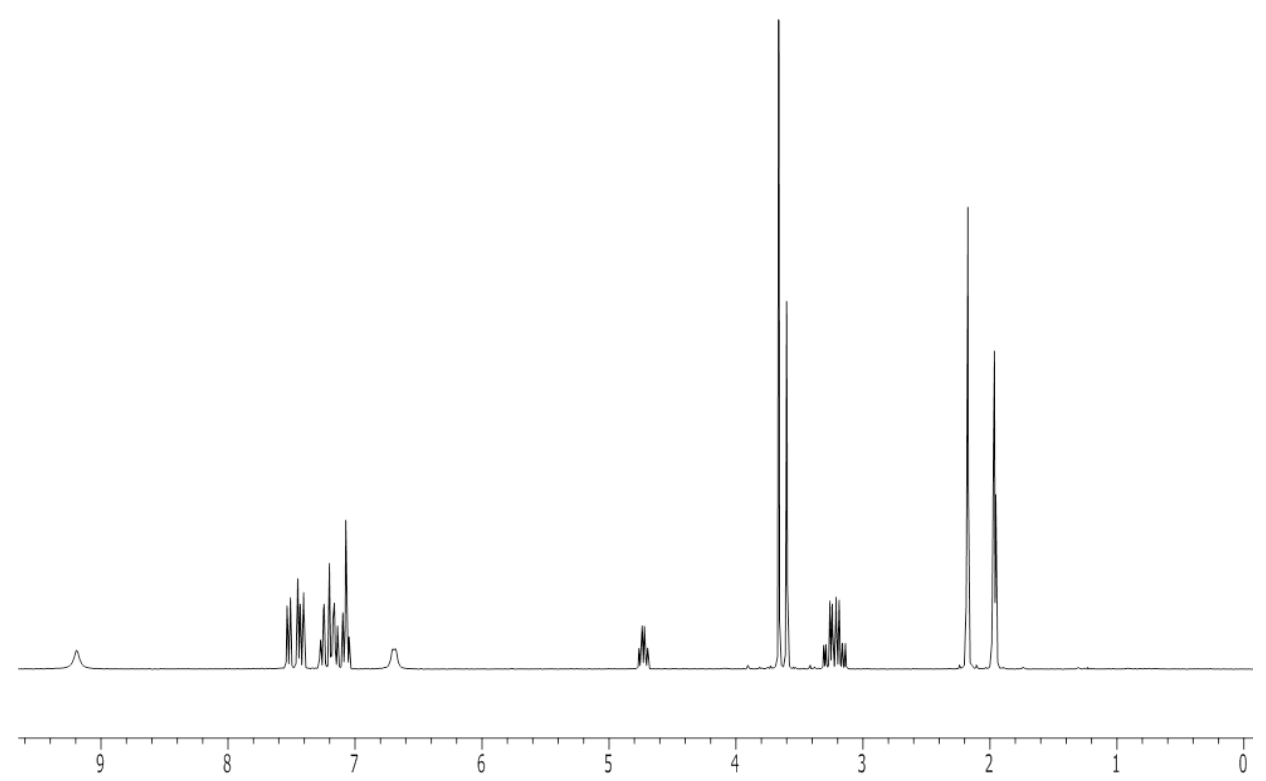

${ }^{1} \mathrm{H}-\mathrm{NMR}\left(300 \mathrm{MHz}, \mathrm{CD}_{3} \mathrm{CN}\right) \delta 9.19$ (br s, 1H) $7.52(\mathrm{~d}, \mathrm{~J}=7.9 \mathrm{~Hz}, 1 \mathrm{H}), 7.45-$ $7.40(\mathrm{~m}, 2 \mathrm{H}), 7.26-7.05(\mathrm{~m}, 5 \mathrm{H}), 6.69(\mathrm{br} \mathrm{s}, 1 \mathrm{H}) 4.73(\mathrm{~m}, 1 \mathrm{H}) 3.66(\mathrm{~s}, 3 \mathrm{H}), 3.60$ $(\mathrm{s}, 2 \mathrm{H}), 3.27\left(\mathrm{dd}, \mathrm{J}=14.7 \mathrm{~Hz}, \mathrm{~J}^{\prime}=5.4 \mathrm{~Hz}, 1 \mathrm{H}\right), 3.18(\mathrm{dd}, \mathrm{J}=14.7 \mathrm{~Hz}, \mathrm{~J}=7.2$ $\mathrm{Hz}, 1 \mathrm{H})$.

${ }^{13} \mathrm{C}-\mathrm{NMR}\left(75 \mathrm{MHz}, \mathrm{CD}_{3} \mathrm{CN}\right) \delta 171.8(\mathrm{C}), 168.5(\mathrm{C}), 136.1(\mathrm{C}), 134.6(\mathrm{C}), 132.7$ (C), $132.4(\mathrm{CH}), 132.4(\mathrm{C}), 128.5(\mathrm{CH}), 127.1(\mathrm{C}), 126.9(\mathrm{CH}), 123.4(\mathrm{CH}), 121.3$ $(\mathrm{CH}), 118.7(\mathrm{CH}), 117.9(\mathrm{CH}), 111.1(\mathrm{CH}), 109.2(\mathrm{C}), 52.9(\mathrm{CH}), 51.4(\mathrm{CH} 3), 39.1$ (CH2), 26.8 (CH2).

HRMS $\left(\mathrm{ESI}^{+}\right)$Calculated for $\mathrm{C}_{20} \mathrm{H}_{19} \mathrm{Cl}_{2} \mathrm{~N}_{2} \mathrm{O}_{3}(\mathrm{M}+\mathrm{H})^{+}$: 405.0773, Found: 405.0780. 

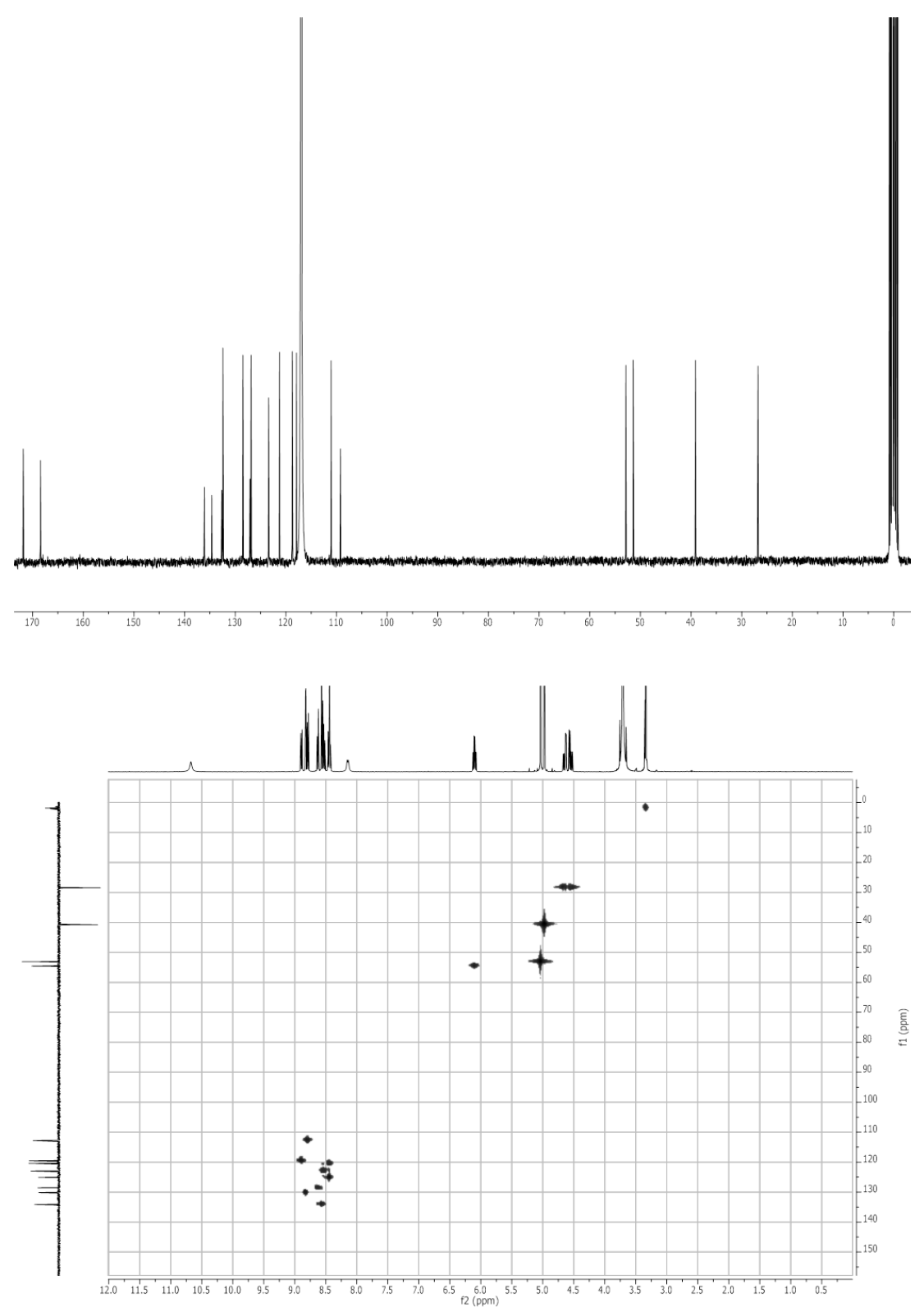

\section{A.6 Model dyad 6}

${ }^{1} \mathrm{H}-\mathrm{NMR}\left(300 \mathrm{MHz}, \mathrm{CD}_{3} \mathrm{CN}\right) \delta 9.25(\mathrm{br} \mathrm{s}, 1 \mathrm{H}), 7.67-7.09(\mathrm{~m}, 7 \mathrm{H}), 5.34(\mathrm{~d}, \mathrm{~J}=$ $12 \mathrm{~Hz}, 1 \mathrm{H}), 4.56(\mathrm{dt}, \mathrm{J}=12 \mathrm{~Hz}, \mathrm{~J}=3 \mathrm{~Hz}, 1 \mathrm{H}), 3.73(\mathrm{~d}, \mathrm{~J}=18 \mathrm{~Hz}, 1 \mathrm{H}), 3.70(\mathrm{~s}$, $3 \mathrm{H}), 3.45\left(\mathrm{dd}, \mathrm{J}=15 \mathrm{~Hz}, \mathrm{~J}^{\prime}=3 \mathrm{~Hz}, 1 \mathrm{H}\right), 3.41(\mathrm{~d}, \mathrm{~J}=18 \mathrm{~Hz}, 1 \mathrm{H}), 2.45$ (dd, J = $15 \mathrm{~Hz}, \mathrm{~J}=12 \mathrm{~Hz}, 1 \mathrm{H})$. 
APPENDIX A. APPENDIX CHAPTER 4
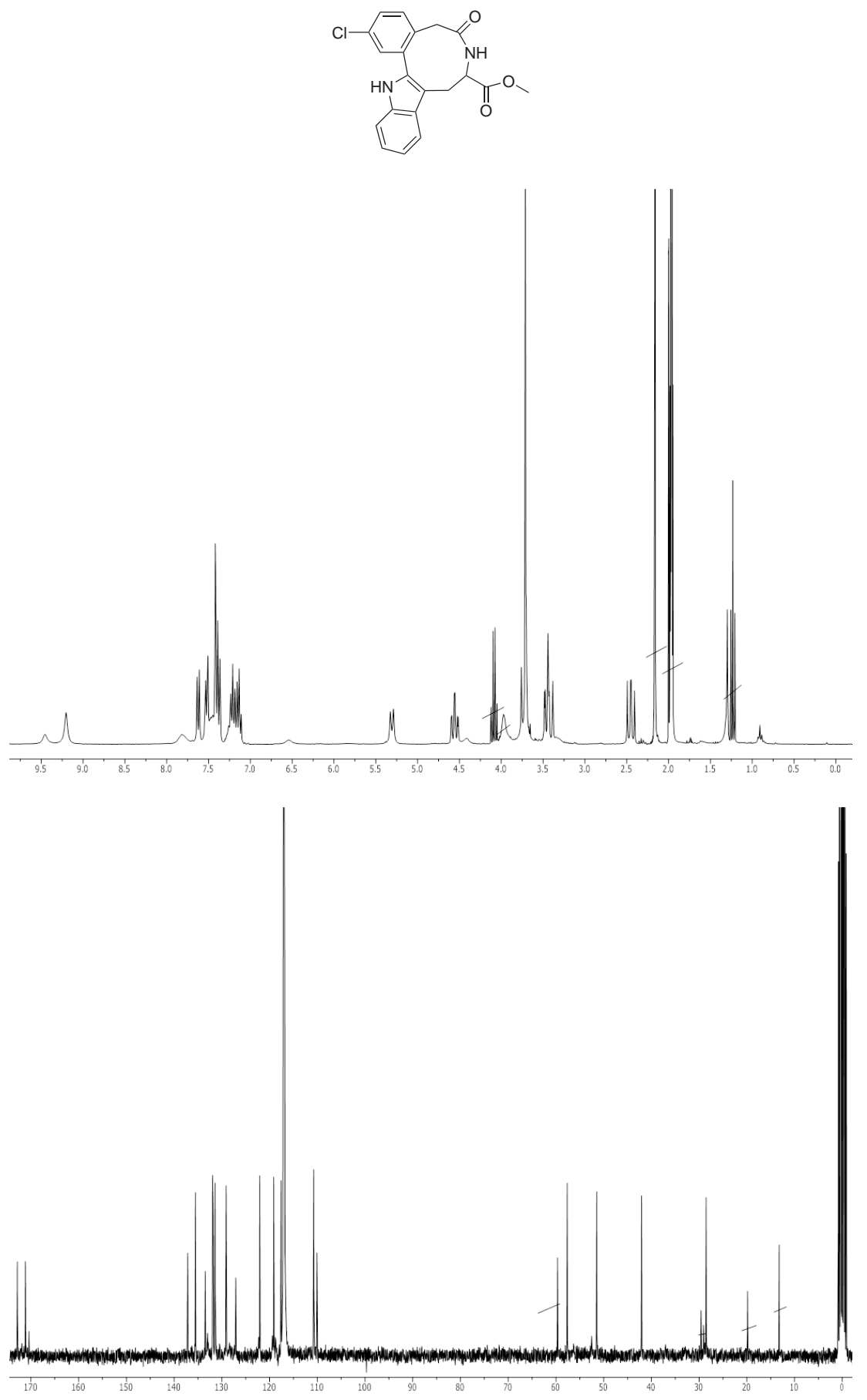

98 


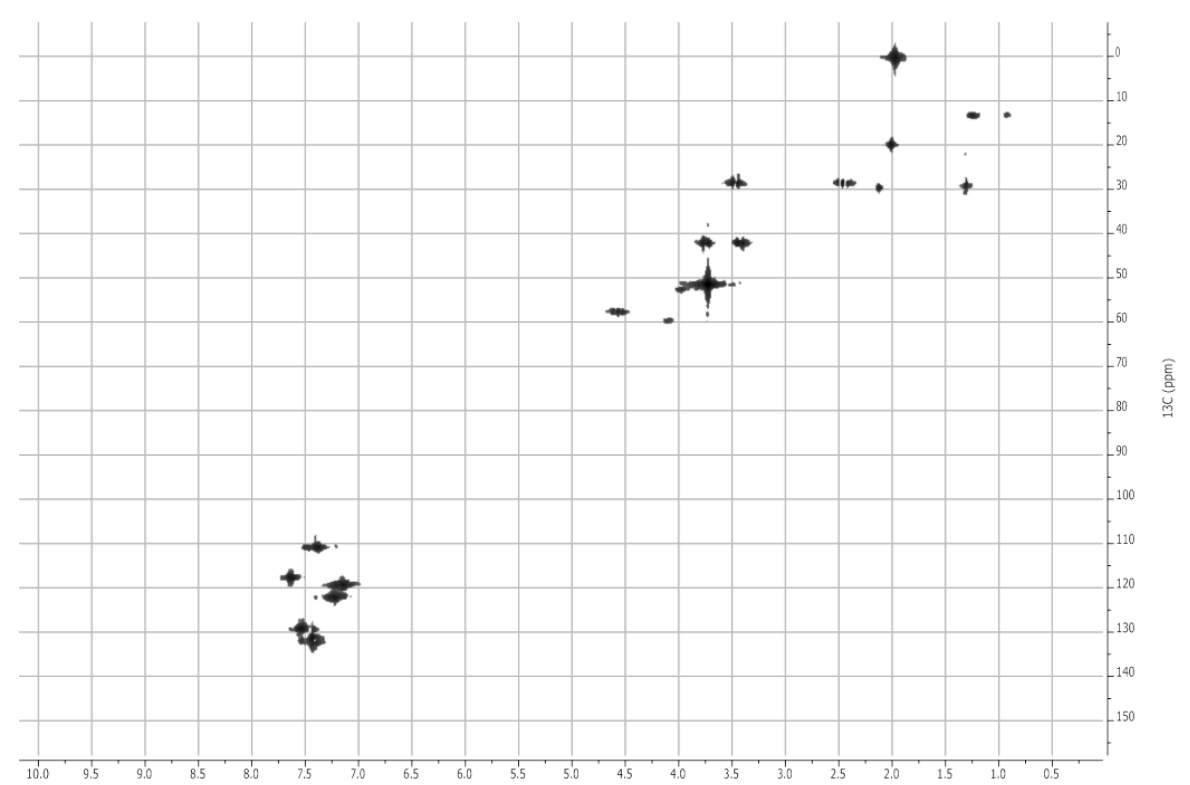

${ }^{13} \mathrm{C}-\mathrm{NMR}\left(75 \mathrm{MHz}, \mathrm{CD}_{3} \mathrm{CN}\right) \delta 172.9(\mathrm{C}), 171.2(\mathrm{C}), 137.2(\mathrm{C}), 135.5(\mathrm{C}), 133.5$ (C), $131.9(\mathrm{CH}), 131.8(\mathrm{C}), 131.4(\mathrm{CH}), 129.1(\mathrm{CH}), 127.1(\mathrm{C}), 122.1(\mathrm{CH}), 119.1$ $(\mathrm{CH}), 117.6(\mathrm{CH}), 110.8(\mathrm{CH}), 110.8(\mathrm{C}), 110.1(\mathrm{C}), 57.6(\mathrm{CH}), 51.4(\mathrm{CH} 3), 42.1$ (CH2), 28.5 (CH2).

HRMS (ESI ${ }^{+}$) Calculated for $\mathrm{C}_{20} \mathrm{H}_{18} \mathrm{ClN}_{2} \mathrm{O}_{3}(\mathrm{M}+\mathrm{H})^{+}$: 369.1006, Found: 369.1002. 


\section{Appendix B}

\section{Appendix of chapter 5}

\section{B.1 2-phenylaminopyrimidine (1)}<smiles>c1ccc(Nc2ncccn2)cc1</smiles>

Aminopyrimidine (0.210 g, $2.2 \mathrm{mmol})$, CuI (0.095 g, $0.5 \mathrm{mmol})$ and anhydrous $\mathrm{K}_{2} \mathrm{CO}_{3}(0.552 \mathrm{~g}, 4 \mathrm{mmol})$ were added to two neck flask fitted with magnetic stirbar and septum. The flask was evacuated and back filled with $\mathrm{N}_{2}$ three times. Dioxane (10 mL), bromobenzene (0.314 g, $2.0 \mathrm{mmol}, 0.21 \mathrm{~mL})$ and DMEDA (0.044 g, 0.5 mmol, $0.053 \mathrm{~mL})$ were added with syringe at room temperature. The reaction mixture was stirred at reflux for $22 \mathrm{~h}$, and cooled to room temperature. Concentrated ammonia $(4 \mathrm{~mL})$ and brine $(20 \mathrm{~mL})$ were added, and the mixture was extracted with ethyl acetate $(3 \times 15 \mathrm{~mL})$. The organic layers were concentrated in vacuo, and the crude product was purified by column chromatography on silica gel (ethyl acetate: dichloromethane 1:20 v/v, Rf: 0.25$)$, and crystallized from $n$-hexane, to provide $0.168 \mathrm{~g}$ ( $49 \%$ yield) product.

${ }^{1} \mathrm{H}-\mathrm{NMR}\left(300 \mathrm{MHz}, \mathrm{CDCl}_{3}\right) \delta 8.37(\mathrm{~d}, \mathrm{~J}=4.8,2 \mathrm{H}), 7.00-7.69(\mathrm{~m}, 6 \mathrm{H}), 6.67$ $(\mathrm{t}, \mathrm{J}=4.8,1 \mathrm{H}) ;{ }^{13} \mathrm{C}-\mathrm{NMR}\left(75 \mathrm{MHz}, \mathrm{CDCl}_{3}\right) \delta 159.9,157.9,139.2,128.9,122.9$, 119.6, 112.5. HRMS $\left(\mathrm{ESI}^{+}\right)$Calculated for $C_{10} H_{10} N_{3}(\mathrm{M}+\mathrm{H})^{+}: 172.0875$; found 172.0870 . 

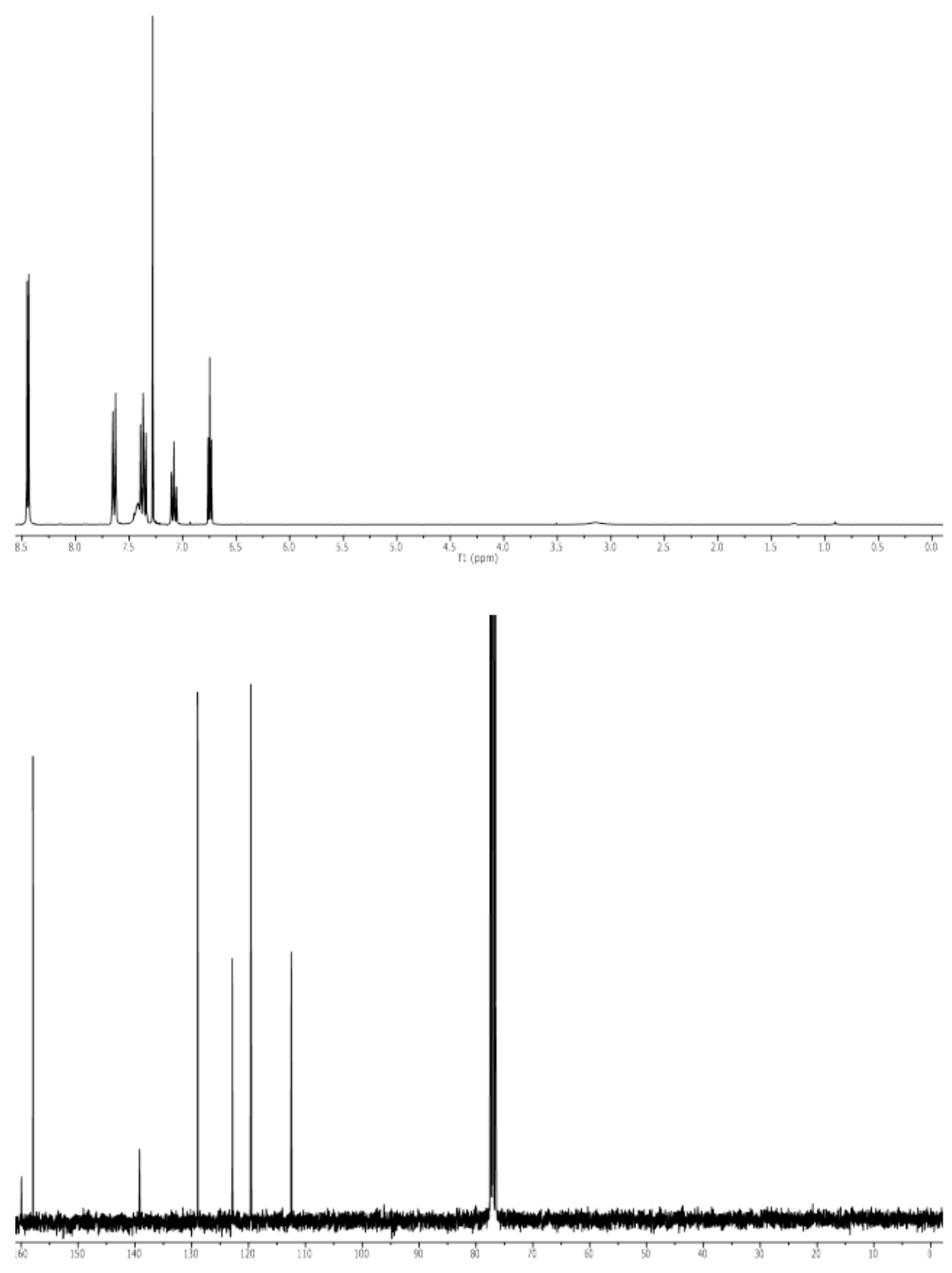

\section{B.2 4-(Pyridin-2-yl)-2-aminopyrimidine (2)}

3-(dimethylamino)-1-(pyridin-2-yl) prop-2-en-1-one (0.4 g, $2.3 \mathrm{mmol})$ and guanidinium hydrochloride $(0.23 \mathrm{~g}, 2.4 \mathrm{mmol}, 1.05$ eq. $)$ were mixed in $5 \mathrm{~mL}$ of 2propanol. To the suspension was added $0.11 \mathrm{~g}$ of $\mathrm{NaOH}(2.7 \mathrm{mmol}, 1.2 \mathrm{eq}$.$) and$ the mixture was refluxed for $18 \mathrm{~h}$. The reaction was then cooled to $0^{\circ} \mathrm{C}$ and the 
<smiles>Nc1nccc(-c2ccccn2)n1</smiles>

precipitate was filtered off, suspended in water, filtered off once more and washed with 2-propanol and diethyl ether. The residue was dried in a vacuum desiccator and the desired product was obtained as a white powder $(0.24 \mathrm{~g}$, yield $=61 \%)$.

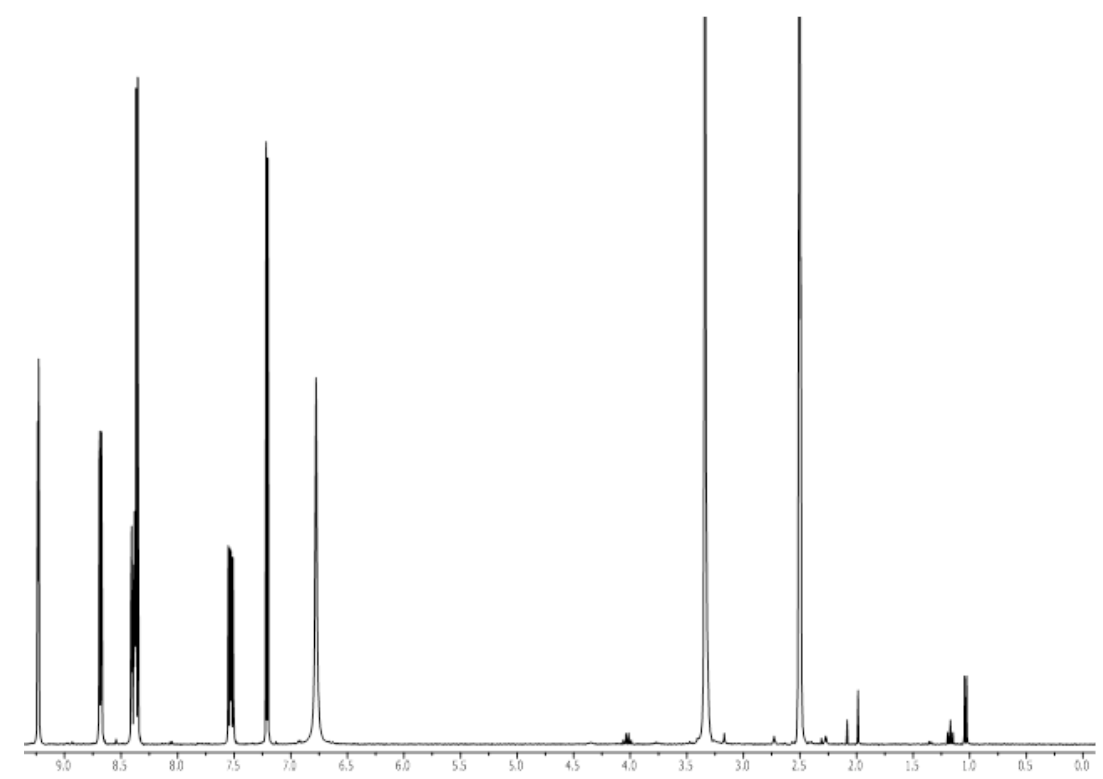

TLC (ethyl acetate/acetonitrile 2/1 v/v) Rf: 0.40. ${ }^{1} \mathrm{H}-\mathrm{NMR}(300 \mathrm{MHz}$, DMSO-d $\left.{ }_{6}\right) \delta 9.23(\mathrm{dd}, \mathrm{J}=2.3,0.9 \mathrm{~Hz}, 1 \mathrm{H}), 8.68(\mathrm{dd}, \mathrm{J}=4.8,1.7 \mathrm{~Hz}, 1 \mathrm{H}), 8.39$ (ddd, $\mathrm{J}=8.1,2.4,1.7 \mathrm{~Hz}, 1 \mathrm{H}), 8.36(\mathrm{~d}, \mathrm{~J}=5.1 \mathrm{~Hz}, 1 \mathrm{H}), 7.53$ (ddd, J = 8.0, 4.8, $0.9 \mathrm{~Hz}, 1 \mathrm{H}), 7.21(\mathrm{~d}, \mathrm{~J}=5.1 \mathrm{~Hz}, 1 \mathrm{H}), 6.78(\mathrm{bb}, 2 \mathrm{H}) ; ;{ }^{13} \mathrm{C}-\mathrm{NMR}(75 \mathrm{MHz}$, DMSO$\left.\mathrm{d}_{6}\right) \delta 163.8,161.5,159.3,151.1,147.9,134.1,132.4,123.7,106.0$, HRMS $\left(\mathrm{ESI}^{+}\right)$ Calculated for $\mathrm{C}_{9} \mathrm{H}_{9} \mathrm{~N}_{4}(\mathrm{M}+\mathrm{H})^{+}$: 173.0827 ; found 173.0827 . 


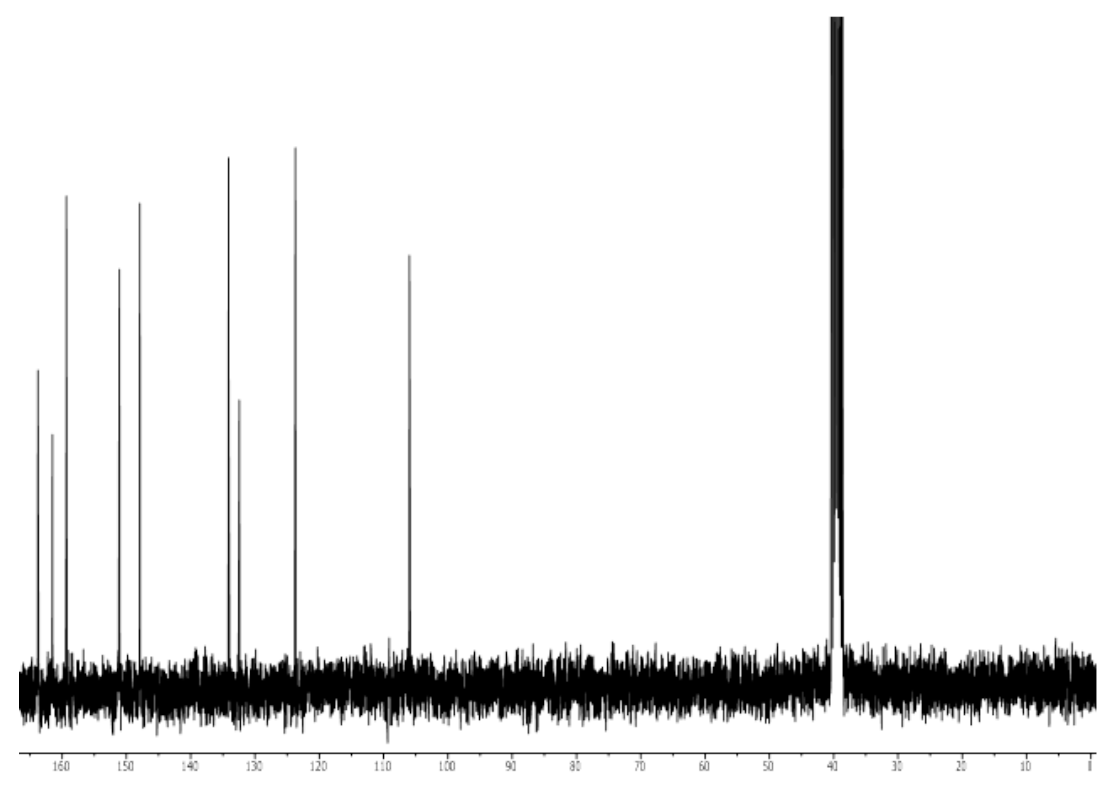

\section{B.3 N-(3-aminophenyl)benzamide (3)}<smiles>Nc1cccc(NC(=O)c2ccccc2)c1</smiles>

A solution of benzoyl chloride $(0.24 \mathrm{~g}, 1.7 \mathrm{mmol}, 0.2 \mathrm{~mL})$ and activated zinc $(0.11 \mathrm{~g}, 1.7 \mathrm{mmol})$ in $5 \mathrm{~mL}$ of anhydrous toluene was added dropwise to a magnetically stirred solution of the benzene-1,3-diamine $(0.11 \mathrm{~g}, 3.6 \mathrm{mmol})$ in $5 \mathrm{~mL}$ anhydrous toluene. The mixture stirred at room temperature for $18 \mathrm{~h}$, the progress of the reaction was monitored by TLC. After completion of the reaction, it was filtered and the solid cake washed with ether $(50 \mathrm{~mL})$. The combined filtrate was extracted with saturated bicarbonate solution and dried over $\mathrm{MgSO}_{4}$. The organic layers were concentrated in vacuo, and the crude product was purified by column chromatography on silica gel (ethyl acetate: n-hexane 1:1 v/v, Rf: 0.35) and crystallized from toluene $/ n$-hexane at $4^{\circ} \mathrm{C}$, to provide $0.240 \mathrm{~g}(67 \%$ yield) of product 3.

${ }^{1} \mathrm{H}-\mathrm{NMR}\left(300 \mathrm{MHz}, \mathrm{CDCl}_{3}\right) \delta$ 7.90-7.80 (m, 2H), $7.77(\mathrm{bb}, 1 \mathrm{H}), 7.59-7.40(\mathrm{~m}$, $3 \mathrm{H}$ ), 7.31 (t, J = 2.2 Hz, 1H), 7.12 (t, J = 8.0 Hz, 1H), 6.79 (ddd, J = 8.0, 2.0, 0.9 $\mathrm{Hz}, 1 \mathrm{H}), 6.47$ (ddd, J = 8.0, 2.3, $0.9 \mathrm{~Hz}, 1 \mathrm{H}), 3,74(\mathrm{bb}, 2 \mathrm{H}) . ;{ }^{13} \mathrm{C}-\mathrm{NMR}(75 \mathrm{MHz}$, $\left.\mathrm{CDCl}_{3}\right) \delta 165.7,147.3,138.9,135.2,131.8,129.8,128.8,126.9,111.3,110.0,106.8$. HRMS $\left(\mathrm{ESI}^{+}\right.$) Calculated for $\mathrm{C}_{13} \mathrm{H}_{13} \mathrm{~N}_{2} \mathrm{O}(\mathrm{M}+\mathrm{H})^{+}:$: 213.1028; found 213.1027. 

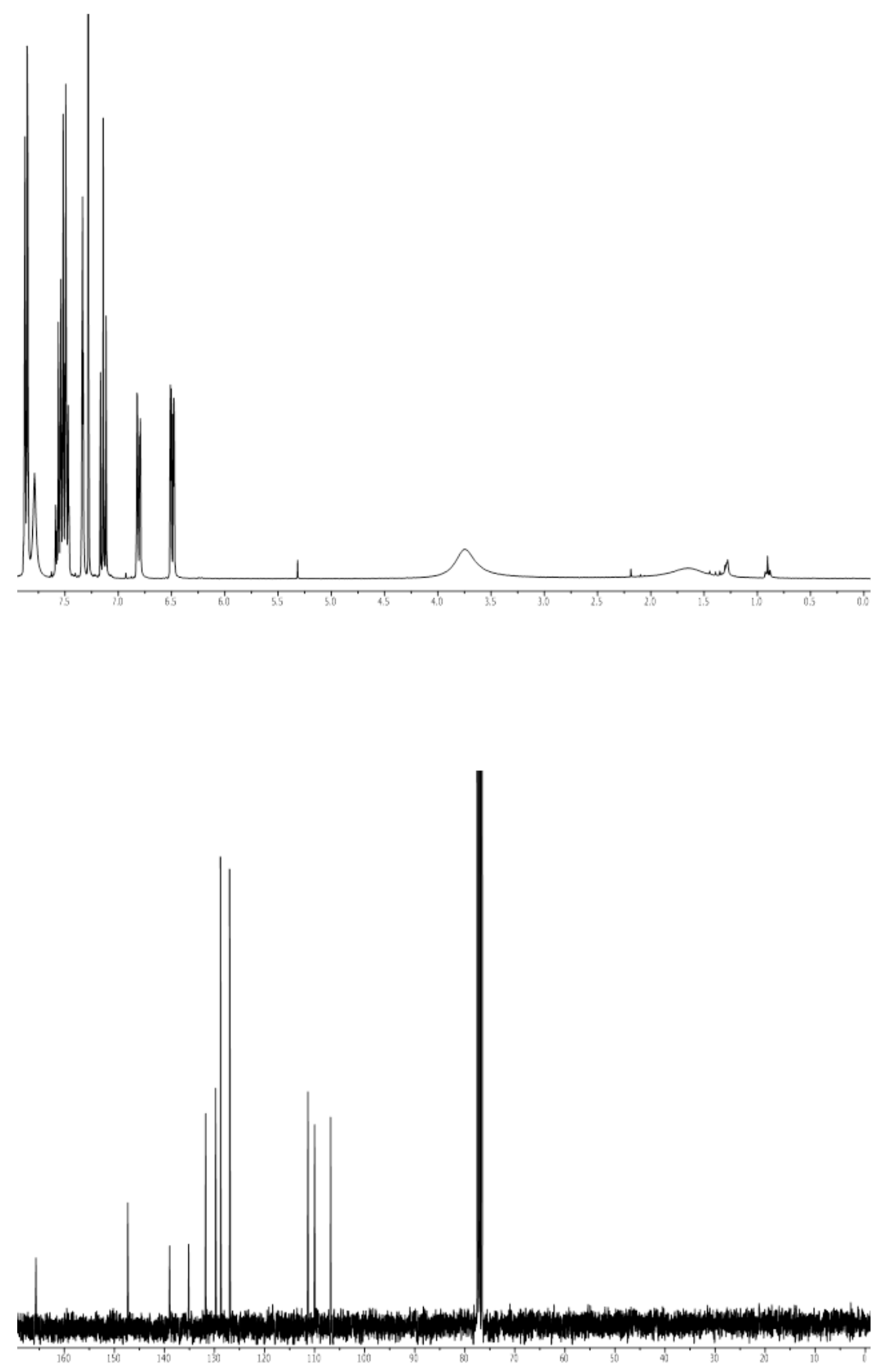


\section{Appendix C}

\section{Appendix of chapter 6}

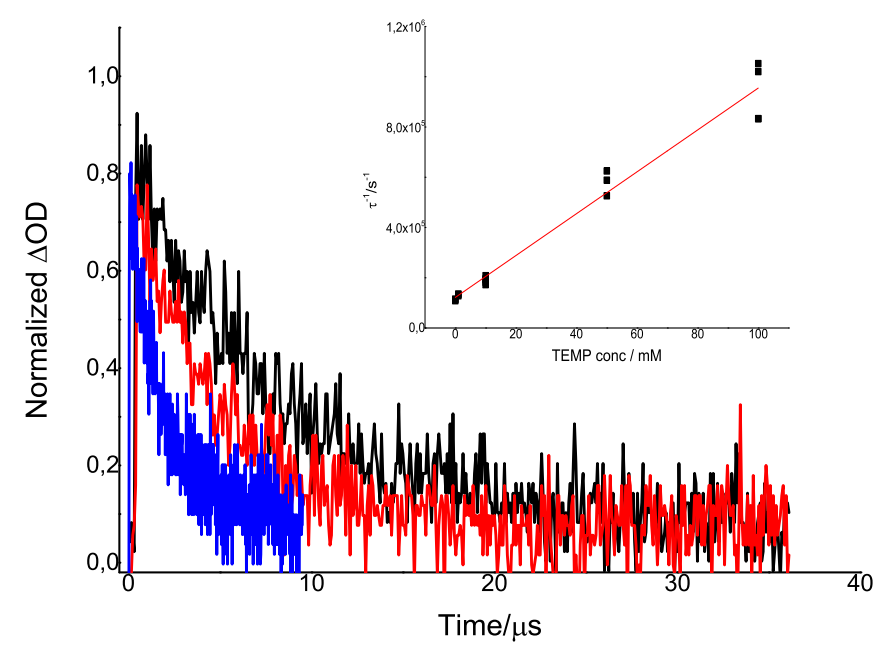

Figure C.1: Normalized T-T absorption decay ( $\lambda_{e x}=355 \mathrm{~nm}$, monitored at $480 \mathrm{~nm}$ ) of argonbubbled ACN solution of PN $\left(2.1 \times 10^{-5} \mathrm{M}\right)$ with increasing amount of TEMP: 0 (black), 10 (red), 50 (blue) $\mathrm{mM}$. Inset: plot of the triplet decay rate constant vs. concentration of quencher. 


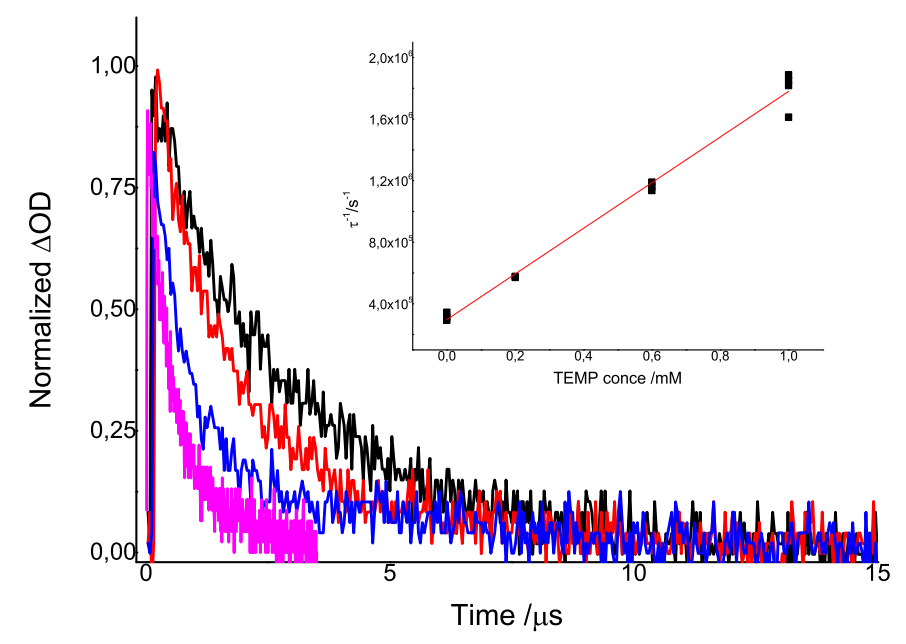

Figure C.2: Normalized T-T absorption decay $\left(\lambda_{e x}=355 \mathrm{~nm}\right.$, monitored at $\left.530 \mathrm{~nm}\right)$ of argonbubbled ACN solution of BP $\left(3.1 \times 10^{-3} \mathrm{M}\right)$ with increasing amount of TEMP 0 (black), 0.2 (red), 0.6 (blue), 1 (purple) $\mathrm{mM}$. Inset: plot of triplet decay rate constant vs. concentration of quencher

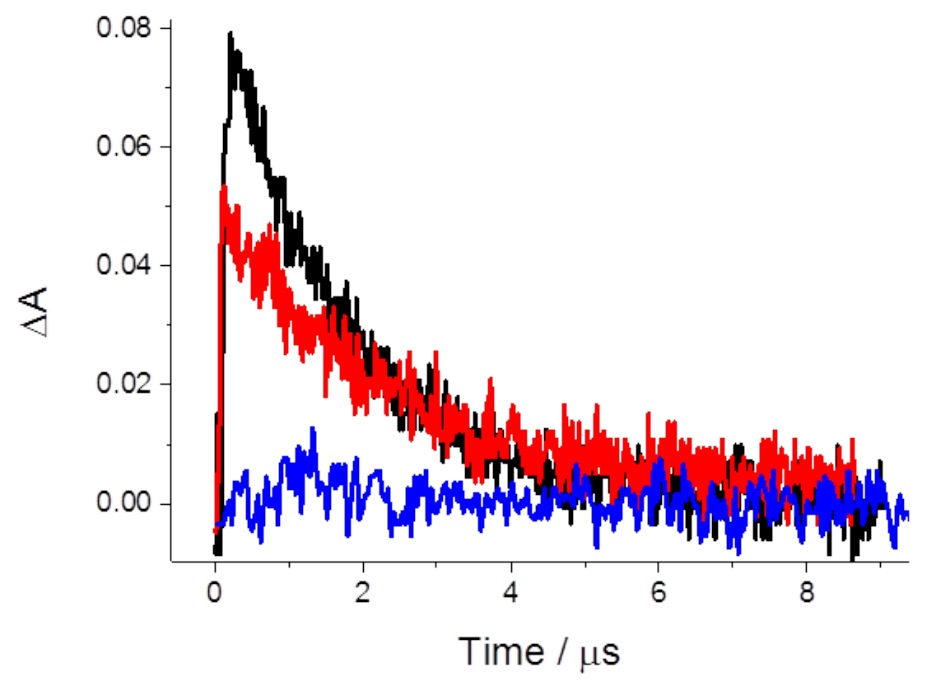

Figure C.3: T-T absorption decay $\left(\lambda_{e x}=266 \mathrm{~nm}\right.$, monitored at $\left.415 \mathrm{~nm}\right)$ of argon-bubbled ACN solution of $N P\left(7.1 \times 10^{-3} \mathrm{M}\right)$ with increasing amount of TEMP: 0 (black), 10 (red), 50 (blue) $m M$. 


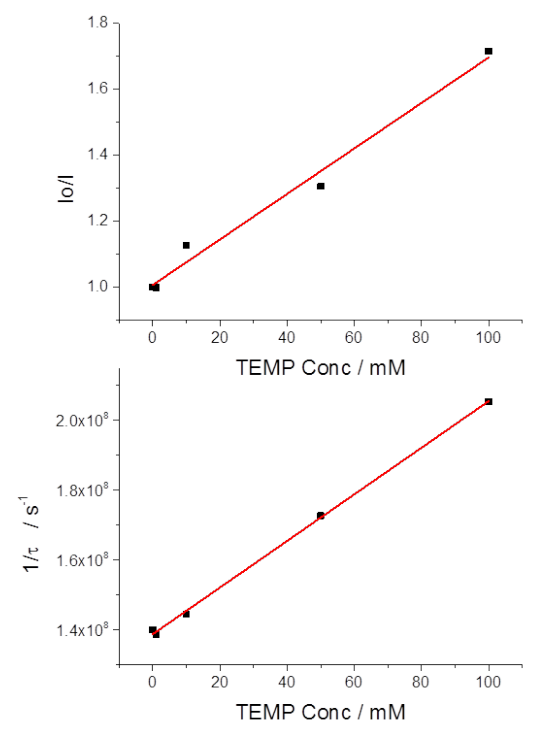

Figure C.4: Stern-Volmer plots of CBZ $\left(3.5 \times 10^{-5} \mathrm{M}\right)$ in the presence of TEMP obtained from steady-state (top) and time-resolved fluorescence (bottom) experiments.
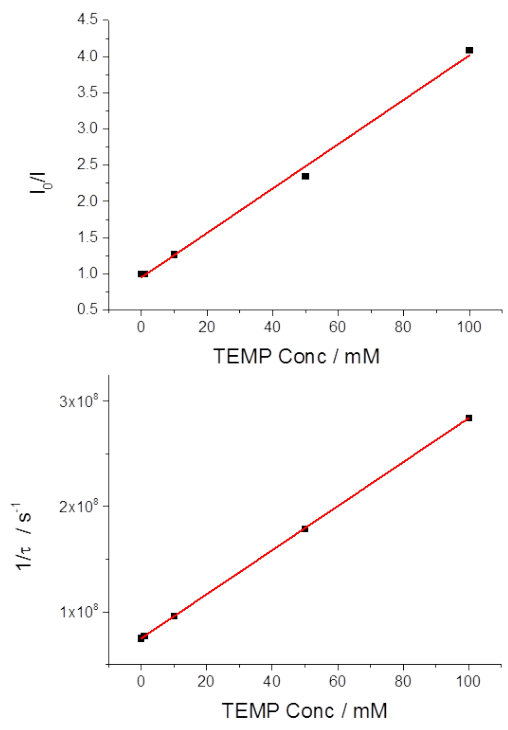

Figure C.5: Stern-Volmer plots of NP $\left(2.3 \times 10^{-6} \mathrm{M}\right)$ in the presence of TEMP obtained from steady-state (top) and time-resolved fluorescence (bottom) experiments. 


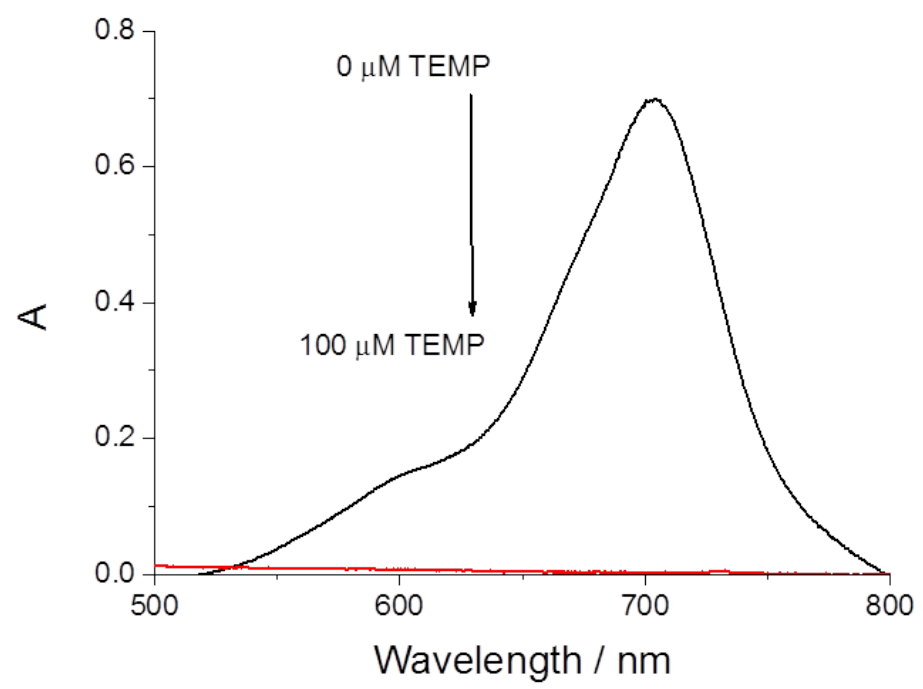

Figure C.6: UV absorption spectra of an acetonitrile solution of BAHA (100 $\mu M)$ in the absence (black) and in the presence (red) of a stoichiometric amount of TEMP.

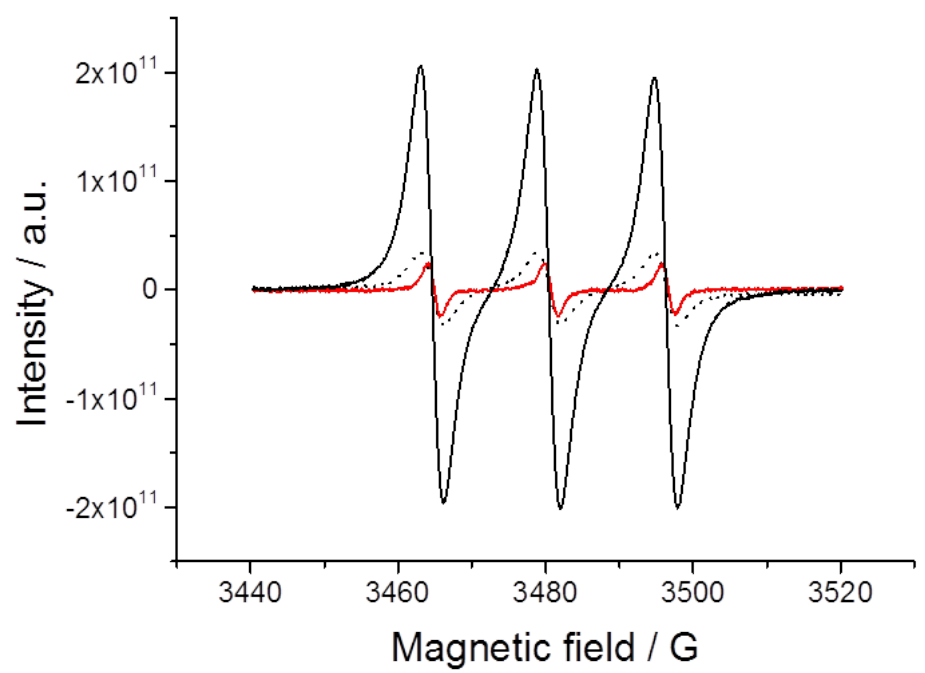

Figure C.7: TEMPO/EPR signals obtained for ACN solution of TEMP (50 mM) without (dotted line) and in the presence of $5 \mathrm{mM} B A H A$ under aerobic (red line) or anaerobic conditions (black line). 


\section{Appendix D}

\section{Publications}

This thesis gave rise to the following publications:

1. Potential phototoxicity of rosuvastatin mediated by its dihydrophenanthrenelike photoproduct; Giacomo Nardi; Virginie Lhiaubet-Vallet; Paula LeandroGarcia; Miguel A. Miranda Chem. Res. Toxicol., 2011, 24, 1779-1785

2. Generation of reactive aryl radical intermediates in the reductive photodehalogenation of itraconazole ; Giacomo Nardi; M. Luisa Marin; Pierre A. de Souza; Virginie Lhiaubet-Vallet; Miguel A. Miranda; RSC Adv., 2014, 4, 2687-2693

3. Photosensitization by imatinib. A photochemical and photobiological study on the drug and its substructures, Giacomo Nardi; Virginie Lhiaubet-Vallet; Miguel A. Miranda,Chem.Res.Toxicol., 2014, 27, 1990-1995

4. Scope and limitations of the TEMPO/EPR method for singlet oxygen detection: the misleading role of electron transfer, Giacomo Nardi; Ilse Manet; Sandra Monti; Miguel A. Miranda; Virginie Lhiaubet-Vallet, Free Radic. Biol. Med., 2014, 77, 64-70 


\section{Bibliography}

[1] Turro N.J.; Ramamurthy V.; Scaiano J.C. Modern Molecular Photochemistry of Organic Molecules. University Science Books, Sausalito, California, 2010.

[2] Ford W.; Rihter B.; Rodgers M.; Kenney M. Quenching of naphthalocyanine triplets by $\mathrm{O}_{2}$ - application of the Sandros equation. J. Am. Chem. Soc, 111:2362, 1989 .

[3] Rehm D.; Weller A. Kinetics of fluorescence quenching by electron and hatom transfer. Isr. J. Chem, 8:259, 1970.

[4] Lhiaubet Vallet V.; Miranda M. A. Phototoxicity of drugs. CRC Handbook of Organic Photochemistry and Photobiology; 3rd Edition, A. Griesbeck; M. Oelgemoller ;F. Ghetti edition, 2012.

[5] Cadet J.; Douki T.; Ravanat J.L. Oxidatively generated damage to the guanine moiety of DNA: Mechanistic aspects and formation in cells. Acc. Chem. Res, 41:1075, 2008.

[6] Y. Shahidi, F.; Zhong. Lipid oxidation and improving the oxidative stability. Chem. Soc. Rev., 39:4067, 2010.

[7] Davies M. J. Reactive species formed on proteins exposed to singlet oxygen. Photochem. Photobiol. Sci., 3:17, 2004.

[8] Ferlay J.; Steliarova-Foucher E.; Lortet-Tieulent J.; Rosso S.; Coebergh J.W.W.; Comber H.; Forman D.; Bray F. Cancer incidence and mortality patterns in Europe: Estimates for 40 countries in 2012. Eur. J. Cancer, $2: 75,2013$.

[9] Quintero B.; Miranda M.A. Mechanisms of photosentization induced by drugs: a general survey. Ars Pharm., 41:27, 2000.

[10] Istvan E. S.; Deisenhofer J. Structural mechanism for statin inhibition of HMG-CoA reductase. Science, 292:1160, 2001.

[11] Granados M. T. R.; de la Torre C.; Cruces M. J.; Pineiro G. Chronic actinic dermatitis due to simvastatin. Contact Dermatitis, 38:294, 1998. 
[12] Holme S. A.; Pearse A. D.; Anstey A. V. Chronic actinic dermatitis secondary to simvastatin. Photodermatol., Photoimmunol. Photomed., 18:313, 2002.

[13] Morimoto K.; Kawada A.; Hiruma A.; Ishibashi A.; Banba H. Photosensitivity to simvastatin with an unusual response to photopatch and phototests. Contact Dermatitis, 33:274, 1995.

[14] Roger D.; Rolle F.; Labrousse F.; Brosset A.; Bonnetblanc J. M. Simvastatininduced lichenoid drug eruption. Clin. Exp. Dermatol., 19:88, 1994.

[15] Marguery M. C.; Chouini-Lalanne N.; Drugeon C.; Gadroy A.; Bayle P.; Journe F.; Bazex J.; D'Incan M. UVB phototoxic effects induced by atorvastatin. Arch. Dermatol., 142:1082, 2006.

[16] Rodriguez-Pazos L.; Sanchez-Aguilar D.; Rodriguez-Granados M.; PereiroFerreiros M.; Toribio J. Erythema multiforme photoinduced by statins. Photodermatol. Photoimmunol. Photomed., 26:216, 2010.

[17] Del Rio R.; Palou J.; Lecha M. Fotosensibilidad por estatinas. Boletin GEF, page 32, 1998.

[18] Quiec D.; Maziere C.; Auclair M.; Santus R.; Gardette J.; Redziniak G.; Franchi J.; Dubertret L.; Maziere J. C. Lovastatin enhances the photocytotoxicity of UVA radiation towards cultured N.C.T.C. 2544 human keratinocytes: prevention by cholesterol supplementation and by a cathepsin inhibitor. Biochem. J., 310:305, 1995.

[19] Chignell C. F.; Kukielczak B. M.; Sik R. H.; Bilski P. J.; He Y.-Y. Ultraviolet a sensitivity in smith-lemli-opitz syndrome: Possible involvement of cholesta5,7,9(11)-trien-3[beta]-ol. Free Radic. Biol. Med., 41:339, 2006.

[20] Viola G.; Grobelny P.; Linardi M. A.; Salvador A.; Basso G.; Mielcarek J.; Dall'Acqua S.; Vedaldi D.; Dall'Acqua F. The phototoxicity of fluvastatin, an hmg-coa reductase inhibitor, is mediated by the formation of a benzocarbazole-like photoproduct. Toxicol. Sci., 118:236, 2010.

[21] Cermola F.; DellaGreca M.; Iesce M. R.; Montanaro S.; Previtera L.; Temussi F. Photochemical behavior of the drug atorvastatin in water. Tetrahedron, 62:7390, 2006.

[22] Montanaro S.; Lhiaubet-Vallet V.; Iesce M.; Previtera L.; Miranda M. A. A mechanistic study on the phototoxicity of atorvastatin: singlet oxygen generation by a phenanthrene-like photoproduct. Chem. Res. Toxicol., 22:173, 2008 .

[23] Bosca F.; Encinas S.; Heelis P. F.; Miranda M. A. Photophysical and photochemical characterization of a photosensitizing drug: a combined steady state photolysis and laser flash photolysis study on carprofen. Chem. Res. Toxicol., 10:820, 1997. 
[24] Moser P.; Sallmann A.; Wiesenberg I. Synthesis and quantitative structureactivity-relationships of diclofenac analogs. J. Med. Chem., 33:2358, 1990.

[25] Przybilla B.; Ring J; Schwab U;. Evaluation of photosensitizing properties of nonsteroidal antiinflammatory drugs by photopatch testing. Hautarzt, 38:18, 1987.

[26] Ljunggren B.; Lundberg K. In vivo phototoxicity of nonsteroidal antiinflammatory drugs evaluated by the mouse tail technique. Photodermatology, $2: 377,1992$.

[27] Moore D.E.; Roberts Thomson S.; Zhen D;. Photochemical studies on the antiinflammatory drug diclofenac. Photochem.Photobiol., 52:685, 1990.

[28] Encinas S.; Bosca F.; Miranda M.A. Phototoxicity associated with diclofenac: a photophysical, photochemical, and photobiological study on the drug and its photoproducts. Chem. Res. Toxicol., 11:946, 1998.

[29] Martin M.; Breheret E.; Tfibel F; Lacourbas B. Two-photon stepwise dissociation of carbazole in solution. J. Phys. Chem., 84:70, 1980.

[30] Astarita A.; DellaGreca M.; Iesce M. R.; Montanaro S.; Previtera L.; Temussi F. Polycyclic compounds by sunlight exposure of the drug rosuvastatin in water. J. Photochem. Photobiol. A, 187:263, 2007.

[31] Fornier de Violet P.; Bonneau R.; Lapouyade R.; Koussini R.; Ware W. R. Intramolecular photocyclization of 2-vinylbiphenyl-like compounds. 2. Detection of the intermediates and kinetic study by laser flash photolysis of 1-(o-diphenyl)-1-phenylethylene. J. Am. Chem. Soc., 100:6683, 1978.

[32] Lewis F. D.; Zuo X. Conformer-specific photoisomerizaton of some 2vinylbiphenyls. Photochem. Photobiol. Sci., 2:1059, 2003.

[33] Bosca F.; Marin M. L.; Miranda M. A. Photoreactivity of the nonsteroidal anti-inflammatory 2-arylpropionic acids with photosensitizing side effects. Photochem. Photobiol., 74:637, 2001.

[34] Schmidt R.; Tanielian C.; Dunsbach R.; Wolff C. Phenalenone, a universal reference compound for the determination of quantum yields of singlet oxygen $\mathrm{O}_{2}\left({ }^{1} \Delta_{g}\right)$ sensitization. J. Photochem. Photobiol. A, 79:11, 1994.

[35] Cuquerella M. C.; Lhiaubet-Vallet V.; Bosca F.; Miranda M. A. Photosensitised pyimidine dimerisation in DNA. Chem. Sci., 2:1219, 2011.

[36] Tsentalovich Y. P.; Snytnikova O. A.; Sagdeev R. Z. Properties of excited states of aqueous tryptophan. J. Photochem. Photobiol. A, 162:371, 2004.

[37] Carmichael I.; Hug G. L. Triplet-triplet absorption spectra of organic molecules in condensed phases. J. Phys. Chem. Ref. Data, 15:1, 1986. 
[38] Montalti M.; Credi A.; Prodi L.; Gandolfi M.T. Handbook of Photochemistry, Third Edition. CRC Press, 2006.

[39] Lion Y.; Delmelle M.; Van de Vorst A. New method of detecting singlet oxygen production. Nature, 263:442, 1976.

[40] Aftab B.T.;Dobromilskaya I.; Liu J.O.; Rudin C.M. Itraconazole inhibits angiogenesis and tumor growth in non-small cell lung cancer. Cancer. Res., 71:6764, 2011.

[41] Nacev B.A.; Grassi P.; Dell A.; Haslam S.M.;Liu J.O. The antifungal drug itraconazole inhibits vascular endothelial growth factor receptor 2 (VEGFR2) glycosylation, trafficking, and signaling in endothelial cells. J.Biol.Chem., 286:44045, 2011.

[42] Alvarez-Fernandez J.; Castano-Suarez E.; Cornejo-Navarro P.; Gomez de la Fuente E.; Ortiz de Frutos F; Iglesias-Diez L. Photosensitivity induced by oral itraconazole. J. Eur. Acad. Dermatol. Venereol., 14:501, 2000.

[43] Drucker A.M.; Rosen C. F. Drug-induced photosensitivity culprit drugs, management and prevention. Drug Safety, 34:821, 2011.

[44] Epaulard O.; Leccia M; Blanche S.; Chosidow O.; Mamzer-Bruneel M.; Ravaud P.; Thiebaut A.; Villier C.; Lortholary O. Phototoxicity and photocarcinogenesis associated with voriconazole. Medecine et Maladies Infectieuses, 41:639, 2011.

[45] Mohamed K. N. Severe photodermatitis during ketoconazole therapy. Clin. Exp. Dermatol., 13:54, 1988.

[46] Da Silva J.P.; Da Silva A.M.; Khmelinskii I.; Martinho J.; Ferreira L. Photophysics and photochemistry of azole fungicides: triadimefon and triadimenol. J. Photochem. Photobiol. A, 142:31, 2001.

[47] Santoro A.; Scopa A.; Bufo S.A.; Mansour M.; Mountacer H. Photodegradation of the triazole fungicide hexaconazole. Bull. Environ. Contam. Toxicol., $64: 475,2000$.

[48] Staub I.; Flores L.; Gosmann G.; Pohlmann A.; Froeehlich P.; Schapoval E.; Bergold A. Photostability studies of ketoconazole: Isolation and structural elucidation of the main photodegradation products. Lat. Amer. J. Pharm., 29:1100, 2010.

[49] Vialaton D.; Pilichowski J.F.; Baglio D.; Paya-Perez A.; Larsen B.; Richard C. Phototransformation of propiconazole in aqueous media. J. Agr. Food Chem., 49:5377, 2001.

[50] Moore D.; Roberts Thomson S.; Zhen D.; Duke C. Photochemical studies on the antinflammatory drug diclofenac. Photochem. Photobiol., 52:685, 1990. 
[51] Andreu I.; Morera I. M.; Bosca F.; Sanchez L.; Camps P.; Miranda M.A. Cholesteroldiaryl ketone stereoisomeric dyads as models for clean type I and type II photooxygenation mechanisms. Org. Biomol. Chem., 6:860, 2008.

[52] Lhiaubet-Vallet V.; Bosca F.; Miranda M. A. Stereodifferentiating drug biomolecule interactions in the triplet excited state: Studies on supramolecular carprofen/protein systems and on carprofen-tryptophan model dyads. J. Phys. Chem. B, 111:423, 012007.

[53] Andreu I.; Mayorga C.; Miranda M. A. Generation of reactive intermediates in photoallergic dermatitis. Curr. Opin. Allergy. Clin. Immunol., 10:303, 2010.

[54] Caffieri S.; Miolo G.; Seraglia R.; Dalzoppo D.; Toma F.; Van Henegouwen G. Photoaddition of fluphenazine to nucleophiles in peptides and proteins possible cause of immune side effects. Chem. Res. Toxicol., 20:1470, 2007.

[55] Montanaro S.; Lhiaubet-Vallet V.; C. Jimenez; M. Blanca; Miranda M.A. Photonucleophilic addition of the epsilon-amino group of lysine to a triflusal metabolite as a mechanistic key to photoallergy mediated by the parent drug. ChemMedChem, 4:1196, 2009.

[56] Lhiaubet-Vallet V.; Bosca F.; Miranda M.A. Photosensitized DNA damage: The case of fluoroquinolones. Photochem. Photobiol., 85:861, 2009.

[57] Goerner H. Photoinduced oxygen uptake of diphenylamines in solution and their ring closure revisited. J. Phys. Chem. A, 112:1245, 2008.

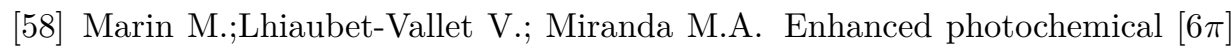
electrocyclization within the lipophilic protein binding site. Org. Lett. 14:1788, 2012.

[59] Inkmann E.; Holzgrabe U. H-1 and c-13 nuclear magnetic resonance studies of the sites of protonation in itraconazole and fluconazole. J. Pharm. Biomed., 20:297, 1999.

[60] Stegmeier F.; Warmuth M.; Sellers W. R.; Dorsch M. Targeted cancer therapies in the twenty-first century: lessons from imatinib. Clin. Pharmacol. Ther., 87:543, 2010.

[61] Patel S. Long-term efficacy of imatinib for treatment of metastatic gist. Cancer Chemother. Pharmacol., 72:277, 2013.

[62] Lydon N. Attacking cancer at its foundation. Nat. Med., 15:1153, 2009.

[63] Guilhot F. Indications for imatinib mesylate therapy and clinical management. Oncologist, 9:271, 2004.

[64] Bucci M.; Goodman C.; Sheppard T. L. A decade of chemical biology. Nat. Chem. Biol., 6:847, 2010. 
[65] Lydon N. B.; Druker B. J. Lessons learned from the development of imatinib. Leukemia Res., 28S1:S29, 2000.

[66] Amitay-Laish I.; Stemmer S. M.; Lacouture M. E. Adverse cutaneous reactions secondary to tyrosine kinase inhibitors including imatinib mesylate, nilotinib, and dasatinib. Dermatol. Ther., 24:386, 2011.

[67] Liu L. S.; Colegio O. R. Molecularly targeted therapies for nonmelanoma skin cancers. Int. J. Dermatol., 52:654, 2013.

[68] Valeyrie L.; Bastuji-Garin S.; Revuz J.; Bachot N.; Wechsler J.; Berthaud P.; Tulliez M.; Giraudier S. Adverse cutaneous reactions to imatinib (STI571) in philadelphia chromosome-positive leukemias: A prospective study of 54 patients. J. Am. Acad. Dermatol., 48:201, 2003.

[69] Heidary N.; Naik H.; Burgin S. Chemotherapeutic agents and the skin: An update. J. Am. Acad. Dermatol., 58:545, 2008.

[70] I. Raanani P.; Golman J. M.; Ben-Bassat. Challenges in oncology. Case 3: depigmentation in a chronic myeloid leukemia patient treated with STI571. J. Clin. Oncol., 20:869, 2002.

[71] Rousselot P.; Larghero J.; Raffoux E.; Calvo F.; Tulliez M.; Giraudier S.; Rybojad M. Photosensitization in chronic myelogenous leukaemia patients treated with imatinib mesylate. Br. J. Haematol., 120:1091, 2003.

[72] Brazzelli V.; Muzio F.; Manna G.; Moggio E.; Vassallo C.; Orlandi E.; Fiandrino G.; Lucioni M.; Borroni G. Photoinduced dermatitis and oral lichenoid reaction in a chronic myeloid leukemia patient treated with imatinib mesylate. Photodermatol. Photoimmunol. Photomed., 28:2, 2012.

[73] Timmer de Mik L.; Kardaun S. H.; Kramer M. H. H.; Hayes D. P.; Bousema M. T. Imatinib-induced pseudoporphyria. Clin. Exp. Dermatol., 34:705, 2008 .

[74] Baskaynak G.; Kreuzer K.-A.; Schwarz M.; Zuber J.; Audring H.; Riess H; Dorken B.; Le C. P. Squamous cutaneous epithelial cell carcinoma in two $\mathrm{cml}$ patients with progressive disease under imatinib treatment. Eur. J. Haematol., 70:231, 2003.

[75] Tamura A.; Onishi Y.; An R.; Koshiba S.; Wakabayashi K.; Hoshijima K.; Priebe W.; Yoshida T.; Kometani S.; Matsubara T.; Mikuriya K.; Ishikawa T. In vitro evaluation of photosensitivity risk related to genetic polymorphisms of human ABC transporter ABCG2 and inhibition by drugs. Drug. Metab. Pharmacokinet., 22:428, 2007.

[76] Tamura A.; An R.; Hagiya Y.; Hoshijima K.; Yoshida T.; Mikuriya K.; Ishikawa T. Drug-induced phototoxicity evoked by inhibition of human ABC transporter ABCG2: development of in vitro high-speed screening systems. Expert Opin. Drug. Metab. Toxicol., 4:255, 2008. 
[77] Liu W.; Baer M. R.; Bowman M. J.; Pera P.; Zheng X.; Morgan J.; Pandey R. A.; Oseroff A. R. The tyrosine kinase inhibitor imatinib mesylate enhances the efficacy of photodynamic therapy by inhibiting ABCG2. Clin. Cancer Res., 13:2463, 2007.

[78] Szczepek W. J.; Kosmacinska B.; Bielejewskaa A.; Luniewski W.; Skarzynski M.; Rozmarynowskaa D. Identification of imatinib mesylate degradation products obtained under stress conditions. J. Pharm. Biomed. Anal., 43:1682, 2007.

[79] Kinani A.; Rifai A.; Bourcier S.; Jaber F.; Bouchonnet S. Structural characterization of photoproducts of pyrimethanil. J. Mass Spectrom., 48:983, 2013.

[80] Jimenez M. C.; Miranda M. A. Tormos R.; Vaya I. Characterisation of the lowest singlet and triplet excited state of s flurbiprofen. Photochem. Photobiol. Sci., 3:1038, 2004.

[81] Su T.; Ma J.; Wong N.; Phillips D. L. Time-resolved spectroscopic characterization of a novel photodecarboxylation reaction mediated by homolysis of a carbon $\alpha$-bond in flurbiprofen. J. Phys. Chem. B, 117:8347, 2013.

[82] Zimmermann J.; Buchdunger E.; Mett H.; Meyer T.; Lydon N. B.; Traxler P. Phenylamino-pyrimidine (PAP)-derivatives: a new class of potent and highly selective PDGF-receptor autophosphorylation inhibitors. Bioorg. Med. Chem. Lett., 6:1221, 1996.

[83] Kalesh K. A.; Sim D. S. B.; Wang J.; Liu K.; Lin Q.; Yao S. Q. Small molecule probes that target abl kinase. Chem. Commun., 46:1118, 2010.

[84] Liu Y.; Bai Y.; Zhang J.; Li Y.; Jiao J.; Qi X. Optimization of the conditions for copper-mediated N-arylation of heteroarylamines. Eur. J. Org. Chem., 2007:6084, 2007.

[85] Reddy G. S.; Muralidhar Reddy M.; Yadav J. S. Meshra, H. M;. Zinc mediated facile amide formation: Application to alkyl, aryl, heterocycle, carbohydrate and amino acids. Tetrahedron Lett., 39:4103, 1998.

[86] Lhiaubet-Valle V.; Sarabia Z.; Hernandez D.; Castell J. V.; Miranda M. A. In vitro studies on DNA-photosensitization by different drug stereoisomers. Toxicol. in Vitro, 17:651, 2003.

[87] Girotti A.W. Translocation as a means of disseminating lipid hydroperoxideinduced oxidative damage and effector action. Free Radic. Biol. Med., 44:956, 2008.

[88] Clare L. H.; Morgan P. E. ; Davies M. J. Quantification of protein modification by oxidants. Free Radic. Biol. Med., 46:965, 2009. 
[89] Jensen R.; Arnbjerg J.; Ogilby P. Reaction of singlet oxygen with tryptophan in proteins: A pronounced effect of the local environment on the reaction rate. J. Am. Chem. Soc., 134:9820, 2012.

[90] Pattison D.; Rahmanto A.; Davies M. Photo-oxidation of proteins. Photochem. Photobiol. Sci., 11:38, 2011.

[91] Lucymara F.; Agnez-Lima; J. T.A. Melo; A. E. Silva; et al. DNA damage by singlet oxygen and cellular protective mechanisms. Mutat. Res., 751:14, 2012 .

[92] Cadet J.; Douki T.; Ravanat J.L. Oxidatively generated base damage to cellular DNA. Free Radic. Biol. Med., 49:9, 2010.

[93] Scheinfeld N. S.; Chernoff K.; Ho M. K. D.; Liu Y. C. Drug-induced photoallergic and phototoxic reactions - an update. Expert Opin. Drug Safety, 13:321, 2014.

[94] Kruft B.; Greer A. Photosensitization reactions in vitro and in vivo. Photochem. Photobiol, 87:1204, 2011.

[95] Lovell J.; Liu T.; Chen J; Zheng G. Activatable photosensitizers for imaging and therapy. Chem Rev., 110:2839, 2010.

[96] Schweitzer C.; Schmidt R. Physical mechanisms of generation and deactivation of singlet oxygen. Chem. Rev., 103:1685, 2003.

[97] Baumler W.; Regensburger J.; Knak A.; Felgentrager A.; Maisch T. UVA and endogenous photosensitizers - the detection of singlet oxygen by its luminescence. Photochem. Photobiol. Sci., 11:107, 2011.

[98] Ogilby P. R. Singlet oxygen: there is indeed something new under the sun. Chem. Soc. Rev., 39:3181, 2010.

[99] Burns J.; Cooper W.; Ferry J. Methods for reactive oxygen species (ROS) detection in aqueous environments. Aquatic Sci., 74:683, 102012.

[100] Yu-Ying H.; Li-Jin J. Synthesis and EPR investigations of new aminated hypocrellin derivatives. Free Radic. Biol. Med., 28:1642, 2000.

[101] Kladna A.; Aboul-Enein H.; Kruk I. Enhancing effect of melatonin on chemiluminescence accompanying decomposition of hydrogen peroxide in the presence of copper. Free Radic. Biol. Med., 34:1544, 2003.

[102] Lhiaubet-Vallet V.; Paillous N.; Chouini-Lalanne N. Comparison of DNA damage photoinduced by ketoprofen, fenofibric acid and benzophenone via electron and energy transfer. Photochem. Photobiol., 74:670, 2001.

[103] Rahimipour S.; Palivan C.; Barbosa F.;. Chemical and photochemical electron transfer of new helianthrone derivatives: aspects of their photodynamic activity. J. Am. Chem. Soc., 125:1376, 2003. 
[104] Vendrell-Criado V.; Rodriguez-Muñiz G.; Cuquerella M.C.; Lhiaubet-Vallet V.; Miranda M. A. Photosensitization of DNA by 5-methyl-2-pyrimidone deoxyribonucleoside: (6-4) photoproduct as a possible Trojan horse. Angew. Chem. Int. Ed., 52:6341, 062013.

[105] Yuying H.; Jingyi A.; Lijin J. Effect of structural modifications on photosensitizing activities of hypocrellin dyes: EPR and spectrophotometric studies. Free Radic. Biol. Med., 26:1146, 1999.

[106] Nardi G.; Lhiaubet-Vallet V.; Leandro-Garcia P.; Miranda M.A. Potential phototoxicity of rosuvastatin mediated by its dihydrophenanthrene-like photoproduct. Chem. Res. Toxicol., 24:1779, 2011.

[107] Cohen S.; Parola A; Parsons G. Photoreduction by amines. Chem. Rev., 73:141, 1973.

[108] Cossy J.; Belotti D. Generation of ketyl radical anions by photoinduced electron transfer (PET) between ketones and amines. synthetic applications. Tetrahedron, 62:6459, 2006.

[109] Yoon C.; Mariano S. Mechanistic and synthetic aspects of amine enone single electron-transfer photochemistry. Acc. Chem. Res, 25:233, 1992.

[110] Abdel-Shafi A.; Wilkinson F. Charge transfer effects on the efficiency of singlet oxygen production following oxygen quenching of excited singlet and triplet states of aromatic hydrocarbons in acetonitrile. J. Phys. Chem. A, 104:5747, 2000 .

[111] Darmanyan A.; Foote C. Solvent effects on singlet oxygen yield from $\mathrm{n} \pi^{*}$ and $\pi \pi^{*}$ triplet carbonyl compounds. J. Phys. Chem., 97:5032, 051993.

[112] Limones-Herrero D.; Perez-Ruiz R.; Jimenez M. C.; Miranda M. A. Bypassing the energy barrier of homolytic photodehalogenation in chloroaromatics through self-quenching. Org. Lett., 15:1314, 032013.

[113] Oliveros E.; Suardi-Murasecco P. ; Aminian-Saghafi T.; Braun A.M.; Hansen H. 1H-phenalen-1-one: Photophysical properties and singlet-oxygen production. Helv. Chim. Acta, 74:79, 1991.

[114] Brede O.; Beckert D.; Windolph C.; Gottinger H. A. One-electron oxidation of sterically hindered amines to nitroxyl radicals:intermediate amine radical cations, aminyl, A-aminoalkyl, and aminylperoxyl radicals. J. Phys. Chem. A, 102:1457, 1998.

[115] Qin Qin Z.; Schnabel W. Interaction of triplet-excited benzophenone with hindered amines and amino ethers: A laser flash photolysis study employing photoconductivity and light emission measurements. J. Photochem.Photobiol. A, 130:119, 2000. 
[116] Bortolus P.; Monti S.; Galiazzo G.; Gennari G. Complexation of aliphatic amines with carbazole in the $\mathrm{S}_{0}$ and $\mathrm{S}_{1}$ states: Solvent effect on the deactivation of the excited complex. Chem. Phys., 223:99, 1997.

[117] Pischel U.; Nau W. M. Switch-over in photochemical reaction mechanism from hydrogen abstraction to exciplex-induced quenching:interaction of triplet-excited versus singlet-excited acetone versus cumyloxyl radicals with amines. J. Am. Chem. Soc., 123:9727, 2001.

[118] Ciminale F.; Lopez L.; Farinola G.; Sportelli S.; Nacci A. Acid catalysis in the aminium hexachloroantimonate-induced cyclodimerization of 1-aryl-1phenylethylenes. Eur. J. Org. Chem., 2002:3850, 2002.

[119] Gottinger H. A.; Zubarev V. E.; Brede O. Low-temperature EPR study of the reaction of the 2,2,6,6-tetramethylpiperidyl radical with molecular oxygen. direct spectroscopic observation of an aminylperoxyl radical. J. Chem. Soc. Perkin Trans. 2, page 2167, 1997.

[120] Roberts J. R.; Ingold K. U. Kinetic applications or electron paramagnetic resonance spectroscopy. X. reactions of some alkylamino radicals in solution. J. Am. Chem. Soc., 95:3228, 1973.

[121] Faucitano A.; Buttafava A.; Martinotti F.; Bortolus P. First electron spin resonance identification of a nitrogen peroxy radical as intermediate in the photooxidation of 2,2,6,6-tetramethylpiperidine derivatives. J. Phys. Chem., 88:1187, 1984.

[122] Schmidt R.; Afshari E. Comment on "effect of solvent on the phosphorescence rate constant of singlet molecular oxygen". J. Phys. Chem., 94:4377, 1990.

[123] Barbierikova Z.; Mihalikova M.; Brezova V. Photoinduced oxidation of sterically hindered amines in acetonitrile solutions and titania suspensions (an EPR study). Photochem. Photobiol., 6:1442, 2012.

[124] Andrew J. W.; Drouin L.; Compton R. G. Voltammetric reduction of perinaphthenone in aqueous and non-aqueous media: An electrochemical esr investigation. J. Electroanal. Chem., 589:128, 2006.

[125] Abad S.; Vaya I.; Jimenez M.C.; Pischel U.; Miranda M.A. Diastereodifferentiation of novel naphthalene dyads by fluorescence quenching and excimer formation. ChemPhysChem, 7:2175, 2006. 


\section{List of Figures}

1.1 The Jablonski diagram, where $h \nu$ : absortion, $-h \nu$ ': fluorescence, $-h \nu$ ": phosphorescence, IC: internal conversion, ISC: intersystem crossing. . . . . . . . . . . . . . . . 3

1.2 Mechanistic pathways involved in the photosensitization processes of biomolecules. Figure redrawn from reference [4] . . . . . . . 5

1.3 One electron oxidation of guanine nucleobase. $\mathrm{R}$ is the DNA chain . 6

1.4 Photooxidation of methyl linoleate . . . . . . . . . . . . . 6

1.5 Reaction of ${ }^{1} \mathrm{O}_{2}$ with Trp. $\mathrm{R}$ is the protein chain . . . . . . . . . 6

1.6 Main oxidation product produced by the reaction of ${ }^{1} \mathrm{O}_{2}$ with the guanine moiety. . . . . . . . . . . . . . . 7

1.7 Step of the biosynthesis of isoprenoids and sterols inhibited by statins: the four-electron reductive deacylation of HMG-CoA to coenzyme A and mevalonate. . . . . . . . . . . . . . . . . . 9 9

1.8 Structures of Lovastatin, Fluvastatin and Fluvastatin photoproduct . 9

1.9 Photosensitized protein oxidation by fluvastatin (grey) and its photoproduct (white) at $11 \mathrm{~J} \mathrm{~cm}^{-2} \mathrm{UVA}$, and $10 \mu \mathrm{M}$ of photosensitizer, monitored as carbonyl content. Figure from reference [20] . . . . . . 10

1.10 Structures of ATV and ppATV . . . . . . . . . . . . . . 11

1.11 Transient absorption spectrum of a deaerated methanolic solution of ppATV after laser pulse from 5 to $50 \mu \mathrm{s}$. Inset: Normalized decay monitored at $450 \mathrm{~nm}$ of the transient obtained with nitrogenbubbled (black line) or aerated (gray line) solutions of ppATV. Adapted from reference $[22] \ldots \ldots$. . . . . . . . . . . . . 11

1.12 Time-dependent formation of TEMPO upon irradiation of aerated solutions of TEMP in the presence of $\operatorname{ATV}(\triangle)$ or $\operatorname{ppATV}(\mathbf{\square})$. Inset: TEMPO signals obtained after $30 \mathrm{~min}$ of irradiation of a solution of ATV (gray line) and ppATV(black line).Adapted from reference $[22] \ldots \ldots \ldots \ldots 1 . \ldots \ldots$

1.13 Tryptophan photodegradation monitored as function of irradiation time: tryptophan alone $(\boldsymbol{\square})$, tryptophan and ppATV in water $(\bullet)$, and tryptophan and ppATV in deuterium oxide as solvent $(\square)$. Adapted from reference $[22] \ldots \ldots$. . . . . . . . . . . . . 12

1.14 Photophysical and photochemical pathways of carprofen. Figure redrawn from reference $[23] \ldots \ldots$. . . . . . . . . . 13 
1.15 Transient absortion spectra of a nitrogen-saturated PBS solution of CRP measured after $150 \mathrm{~ns}$ (A) and $2000 \mathrm{~ns}$ (B). Plot C is the difference (A-B) to observe better CRP triplet and e-(aq). Adapted

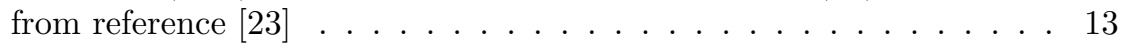

1.16 Photoperoxidation of linoleic acid sensitized by $\mathbf{C R P}(\bullet), \mathbf{p p C R P}$ $(\square)$, and tiaprofenic acid $(\square)$. Adapted from reference $[23]$. . . . . 14

1.17 Photohemolysis of RBC sensitized by CRP $(\bullet)$ and ppCRP ( $\square)$. Adapted from reference $[23] \ldots \ldots$. . . . . . . . . . 14

1.18 Photochemical pathways of diclofenac and its photoproduct. Figure redrawn from reference $[28] \ldots \ldots \ldots$. . . . . . . . . 15

1.19 Transient absorption spectra of a nitrogen-saturated ethanol solution of ppDCF measured at 200 and $900 \mathrm{~ns}$ after the pulse. Adapted from reference $[28] \ldots \ldots \ldots \ldots$. . . . . . . . . . . . . . . . .

1.20 Photoperoxidation of linoleic acid sensitized by ppDCF (०) and carprofen $(\triangle)$. Adapted from reference $[28] \ldots \ldots$. . . . . . . 16

1.21 Photohemolysis of RBC sensitized by DCF ( $\square$ ), ppDCF (o), other photoproduct $(\triangle)$, and carprofen $(\nabla)$. Adapted from reference $[28]$. 16

3.1 Structures of rosuvastatin (RSV) and its photoproducts . . . . . . . 20

3.2 Up, general intramolecular photocyclization of 2-vinylbiphenyl-like compound to yield dihydrophenanthrene. Bottom, transient absorption spectra of 1-(o-diphenyl)-1-phenylethylene. Dotted line: triplet absorption. Full line: cyclic intermediate. Figure adapted from ref [31]

3.3 Absorption spectra of RSV $4.8 \times 10^{-5} \mathrm{M}(\boldsymbol{\square})$ and ppRSV $1.5 \times$ $10^{-5}$ (o) in PBS. . . . . . . . . . . . . . . .

3.4 LFP at $308 \mathrm{~nm}$ excitation of $\mathbf{R S V}\left(4.8 \times 10^{-5} \mathrm{M}\right)$ in PBS, decays monitored at $400 \mathrm{~nm}$ : after the first LFP pulse (ש) and the second LFP pulse (o).

3.5 Transient absorption spectra of $\mathbf{R S V}\left(4.8 \times 10^{-5} \mathrm{M}\right)$ in PBS solution, recorded using a fresh solution for each laser pulse $(\mathrm{Xe} / \mathrm{Cl}$ excimer, $308 \mathrm{~nm}$ excitation).

3.6 Fluorescence excitation (o, $\lambda_{e m}=376 \mathrm{~nm}$ ) and emission ( $\boldsymbol{\square}, \lambda_{\text {exc }}$ $=314 \mathrm{~nm}$ ) of ppRSV in acetonitrile at $295 \mathrm{~K}$. Phosphorescence emission spectrum in EtOH at $77 \mathrm{~K}\left(\triangle, \lambda_{e x c}=312 \mathrm{~nm}\right)$.

3.7 Transient spectrum (from 2 to $20 \mu \mathrm{s}$ ) of triplet - triplet transition obtained for a degassed acetonitrile solution of ppRSV $\left(3.3 \times 10^{-5}\right.$ M) after $308 \mathrm{~nm}$ laser excitation. . . . . . . . . . . . .

3.8 LFP at $308 \mathrm{~nm}$ excitation of ppRSV $\left(3.3 \times 10^{-5} \mathrm{M}\right)$ in deaerated ACN, transient decay monitored at $400 \mathrm{~nm}$ without (ם)and in the presence of increasing concentration of $\beta$-carotene (from 0 to $2.0 \times 10^{-5}$ $\mathrm{M})$. Inset: Transient absorption spectrum (from 1 to $5 \mu \mathrm{s}$ ) of triplettriplet transition obtained for a degassed acetonitrile solution of ppRSV $\left(3.3 \times 10^{-5} \mathrm{M}\right)$ and $\beta$-carotene $\left(2.0 \times 10^{-5} \mathrm{M}\right)$ after $308 \mathrm{~nm}$ laser excitation. 
3.9 LFP at $355 \mathrm{~nm}$ excitation. Decays of xanthone $\left(6.6 \times 10^{-5} \mathrm{M}\right.$ in deaerated acetonitrile) monitored at $630 \mathrm{~nm}$, in the presence of increasing concentration of ppRSV (from 0 to $6.6 \times 10^{-5} \mathrm{M}$ ). Inset: Stern-Volmer plot. . . . . . . . . . . . . . . 25

3.10 TEMPO signals obtained by irradiation of a methanolic solution of TEMP $(10 \mathrm{mM})$ and ppRSV $\left(3.3 \times 10^{-5} \mathrm{M}\right)$ : without irradiation $(\square)$ and after $5(\mathbf{\Delta})$ and 7 (०) min of irradiation . . . . . . . . 25

3.11 Summary of all reactions involved in rosuvastatin phototoxicity promoted by its photoproduct. . . . . . . . . . . . . . . 26

$3.12 \mathrm{LFP}$ at $308 \mathrm{~nm}$ excitation of ppRSV $\left(3.3 \times 10^{-5} \mathrm{M}\right)$ in deaerated PBS, transient decay monitored at $400 \mathrm{~nm}$ without $(\boldsymbol{\square})$ and with $10^{-3} \mathrm{M}$ Thd (o). Inset: Stern - Volmer plot. . . . . . . . . . . . . .

3.13 Schematic representation of photosensitized formation of thymidine dimer. . . . . . . . . . . . . . . .

$3.14 \mathrm{LFP}$ at $308 \mathrm{~nm}$ excitation of ppRSV $\left(3.3 \times 10^{-5} \mathrm{M}\right)$ in deaerated PBS, transient decay monitored at $400 \mathrm{~nm}$ without $(\boldsymbol{\square})$ and with $5 \times 10^{-6} \mathrm{M}(\triangle)$ Trp. Inset: Transient absorption spectrum of ppRSV in the presence of $1.8 \times 10^{-5} \mathrm{M}$ Trp registered 2, 10, $60 \mu$ s after the laser pulse.

3.15 (A) $1.8 \times 10^{-5}$ M Tryptophan fluorescence emission $\left(\lambda_{\text {exc }}=282 \mathrm{~nm}\right)$ with an equimolar concentration of ppRSV, recorded at increasing irradiation time. (B) Tryptophan photodegradation. Normalized emission at $\lambda_{e m}=353 \mathrm{~nm}$ monitored as a function of irradiation time: Trp alone in PBS (ם), and Trp in the presence of equimolar amounts of ppRSV $\left(2 \times 10^{-5} \mathrm{M}\right)$ in PBS (o) and in deuterium oxide as solvent $(\triangle) \ldots \ldots \ldots \ldots \ldots \ldots$

4.1 Structure of itraconazole $(\mathbf{1})$ and its photoproducts $\mathbf{2 - 4}$. . . . . . . . 34

4.2 Ergosterol synthesis pathway: cytochrome P450 14 $\alpha$-sterol demethylase is inhibited by 1

4.3 Absorption spectra of $\mathbf{1}$ in different solvents: $\mathrm{MeOH}$ (solid squares), acetonitrile (circles) and dichloromethane (triangles). . . . . . . . . 36

4.4 Normalized excitation spectra of $\mathbf{1}$ in $\mathrm{MeOH}$ (solid squares, $\lambda_{e m}=$ $376 \mathrm{~nm}$ ), fluorescence emission (circles, $\lambda_{e x c}=262 \mathrm{~nm}$ ). Phosphorescence emission spectrum in EtOH at $77 \mathrm{~K}$ (triangles, $\lambda_{e x c}=262$ $\mathrm{nm})$.

4.5 HPLC pattern obtained during UVB irradiation of 1 in acetonitrile. The peaks are marked with the numbers corresponding to the struc-

4.6 ${ }^{1} \mathrm{H}-\mathrm{NMR}$ differences between $\mathbf{1}$ and $\mathbf{2}$ : disappearance of triazole hydrogen signal at $8.40 \mathrm{ppm}$ and shift of the phenyl hydrogens . . . 38

$4.7{ }^{1} \mathrm{H}-\mathrm{NMR}$ differences between $\mathbf{1}$ and 3: Substitution of chlorine atom at second position of phenyl ring by a hydrogen atom leads to a more symmetric distribution of the phenyl signals. 
$4.8{ }^{1} \mathrm{H}-\mathrm{NMR}$ differences between 1 and 4: Substitution of chlorine atom at position 4 of the phenyl ring by a hydrogen atom is revealed by the appearance of doublets with hyperfine structure. . . . . . . . . 39

4.9 Relative areas of $\mathbf{1}$ and its photoproducts $\mathbf{2 , 3}, \mathbf{4}$ determined by HPLC (monitored at $254 \mathrm{~nm}$ ), plotted as a function of reaction time. Irradiations were performed in ACN under UVB irradiation. . . . . . . 40

4.10 (A) Mechanistic scheme for photodecomposition of $\mathbf{1}$ in different media. (B) Potential photoreactivity of $\mathbf{1}$ with biomolecules. . . . . 40

4.11 Relative areas of $\mathbf{1}$ and its photoproducts $\mathbf{2 , 3}$ and $\mathbf{4}$ determined by HPLC (monitored at $254 \mathrm{~nm}$ ), plotted as a function of reaction time. Irradiations were performed in EtOH under UVB irradiation. . . . 41

4.12 Dyad KP- $\alpha$ Ch and formation of photoproduct upon photolysis. . . 42

4.13 Dyad CRP-Trp. . . . . . . . . . . . . . . . . . 43

4.14 Photoreactivity of the model dyad 5. . . . . . . . . . . . . . . 43

4.15 DEPT ${ }^{13} \mathrm{C}$ NMR of 5 and $\mathbf{6}$ : disappearance of $\mathrm{CH}$ signal due the cyclization at the $\mathrm{C} 2$ position of indole moiety. . . . . . . . . . . . 44

5.1 Structure of IMT and some of its potentially photoactive substructures . . . . . . . . . . . . . . . . . 5 50

5.2 Agarose gel electrophoresis of supercoiled DNA (pBR322, $20 \mu \mathrm{M}$ ) irradiated for $0-30 \mathrm{~min}$ alone and in the presence of $\mathbf{1}, \mathbf{2}$ or IMT

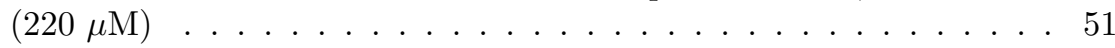

5.3 UV absorption spectra of IMT (black) and compounds $\mathbf{1}$ (green) and 2 (red) in acetonitrile . . . . . . . . . . . . . . . . 52

5.4 Fluorescence emission (full line) and excitation (dotted line) spectra of compound $\mathbf{1}$ at $\lambda_{\text {exc }}=280 \mathrm{~nm}(\mathrm{~A})$ and compound $\mathbf{2}$ at $\lambda_{\text {exc }}=328$ $\mathrm{nm}(\mathrm{B})$ in acetonitrile solution . . . . . . . . . . . . 53

5.5 (A) Transient absorption spectra of compound $\mathbf{1}$ in deaerated acetonitrile obtained at different times after the laser pulse at $308 \mathrm{~nm}$. (B) Transient absorption spectra $0.8 \mu$ s after the laser pulse of $\mathbf{1}$, in the presence of $1500 \mu \mathrm{M}$ biphenyl (black) or $33 \mu \mathrm{M} \beta$-carotene (blue). (C) Decay at $700 \mathrm{~nm}$ and growth at $520 \mathrm{~nm}$ for a solution of 1 in the presence of $\beta$-carotene $(33 \mu \mathrm{M}) \ldots \ldots \ldots \ldots$

5.6 (A) Transient absorption spectra of $\mathbf{2}$ in $\mathrm{N}_{2}$-bubbled acetonitrile at different times after $308 \mathrm{~nm}$ laser excitation. (B) Decays of xanthone triplet excited state monitored at $612 \mathrm{~nm}$ in the presence of increasing amounts of 2 (from 0 to $84 \mu \mathrm{M}$ ). Inset: Corresponding Stern-Volmer plot. (C) Growth of the $520 \mathrm{~nm}$ signal upon quenching of $\mathbf{3}^{\mathbf{3}}$ by $13 \mu \mathrm{M} \beta \mathbf{C}$. Inset: spectra obtained after 0.40 (red)

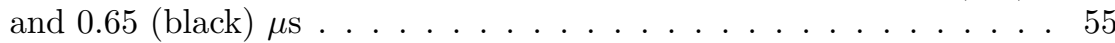

5.7 (A) Structure of compound $\mathbf{3}$ and its relationship to IMT. (B) Decays of ${ }^{\mathbf{3}} \mathbf{2}^{*}$ monitored at $420 \mathrm{~nm}$ in the presence of increasing amounts of $\mathbf{3}$ (from 0 to $23 \mu \mathrm{M}$ ). Inset: Corresponding Stern-Volmer plot 
6.1 Structure of the molecules involved in the study and EPR signal of TEMPO radical. . . . . . . . . . . . . . . .

6.2 Aerated ACN solution of $\mathbf{P N}$ (red), BP (blue), NP (green) and CBZ (cyano). (A) Intensity of TEMPO in EPR as a function of irradiation time at $280 \mathrm{~nm}$. In black, ACN solution of $50 \mathrm{mM}$ TEMP. (B) Initial intensity of ${ }^{1} \mathrm{O}_{2}$ TRNIR signal as a function of $266 \mathrm{~nm}$ laser energy. In black, solution of BP and $50 \mathrm{mM}$ TEMP. . . . . . .

6.3 Decay of ${ }^{1} \mathrm{O}_{2}$ at $1270 \mathrm{~nm}$ in aerated ACN solution of (A) BP, (B) PN with $0 \mathrm{mM}$ TEMP (black), $5 \mathrm{mM}$ TEMP (red), $50 \mathrm{mM}$ TEMP (blue). Incident $355 \mathrm{~nm}$ laser energy: $3.65 \mathrm{~mJ} /$ pulse, $\mathrm{Abs}_{355}=0.3$. .

6.4 (A) Steady state fluorescence spectra of $\mathbf{C B Z}$ in aerated ACN solution with increasing amount of TEMP. $[\mathrm{CBZ}]=3.5 \times 10^{-5} \mathrm{M}, \lambda_{\text {ex }}=$ $331 \mathrm{~nm}$. [TEMP] = 0 (black), 10 (red), 50 (blue), $100 \mathrm{mM}$ (green). Inset: Decay of CBZ at $341 \mathrm{~nm}$ in aerated ACN solution with $0 \mathrm{mM}$ TEMP (black), $50 \mathrm{mM}$ TEMP (blue). (B) Steady state fluorescence spectra of NP in aerated ACN solution with increasing amount of TEMP. $[\mathrm{NP}]=2.3 \times 10^{-6} \mathrm{M}, \lambda_{e x}=278 \mathrm{~nm} .[\mathrm{TEMP}]=0$ (black), 10 (red), $50 \mathrm{mM}$ (blue). Inset: Decay of $\mathbf{N P}$ at $320 \mathrm{~nm}$ in aerated ACN solution with $0 \mathrm{mM}$ TEMP (black), $50 \mathrm{mM}$ of TEMP (blue).

6.5 Proposed mechanism for the electron tranfer oxidation of TEMP to TEMPO in the presence of molecular oxygen. . . . . . . . . . .

6.6 (A) Emission of an aerated ACN solution of $\mathbf{R B}$ alone (black) or in the presence of $100 \mathrm{mM}$ TEMP (blue). $[\mathrm{RB}]=4 \times 10^{-6} \mathrm{M}, \lambda_{e x}=$ $560 \mathrm{~nm}$. Inset: Stern-Volmer plot obtained from time-resolved measurements of RB in the presence of increasing amounts of TEMP $\left(\lambda_{e x}=560 \mathrm{~nm}, \lambda_{e m}=573 \mathrm{~nm}\right)$. (B) T-T absorption decays monitored at $620 \mathrm{~nm}\left(\lambda_{e x}=532 \mathrm{~nm}\right)$ of argon-bubbled ACN solution of $\mathbf{R B}\left(3.3 \times 10^{-5} \mathrm{M}\right)$ alone (black) or in the presence of $100 \mathrm{mM}$ TEMP (blue). (C) Area of TEMPO signal in EPR as a function of irradiation time at $280 \mathrm{~nm}, \mathrm{~A}_{280}=0.4 \ldots \ldots \ldots 66$

C.1 Normalized T-T absorption decay $\left(\lambda_{e x}=355 \mathrm{~nm}\right.$, monitored at 480 $\mathrm{nm})$ of argon-bubbled ACN solution of PN $\left(2.1 \times 10^{-5} \mathrm{M}\right)$ with increasing amount of TEMP: 0 (black), 10 (red), 50 (blue) mM. Inset: plot of the triplet decay rate constant vs. concentration of quencher. 107

C.2 Normalized T-T absorption decay $\left(\lambda_{e x}=355 \mathrm{~nm}\right.$, monitored at 530 $\mathrm{nm})$ of argon-bubbled ACN solution of BP $\left(3.1 \times 10^{-3} \mathrm{M}\right)$ with increasing amount of TEMP 0 (black), 0.2 (red), 0.6 (blue), 1 (purple) $\mathrm{mM}$. Inset: plot of triplet decay rate constant vs. concentration of quencher . . . . . . . . . . . . . . . . . . . 108

C.3 T-T absorption decay $\left(\lambda_{e x}=266 \mathrm{~nm}\right.$, monitored at $415 \mathrm{~nm}$ ) of argon-bubbled ACN solution of NP $\left(7.1 \times 10^{-3} \mathrm{M}\right)$ with increasing amount of TEMP: 0 (black), 10 (red), 50 (blue) mM. . . . . . . . . . 108

C.4 Stern-Volmer plots of CBZ $\left(3.5 \times 10^{-5} \mathrm{M}\right)$ in the presence of TEMP obtained from steady-state (top) and time-resolved fluorescence (bottom) experiments. . . . . . . . . . . . . . . . 109 
C.5 Stern-Volmer plots of NP $\left(2.3 \times 10^{-6} \mathrm{M}\right)$ in the presence of TEMP obtained from steady-state (top) and time-resolved fluorescence (bottom) experiments. . . . . . . . . . . . . . . . . . 109

C.6 UV absorption spectra of an acetonitrile solution of BAHA $(100 \mu \mathrm{M})$ in the absence (black) and in the presence (red) of a stoichiometric amount of TEMP. . . . . . . . . . . . . . . . . . . . 110

C.7 TEMPO/EPR signals obtained for ACN solution of TEMP (50 mM) without (dotted line) and in the presence of $5 \mathrm{mM}$ BAHA under aerobic (red line) or anaerobic conditions (black line). . . . . . . . 110

The picture of the cover is a cutting from "El balandrito" of Joaquin Sorolla ( Museo Sorolla, Madrid (C) Ministerio de Cultura) 


\section{List of Tables}

1.1 Effect of Lovastatin (alone or with protectors) on the 24h UVAinduced photocytotoxicity in cultured human cell. Table modified from $\operatorname{ref}[18] \ldots \ldots \ldots \ldots$

3.1 Photophysical properties of ppRSV in different solvents . . . . . . . 24

4.1 Photophysical properties of $\mathbf{1}$ in different solvents . . . . . . . . . . . 36

6.1 Singlet oxygen quantum yield of each photosensitizer . . . . . . . . . 61 


\section{Acknowledgement}

Quizá sea el momento y lugar idóneo para, desde estas páginas, expresar mi enorme agradecimiento a todas aquellas personas que de alguna manera han hecho posible que esta tesis doctoral se haya llevado a cabo.

En primer lugar quiero agradecer a Miguel Ángel Miranda que me ofreciera en su día la posibilidad de trabajar en su grupo y que posteriormente aceptara dirigir el presente trabajo. Su apoyo, atención y consejo han sido permanentes durante todo el proceso en esta investigación, sin su dirección el desarrollo de este trabajo no hubiera sido posible. Personalmente, la lectura más importante que me llevo, tras todos estos años siendo un miembro más de su equipo de investigación, no ha sido en su esencia el logro de esta tesis doctoral, sino lo mucho que he aprendido de él acerca de la lógica y el método en las ciencias químicas, no ha sido únicamente mi tutor, sino que ha sido mi maestro.

A continuación, agradecer a Virginie Lhiaubet-Vallet la infinita paciencia que ha mostrado conmigo, no fui un estudiante ejemplar en lo que concierne a la rutina y a las formalidades, mi carácter disperso y altamente atraído por las curiosidades científicas y las menos científicas seguramente hayan desconcertado a esta excelente profesional en más de una ocasión. Aprovecho este momento para hacérselo saber, me llevo de ella el ejemplo de ser un investigador constante y sereno, estas cualidades la definen.

Cómo no aprovechar esta oportunidad para agradecer a todos mis compañeros de laboratorio de estos seis años atrás, la capacidad de tolerancia que me han mostrado, principalmente por mi manera poco ortodoxa de trabajar. Por orden cronológico nombrar a Sara, Cecilia, Jhoanes, Cleo, Jana, Mireia, Edurne, Sonia, Miguel, Patri, Paco, Marisa, Chelo, Inma, Fabrizio, Filo, Maya, Francesco, Pierre, Alexandra, Gemma, Vicky, Paula, Isa, Ana y en el departamento de química nombrar a Pavel, Raúl, Carlos, Nacho, Paula, Rafa, Dani, Neus, Susana y Chelo.

Finalmente, me gustaría agradecerles a todas aquellas personas que hacen del ITQ un lugar excepcional para formarse y trabajar. Sois muchos los que en estos años he tenido la ocasión de cruzarme en vuestros caminos, desde los perseverantes investigadores que han levantado nuestro instituto hasta cada compañero procedente de cualquier rincón del mundo. Mi agradecimiento va dirigido a cada persona que se ha detenido, aunque fuera por un solo instante, a conversar conmigo y que ha hecho posible compartir con él un momento común de mi vida aquí en Valencia.

Siamo finalmente arrivati ai ringraziamenti in italiano. Oltre alla dedica, i miei maggiori ringraziamenti vanno alla mia familia. Non è stato facile decidere di stare lontani per sei anni, per fortuna la distanza temporale di Valencia è facilmente superabile. Un ringraziamento enorme va ai miei amici Valerio, Gustavo, Mario, Priscilla, Marco, Boris, Ivan, Jaime, Carlos, Alex e Jessy. In questi anni ognuno di voi ha apportato un granellino di sabbia a questa opera. Un grazie speciale a Merche, l'ultima spinta è stata importante. A tutti chiedo un poco di pazienza, la prossima avventura non tarderà ad arrivare. 